\title{
The whiteflies (Hemiptera: Aleyrodidae) of Europe and the Mediterranean Basin
}

\author{
J.H. Martin ${ }^{1 *}$, D. Mifsud ${ }^{2}$ and C. Rapisarda ${ }^{3}$ \\ ${ }^{1}$ Department of Entomology, The Natural History Museum, Cromwell \\ Road, London, SW7 5BD, UK: ${ }^{2}$ Naturhistorische Museum Basel, \\ Augustinergasse 2, 4001 Basel, Switzerland: ${ }^{3}$ Dipartimento di Scienze e \\ Tecnologie Fitosanitarie, Università degli Studi, Via Valdisavoia 5, 95123 \\ Catania, Italy
}

\begin{abstract}
The whitefly fauna of Europe and the Mediterranean Basin comprises 56 species that are considered to be native or naturalized, accommodated within 25 genera. Presented here are a check-list, an identification key to puparia, and a brief account of each species including its distribution and host-plant range. The puparium of each species is illustrated. One new nomenclatural combination (Aleuroclava similis, from Aleurotuberculatus) and two new synonymies (Parudamoselis kesselyaki with Ceraleurodicus varus, Asterobemisia nigrini with $A$. paveli) are proposed. Three nominal species (Aleurodes capreae, A. fraxini, and Aleyrodes campanulae) are here treated as nomina dubia. Species which, in the study area, have only been recorded from glasshouses are discussed. Four additional species, not yet recorded from the region, are included in the discussion, two of them because a particular quarantine risk is perceived and two because they are notifiable pests in European Union quarantine legislation.
\end{abstract}

\section{Introduction}

In recent years, whitefly pests have become a major problem for agriculturalists, almost worldwide. Although a mainly tropical group, injurious species are to be found in all warmer parts of the world and several are serious pests in glasshouses in temperate areas. Throughout the 20th century, species like Bemisia tabaci (Gennadius) and Trialeurodes vaporariorum (Westwood) have been notorious as pests of field crops in warmer climes, and of crops under glass or polythene. The emergence of destructive biotypes, particularly of B. tabaci, has led to increased resources being expended on the study of these insects.

Recently, an increasing problem has been the sudden economic impact caused by previously little-known whitefly species becoming established in new geographical areas. The most notorious of these is undoubtedly Aleurodicus dispersus Russell, the so-called 'spiralling whitefly', which is now

*Fax: (0)20 79425229

E-mail: jhm@nhm.ac.uk found in the Canary Islands and Madeira, with close links to the important agricultural area of the Mediterranean Basin.

With the number of whitefly pest incursions increasing, identification guides to the whiteflies of specified geographical areas become especially important. This is not only to enable the accurate naming of native species discovered causing problems, but also to increase the chances of early detection of newly introduced species. Mound \& Halsey (1978) provided a comprehensive catalogue of whiteflies worldwide, including host plant records and distributional data. Subsequently, there have been a number of publications dealing with aspects of systematics and local faunistics of whiteflies in Europe and in the Mediterranean area (see Survey of records in literature and collections). However, there has been no account of the group across the whole region, nor any identification guide.

Discussions at the first meeting of the European Whitefly Studies Network (an EC-funded Concerted Action, EWSN FAIR6 CT98-4303), held in Norwich, UK, 3-7 May 1999) pinpointed the lack of any ready means, for agricultural and quarantine staff or other non-specialists, to identify 
whiteflies in Europe. It was also noted that there was no definitive list of the whitefly species present. The authors determined to compile an up-to-date check-list of European whiteflies, as a preliminary step towards rectifying the situation. It was soon realized, however, that this check-list project could be much enhanced by amalgamating it with work that had already started on the provision of an identification guide to the whiteflies of the Mediterranean countries (Rapisarda et al., 1996). The result, presented here, is a check-list, account and identification guide to the whitefly fauna of the Mediterranean Region, combined with Europe to the west of the Federation of Independent States (as most of the countries of the former USSR are now known). The area considered here has a limited fauna of only 56 species which are considered to be native or naturalized. In addition to these 56 species two others, Aleurodicus dispersus Russell and Lecanoideus floccissimus Martin, Hernández-Suárez \& Carnero are included in the key because both are of considerable economic concern in the Canary Islands (Martin et al., 1997; Hernández-Suárez et al., 1997) and undoubtedly represent a quarantine risk in the Mediterranean area. Two species of Aleurocanthus, A. spiniferus (Quaintance) and A. woglumi Ashby, are also discussed here in the absence of European-Mediterranean records, because both are listed as pests officially considered to be at high risk of future introduction to the European Union (Smith et al., 1997).

\section{The Aleyrodidae}

Whiteflies belong to the order Hemiptera and comprise a single superfamily, Aleyrodoidea, within the suborder Sternorrhyncha. They are all placed in a single family, Aleyrodidae, and are small sap-sucking insects whose adults bear a remarkable superficial resemblance to tiny moths. Indeed, the European cabbage whitefly (Aleyrodes proletella) was initially described as a moth by Linnaeus (1758), and only subsequently recognized as hemipterous by Latreille (1795). The Aleyrodidae is the least speciose amongst the four groups of sternorrhynchous Hemiptera (at least as far as described species are concerned) by a wide margin, with around 1450 named species. This figure may be compared with over 6000 coccoids (Hodgson, 1994), 4400 aphidoids (Blackman \& Eastop, 1994), and 2500 psyllids (or jumping plant-lice) (Martin \& Hollis, 1992). However, recent tropical field collecting of whiteflies, in south-east Asia and Central America, indicates that only a particularly small proportion of species have been described (Martin, 1999).

The common name, 'whitefly', derives from the presence of secreted powdery wax which is preened over the body and wings by the adults of almost all species. Adult whiteflies are very small insects, most measuring $1-3 \mathrm{~mm}$ in body length Almost all adult whiteflies possess seven-segmented antennae and a fore-wing venation that is reduced to a simple or once-branched major vein $\left(R+R_{s}\right)$, with $R_{1}$ variably developed (figured by Gill, 1990). A structure known as a 'vasiform orifice' is unique to aleyrodids, and comprises the anus, a 'lingula' which ejects excreta, and an 'operculum' which partially or wholly covers the orifice itself (see fig. $28 \mathrm{~b}$, and annotated in fig. 2). The vasiform orifice is present in all larval stages, as well in the adults.

The whitefly life-cycle is unusual and may be compared and contrasted with some aspects of both the Psylloidea and Coccoidea. As with psylloids, adult whiteflies of both sexes possess a feeding rostrum and are four-winged and fully mobile, whereas adult coccoids are either wingless and neotenic (females) or lack mouthparts and possess just two wings if wings are present (males). Reproduction in whiteflies is usually sexual, occasionally parthenogenetic. Whitefly eggs are always laid onto the plant surface, as is the case with Psylloidea. In contrast, many Coccoidea lay eggs into egg sacs from which first-instar crawlers emerge onto the plant, sometimes giving an impression of viviparity. As with all Sternorrhyncha, first-instar whitefly larvae are mobile and can walk a short distance to locate suitable feeding sites. Once the first moult has taken place, however, the remaining three larval instars are sessile and individuals are unable to relocate themselves if feeding conditions deteriorate: this is similar to the immobility of many immature coccoids, but unlike most psylloids whose larval and nymphal stages are mobile unless gall-dwelling. The final whitefly larval stage is usually termed a 'puparium', a name which reflects the extreme morphological difference between this stage and the winged adults, whose emergence is facilitated by the rupturing of lines of weakness which are termed the 'transverse and longitudinal moulting sutures' (see fig. 2). The vacated puparium is often described as a 'pupal case'.

Female whiteflies usually deposit their eggs on the lower surfaces of leaves and the eggs of many species are laid in partial or complete circles, as the insect rotates about her rostrum while continuing to feed. Some species, particularly members of the subfamily Aleurodicinae, will oviposit on other surfaces such as fruits, and a few whitefly species habitually develop on the upper surfaces of leaves (e.g. Aleurolobus olivinus (Silvestri)), whilst others readily develop on both surfaces of leaves. Detailed accounts of whitefly biology and morphology were provided by Dobreanu \& Manolache (1969) and by Gill (1990).

Amongst the Sternorrhyncha, whiteflies appear to be a recently evolved group, with the oldest known fossil remains (not recognizably belonging to one of the two modern subfamilies) being from Lebanese amber from the Lower Cretaceous, 135 million years ago (Schlee, 1970). Material recognizable as belonging to the two present day subfamilies is known only from even more recent material: the Aleyrodinae in Baltic amber of 55 million years vintage (Palaeocene), and the Aleurodicinae from Burmese amber from 45-20 million years ago (Eocene through to Miocene). Whiteflies with modern affinities are thus known from a period during which angiosperm plants underwent great diversification (Campbell et al., 1994, 1996). Few present-day whiteflies feed on non-angiosperm hosts and the few species that habitually feed on ferns, and on 'fern allies' (terminology of Brummit, 1992) such as Selaginella (Mound et al., 1994), are very much exceptions to the rule. The great majority of whiteflies in existence today colonize only dicotyledonous angiosperms and a smaller, but significant, number feed on monocots, particularly grasses and palms. There is a solitary record of a whitefly feeding on a gymnosperm, involving the highly polyphagous Trialeurodes vaporariorum on a cycad, Dioon spinulosum.

The systematics of both whitefly subfamilies is currently based almost entirely on the puparial stage, and adults in isolation can be identified only rarely. This situation has arisen, in part, because puparia are often discovered in the absence of adult insects (see below). Unfortunately for systematists, whitefly puparia are notorious for displaying variation induced by, particularly, the physical characteris- 
tics of leaf surfaces, as indicated by Russell (1948) and subsequently demonstrated experimentally by Mound (1963). The phenomenon of puparial variation has become particularly well known amongst certain polyphagous species, notably species of Bemisia and Trialeurodes. In contrast, puparia of the polyphagous Aleurodicus dispersus display no such variation. Amongst some whitefly species with narrower host ranges, there is sufficient evidence of variation (for example, see discussion of Dialeurodes setiger (Goux) and D. citri (Ashmead)) for systematists to be cautious before regarding visible differences as specific. Where puparia develop on both surfaces of leaves, the differing characteristics of the upper and lower leaf surfaces may also induce such variation on a single plant (e.g. Aleuroviggianus polymorphus Bink-Moenen). There is, thus, a situation where major characters may be of limited taxonomic significance because of their variability within species, and aleyrodid systematists need to be alert to this problem. With such problems of variation in the puparial stage, the future of whitefly systematics undoubtedly lies in the concurrent use of both puparial and adult characterisics (Bink-Moenen \& Mound, 1990), and this approach has been particularly effectively used by Bink-Moenen (1992). Adult characters have been used with most success in the least speciose subfamily, Aleurodicinae, but a fundamental appraisal is much needed before adults are likely to be used more widely in whitefly systematics. The use of modern molecular techniques also promises to assist our understanding of the systematics of this insect group.

As well as displaying the variation discussed above, many aleyrodids also exhibit puparial sexual dimorphism, which usually manifests itself as male puparia being consistently smaller than those of females in the same colony. Other sexual differences are uncommon but, in addition to their smaller size, male puparia of species of Aleurocanthus have fewer dorsal glandular spines than those of females: in some other groups (e.g. some species of Aleurolobus) the antennae of male puparia are distinctly longer than those of females. In species without size dimorphism, sex-determination of individual puparia is not usually possible even though Russell (1948) reported that a tiny invagination, or 'bifid $\mathrm{sac}^{\prime}$ ', is present between the posterior abdominal spiracles of male puparia: this was discussed by Martin (1999). Instead of sexual dimorphism, a few temperate species exhibit distinct seasonal dimorphism, with puparia of summer generation(s) and overwintering puparia being markedly different (see comments on Aleurochiton and figure pairs $5 / 6$ and $7 / 8$ ).

With the exception of continuously breeding species, which tend to be polyphagous on herbaceous plants (and hence often pests), colonies of immature whiteflies are frequently discovered without associated adults, and this is one of the main reasons for the historical development of puparium-based taxonomy in this insect group. The frequent absence of adults appears likely to be because their emergence is often delayed until the host plant is physiologically suitable for the development of the next generation. The delay in adult emergence is often considerable, thus making the term 'puparium' particularly appropriate for the final larval stage.

\section{Economic importance of whiteflies}

Whiteflies feed via stylet mouthparts with which they pierce plant tissues and suck phloem sap. These insects often produce a large amount of sugar-rich excreta, whilst extracting sufficient protein-building amino acids from the sap to facilitate body growth. These excreta, termed 'honeydew', may support the growth of sooty mould on affected plants. Large infestations of whiteflies may thus adversely affect their hosts, both by causing excessive sap loss and through sooty mould interfering with photosynthesis. Although relatively few whiteflies are normally ant-attended, ants may be attracted to the honeydew of large colonies, and their presence may interfere with natural enemies of the whiteflies and of other pests in the vicinity. Secondary damage can be caused by some whitefly species, as copious production of woolly 'wax' secretions soils the plant canopies. Some whiteflies (particularly tropical species - J.H. Martin, personal observations) may also deform the leaves, which would be detrimental to the marketability of such plants, even if the whiteflies themselves have been eradicated. A major problem with whiteflies is that some species act as vectors of viral plant diseases, and such viruses themselves can cause a range of symptoms in crops (Bedford et al., 1994).

The list of cultivated plants colonized by whiteflies is extensive, but a great many records concern the relatively few highly polyphagous whitefly species (Mound \& Halsey, 1978; Carver \& Reid, 1996). In the geographical area covered by this study, whiteflies are primarily pests of vegetable crops (especially in greenhouses), citrus and ornamental plants.

A special note is needed on the importance of quarantine as a means of preventing the introduction of more whitefly species to Europe and the Mediterranean countries. With the ever-increasing worldwide trade in living plant material, whether as vegetables for human consumption or as ornamental plants, several whitefly species have already significantly extended their distributions and it may be expected that this trend will continue, despite the best efforts of port quarantine officials. This risk is probably underestimated by many, if not most, countries. The European Union has drawn up official lists of quarantine pests (Smith et al., 1997) which include two whitefly species, not yet recorded in Europe, which represent a particular risk to citrus (see discussion of Aleurocanthus spp.). However, no official mention is made of some other polyphagous whitefly pests that may easily cross the phytosanitary barriers of mainland Europe. Indeed, no mention is made of significant pest species that have already entered territories (the Macaronesian islands) that are politically part of the European Union (see accounts of Aleurodicus dispersus and Lecanoideus floccissimus).

\section{Materials, methods and terminology}

Slide-mounting of specimens is usually required for accurate identification, whether puparia or adults are to be examined. Techniques for slide preparation have been described by Bink (1979), Bink-Moenen (1983) and by Martin (1987, 1999), involving heating to macerate and remove wax; Pizza \& Porcelli (1993) described a method for cold maceration and de-waxing. The complex choice of mountants, and some of the associated problems, were discussed by Upton (1993) and by Brown (1997). The mountant chosen depends on factors such as the desired degree of permanence of preparations. When preparations are destined for reference collections, the authors favour use 
of Canada balsam or Euparal. Fortunately for agricultural entomologists, who require a rapid identification and are not concerned with the permanence of their preparations, quickmounts can often be made. These may be prepared using pupal cases from which adults have emerged, and the technique simply comprises carefully removing a few specimens from the leaf and placing them gently into almost any proprietary mountant. The microscope objective is then protected by covering the specimen(s) with a glass coverslip, and the slide-mount may be examined without any further procedures.

The most important tool to aid the identification of whitefly species, in the area of coverage, is the key to puparia herein. This key inevitably uses specialist whitefly puparial terminology, and this is annotated on fig. 2. Other publications that may be consulted for whitefly morphological terminology include Russell (1948), Dobreanu \& Manolache (1969), Bink-Moenen (1983) and Gill (1990). When on slides, the puparia of most taxa can be seen to have legs which are more-or-less curved, with the apical pads (often termed 'adhesion pads', but of uncertain function) of the middle and hind legs directed mesad, as in most illustrations here. The legs of second and third-instar larvae are rather triangular, with their apices directed laterad.

All the drawings reproduced here have previously appeared in other publications, and the original source is stated in the relevant figure caption, even where the originals were the work of one of the present authors. Although there is thus a considerable divergence of styles, and although very small setae are often not featured, it is not felt that this is an impediment to effectiveness in aiding identification. Scale bars are felt to be of limited use, and do not accompany the illustrations used here.

In individual species accounts, the quoted host-plant information refers to the whole geographical range of each whitefly species. Although many of these hosts will not be found growing in the area covered by this work, our intention is to indicate each whitefly's overall preferences, and it was felt to be impractical to attempt to distinguish between European-Mediterranean hosts and others. All host-plant familial and generic names use the system of Brummit (1992). Host records considered to be doubtful are quoted in square brackets and are discussed.

\section{The Europe-Mediterranean region defined}

The area included in this study lies west of the dashed line on the map (fig. 1) and is defined as follows: all countries of western and northern Europe, with the following included countries limiting the extent of coverage to the east - Finland, Estonia, Latvia, Lithuania, Poland, Slovakia, Hungary, Romania, Bulgaria; all countries directly bordering the Mediterranean Basin, including those in North Africa; Jordan is also included because of its close proximity to the Mediterranean. North Atlantic islands, such as Orkney, Shetland, Faroes, Iceland and Svalbard qualify for inclusion in this study, but the authors are not aware of any whitefly records to date.

Many published records refer to the former composite states of Czechoslovakia and Yugoslavia. In order to avoid the laborious checking of, often obscure, localities quoted in such records, these former country names are retained here, throughout the Distribution sections of the individual species accounts.

The whitefly fauna of Egypt is treated selectively. The Nile valley provides a narrow floristic corridor which enables several natives of the Ethiopian Region to approach the Mediterranean Basin, but Egyptian species are only included here if they are also recorded from elsewhere in the region. For more detail on the Egyptian whitefly fauna, Priesner \& Hosny $(1932,1934 a, b)$ and Bink-Moenen (1983) may be consulted.

Inclusion of the Canary Islands, Madeira and the Azores (collectively termed Macaronesia) in this work was considered. However, although politically part of Europe, these islands have a whitefly fauna that is substantially different to that found on the mainland, albeit with a considerable number of shared species. In particular, a great variety of morphological forms of the Bemisia afer-group have been discovered on many of the islands recently and detailed studies will be required to define their species limits. Work towards providing an account of the aleyrodids of the Macaronesian islands is currently in progress. A list of whitefly species currently known to occur in Macaronesia is presented here (appendix 1), for comparison with the main European-Mediterranean check-list.

The area covered by this study is very varied climatically and floristically. The Mediterranean basin is characterized by very warm summers, with its winters cool but certainly not cold at lower altitudes. Areas fringing the Atlantic seaboard, particularly the British Isles, the Benelux countries and parts of France, Portugal and Spain, are cool year-round, with abundant rainfall. Much of continental Europe, remote from coasts, is hot in summer and very cold in winter. With climate varying to such a degree, and with diverse soil types, the area enjoys a rich flora and may be divided into a wide range of vegetational zones, with about one hundred proposed by Polunin \& Walters (1985). It is perhaps surprising, therefore, that there are so few whitefly species found in the area under consideration. The answer appears to be that whiteflies are predominantly tropical, and thus are not particularly diverse even in the warmer parts of the Mediterranean and Middle East.

\section{Survey of records in literature and collections}

Mound \& Halsey (1978) published a complete catalogue of the world's whitefly fauna, with host-plant data. Data from collections made subsequently have been extracted directly from material in the collections of The Natural History Museum, London, UK (BMNH), the University of Catania, Italy, the Department of Agriculture, Malta, and the collection of Rosita Bink-Moenen (Netherlands). In particular, the BMNH collection contains significant holdings of post-1978 material from Corsica, Egypt, Israel, Malta, Morocco, Sicily, Spain and Turkey. Other additional country records have been obtained from a variety of published sources, major ones being the following:

Albania: Zahradnik (1991)

Austria: Zahradnik (1991)

former Czechoslovakia: Zahradnik (1985, 1987a,b, 1989b)

England: Martin (1978), Dolling \& Martin (1985)

Finland: Huldén (1986)

Germany: Zahradnik (1991) 


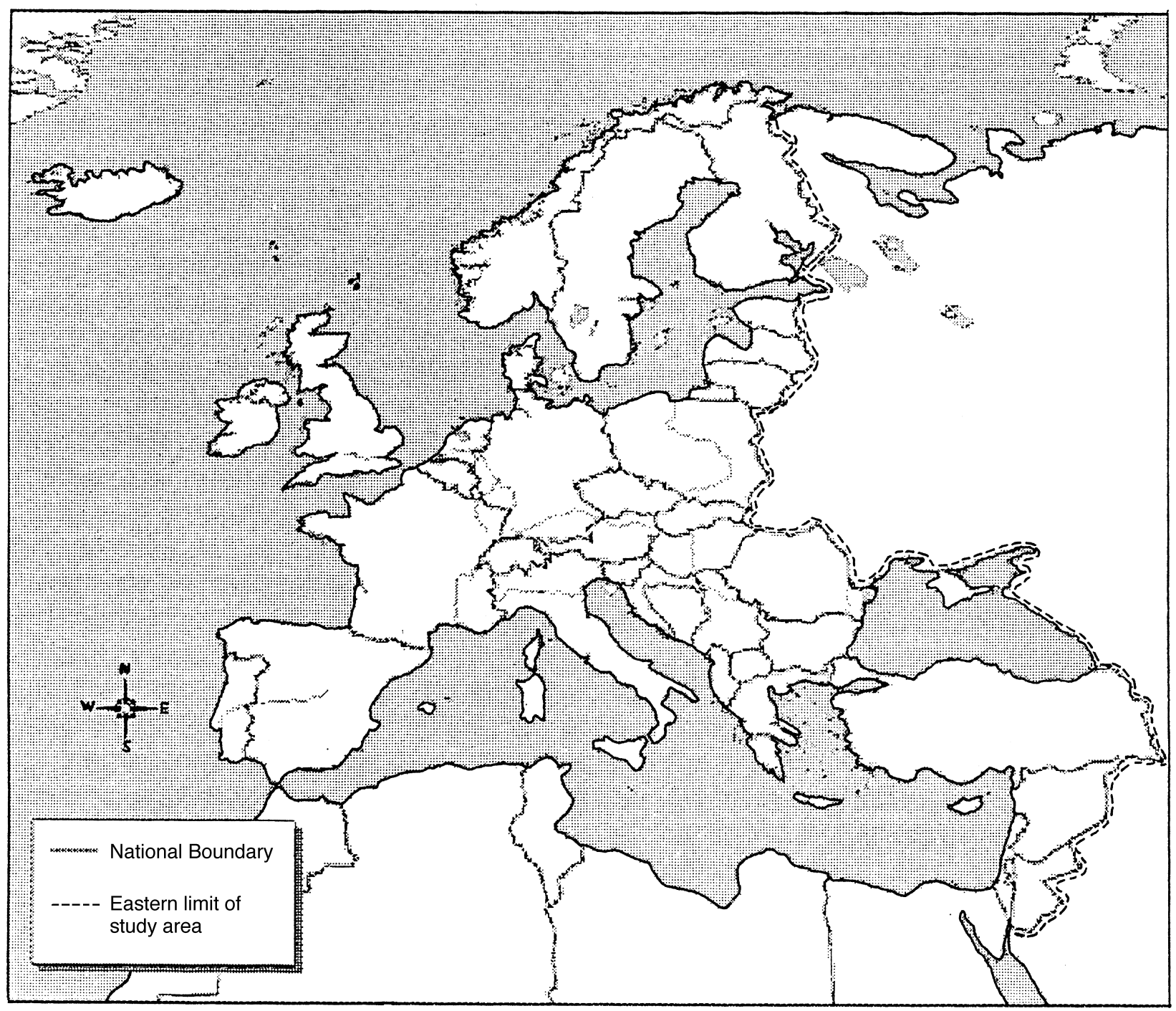

Fig. 1. Outline map of area covered by this study.

Hungary: Kozár et al. (1987), Kozár \& Bink-Moenen (1988), Zahradnik (1991)

Israel: Bink-Moenen \& Gerling (1992), Argov (1994)

Italy (including Sardinia and Sicily): Iaccarino (1981, 1982, 1985), Patti \& Rapisarda (1981), Rapisarda (1982, 1985, 1986, 1990, 1995, 1999), Rapisarda \& Patti (1983), Iaccarino \& Viggiani (1988), Longo et al. (1990), Rapisarda et al. (1990), Del Bene et al. (1991), Mifsud \& Palmeri (1996)

Lithuania: Zahradnik (1991)

Malta: Mifsud (1995), Mifsud \& Palmeri (1996)

Netherlands: Bink et al. (1980)

Poland: Szelegiewicz (1979), Klasa (1987)

Portugal: Bink-Moenen (1989)

Romania: Zahradnik (1991)

Spain: Bink-Moenen (1989), Llorens-Climent \& Garrido Vivas (1992)

Sweden: Gertsson (1987)

Switzerland: Zahradnik (1989a)

Syria: Iaccarino (1990)
Turkey: Uygun \& Elekçioğlu (1990), Ulusoy \& Uygun (1996), Ulusoy et al. (1996), Uygun et al. (1996)

former Yugoslavia: Zahradnik (1991)

Papers providing more general distributional data within the study area, for selected whitefly species, include faunistic studies by Bink-Moenen (1989, 1991, 1992). An economic account with a European bias, especially covering Spanish whitefly species and heavily illustrated with colour photographs of all life-cycle stages, was provided by Llorens-Climent \& Garrido Vivas (1992). Hernández-Suárez et al. (1997) provided an account of the problems posed by Aleurodicus dispersus and Lecanoideus floccissimus in the Canary Islands, similarly illustrated with many colour habitus photographs, which will greatly assist the recognition of these species in the event of any future introduction to new geographical areas. More general works on agricultural whitefly pests, especially of citrus crops, include those by Rapisarda (1990) and Passos de Carvalho (1994). 
In the accounts of individual whitefly species, country records that are based on published lists only, and are considered to be doubtful, are placed in square brackets and discussed.

\section{Check-list of whiteflies of Europe and the Mediterranean Basin}

* Species not recorded from the area of study but discussed in this account for quarantine reasons.

+ Species only recorded from glasshouses in the area of study, and not included in key.

\section{Aleyrodinae}

Acaudaleyrodes rachipora (Singh)

*Aleurocanthus spiniferus (Quaintance)

*Aleurocanthus woglumi Ashby

Aleurocanthus zizyphi Priesner \& Hosny

Aleurochiton acerinus Haupt

Aleurochiton aceris (Modeer)

Aleurochiton pseudoplatani Visnya

Aleuroclava similis (Takahashi) comb. n.

Aleurodes capreae Signoret nom. dub.

Aleurodes fraxini Signoret nom. dub.

Aleurolobus marlatti (Quaintance)

Aleurolobus olivinus (Silvestri)

Aleurolobus teucrii Mifsud \& Palmeri

Aleurolobus wunni (Ryberg)

${ }^{+}$Aleuropteridis filicicola (Newstead)

Aleurothrixus floccosus (Maskell)

Aleurotrachelus globulariae Goux

Aleurotrachelus rhamnicola (Goux)

Aleurotuba jelinekii (Frauenfeld)

${ }^{+}$Aleurotulus nephrolepidis (Quaintance)

Aleuroviggianus adanaensis Bink-Moenen

Aleuroviggianus adrianae Iaccarino

Aleuroviggianus graecus Bink-Moenen

Aleuroviggianus halperini Bink-Moenen

Aleuroviggianus polymorphus Bink-Moenen

Aleuroviggianus zonalus Bink-Moenen

Aleyrodes asari (Schrank)

Aleyrodes campanulae Salaas nom. dub.

Aleyrodes elevatus Silvestri

Aleyrodes lonicerae Walker

Aleyrodes proletella (Linnaeus)

Aleyrodes singularis Danzig

Asterobemisia carpini (Koch)

Asterobemisia obenbergeri (Zahradnik)

Asterobemisia paveli (Zahradnik)

Bemisia afer (Priesner \& Hosny)

Bemisia tabaci (Gennadius)

Bulgarialeurodes cotesii (Maskell)

Calluneyrodes callunae (Ossiannilsson)

Dialeurodes chittendeni Laing

Dialeurodes citri (Ashmead)

Dialeurodes kirkaldyi (Kotinsky)

Dialeurodes setiger (Goux)

Dialeurolobus rhamni Bink-Moenen

${ }^{\dagger}$ Filicaleyrodes williamsi (Trehan)

Neopealius rubi Takahashi

Parabemisia myricae (Kuwana)

Pealius azaleae (Baker \& Moles)

Pealius quercus (Signoret)

Simplaleurodes hemisphaerica Goux
Siphoninus immaculatus (Heeger)

Siphoninus phillyreae (Haliday)

Tetraleurodes bicolor Bink-Moenen

Tetraleurodes hederae Goux

Tetraleurodes neemani Bink-Moenen

Tetralicia ericae Harrison

Tetralicia iberiaca Bink-Moenen

Trialeurodes ericae Bink-Moenen

Trialeurodes lauri (Signoret)

Trialeurodes packardi (Morrill)

Trialeurodes ricini (Misra)

Trialeurodes sardiniae Rapisarda

Trialeurodes vaporariorum (Westwood)

Aleurodicinae

${ }^{*}$ Aleurodicus dispersus Russell

${ }^{+}$Ceraleurodicus varus (Bondar)

*Lecanoideus floccissimus Martin et al.

Paraleyrodes minei Iaccarino

\section{Key to puparia of whitefly species occurring in Europe and countries surrounding the Mediterranean Basin}

Notes: This key uses terminology which is peculiar to whitefly puparial systematics, and all the major characters are illustrated and annotated in fig. 2. Host plant preferences are mentioned in this key where these are sufficiently specific to assist identification. Absence, in the key, of such host information implies a degree of polyphagy, or insufficiently known preferences, and more detail is given in the inividual species accounts.

1. With subdorsal compound pores, each of which may bear a central process (figs $82 \mathrm{~b}, 83$ ) or be ring-like (fig. 84). Lingula large, tongue-shaped, with four stout setae. Each leg with an apical claw Aleurodicinae ...... 58

- Without subdorsal compound pores. Lingula with two setae (e.g. figs 11e, 28b, 31b), or none visible. Legs without claws (e.g. figs 5a, 6, 11a, 18a)

Aleyrodinae ...... 2

2. Dorsal disc with elongate spines or siphon-like setae, which may be apically acute (fig. 4), rounded (fig. 19) or variously expanded (figs 58,59 )

- Dorsal disc without elongate spines or siphon-like setae, but stout normal setae may be present on dorsal disc (figs 28, 29, 30a, 32, 42, 50) or submarginally (figs 6, 25, $26,53)$

3. Puparial margin regularly toothed (figs 4, 19b); operculum fully occupying vasiform orifice and obscuring lingula; dorsum with many acute spines, or with just four pairs of blunt siphon-like setae; vasiform orifice often slightly elevated

- Puparial margin smooth or slightly irregular, not toothed; operculum only occupying basal part of vasiform orifice, lingula head exposed (figs 58d, 59b); dorsum with many siphon-like setae with expanded apices (figs 58a, 59a); vasiform orifice not elevated Siphoninus ...... 5

4. With acute spines, distributed in a regular, paired pattern (fig. 4). Cuticle coloration very variable 


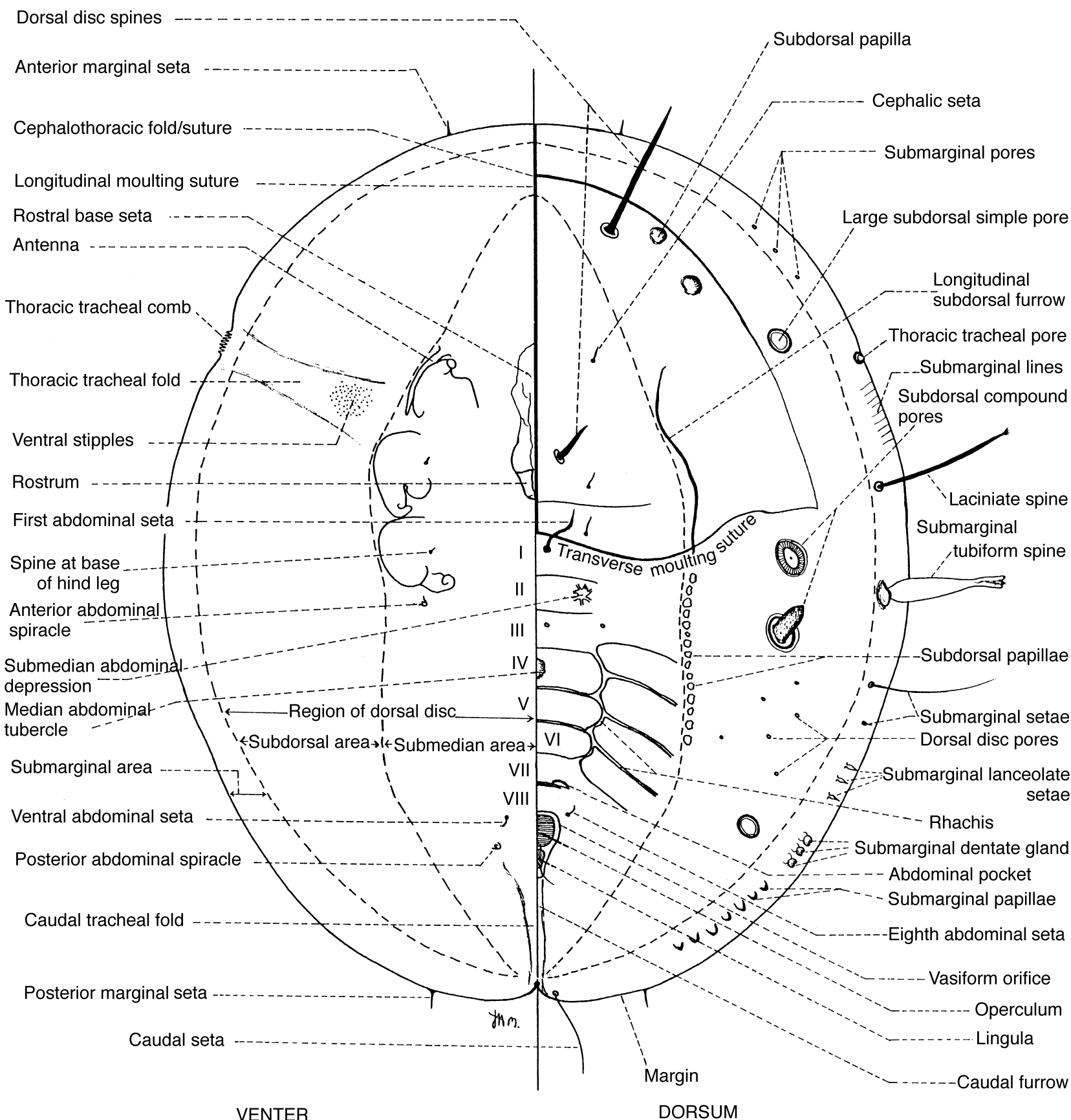

Fig. 2. Stylized whitefly puparium with major morphological features annotated (from Martin, 1987).

- With blunt siphon-like setae, restricted to single cephalic, meso- and metathoracic and eighth abdominal pairs (fig. 19). Cuticle evenly dark, often requiring bleaching, although marginal teeth paler. Usually on Viburnum tinus or Arbutus unedo ........ Aleurotuba jelinekii

5. Most siphons distinctly bifurcate apically (fig. 58b,c); sculpture of vasiform orifice floor usually with one especially large areola posteriorly (fig. 58d). On Hedera helix ............................................ Siphoninus immaculatus

- Most siphons blunt, expanded but rounded apically (fig. 59a); sculpture of vasiform orifice floor typically with more, smaller, areolae (fig. 59b). Favouring Oleaceae and Rosaceae, but not feeding on Hedera helix

Siphoninus phillyreae

6. Extreme outer submargin with a row, of normally 14 pairs, of fine but distinct setae which clearly extend beyond puparial margin; transverse moulting sutures reach puparial margin (fig. 53a); vasiform orifice (fig. 53b) triangular, posteriorly indistinct; lingula head exposed, basally bilobed, included in vasiform orifice 
and with a prominent pair of apical setae; caudal furrow absent; cuticle pale ............................. Parabemisia myricae - If outer submarginal setae present, then much coarser (figs 6, 25a, 26a), smaller and indistinct (fig. 45a), or significantly less in number (figs 8a, 20a, 27a); combination of other characters different ...................... 7

7. Operculum and lingula together occupying less than basal half of vasiform orifice whose floor is patterned with fine stippling; operculum much wider than long, lingula minute (fig. 3a,c); small groups of tubercle-like markings present along median line of abdominal segments; cuticle unicolorous, brown to black; margin regularly toothed (fig. $3 b$ ) but the teeth may be obscured by down-curling on slides .......... Acaudaleyrodes rachipora

- If operculum only occupying basal part of vasiform orifice then lingula always clearly visible and operculum and lingula together occupying more than half of orifice (e.g. figs 9c, 22d)

8. Lingula head distinctly lobulate, usually about as long as wide, at least partially exposed and always bearing a pair of apical setae; submargin, and sometimes also dorsal disc, with glandular papillae of various shapes (figs 65, 66, 69-80); margin either not modified at tracheal openings, or with subtle combs present (as in fig. 79) ........................................... Trialeurodes spp. ...... 9

- Lingula head usually of different form, sometimes with just a pair of basal lobes or without apical setae, or it is obscured by operculum; if lingula lobulate then submargin and dorsal disc without papillae (fig. 52) ...... 14

9. Puparia elongate-oval (figs 65,66 ); submarginal papillae present in several ranks and/or submedian thoracic setae are present. On Erica spp. ..................................... 10

- Puparia more broadly oval (figs 69-72, 74, 75, 77, 78); submarginal papillae usually present in a single row, with sometimes a few papillae in a second rank; submedian thoracic setae never present. On Erica spp. only rarely

10. Puparium black; with a broad submarginal zone of distinct papillae in several ranks (fig. 66)

Trialeurodes sardiniae

- Puparium pale brownish to almost black; submarginal papillae usually in one to two rows (fig. 65a); papillae usually distinct but sometimes faint

Trialeurodes ericae

11. Middle and hind legs each with a pair of stout spines (fig. 74); papillae acute, those in submarginal row contiguous (figs 69, 74) or very irregular (fig. 75) ........ 13

- Middle and hind legs with only tiny setae (fig. 81); papillae more truncate, often rather rounded apically (figs 70-72, 77-79)

12. Eighth abdominal setae placed anterior to widest part of operculum (figs 79, 80); margin crenulations coarser, usually less than 13 occupying $0.1 \mathrm{~mm}$; with a tiny tongue-like structure usually visible protruding beyond apical notch of vasiform orifice (fig. 80)

Trialeurodes vaporariorum

- Eighth abdominal setae placed posterior to widest part of operculum (fig. 73); marginal crenulations finer, usually more than 23 occupying $0.1 \mathrm{~mm}$; apical notch of vasiform orifice clear (fig. 73) ............ Trialeurodes packardi
13. Cephalic setae present and conspicuous (figs 74, 75); submarginal papillae often in an irregular row ................ Trialeurodes ricini

- Cephalic setae usually absent, or very inconspicuous if present; submarginal papillae in a regular single row, almost contiguous (fig. 69b). On Laurus nobilis and Arbutus andrachne Trialeurodes lauri

14. Lingula exposed but small, its head either littledifferentiated from stalk or short and rather ' $\mathrm{D}$ '-shaped; vasiform orifice rounded-trapezoidal, leading posteriorly into a wide and sculptured anterior caudal furrow (figs 5d, 7d, 8b, 9c, 54b, 55c) which sometimes continues to the puparial margin after narrowing. On Acer, azalea, deciduous Fagaceae or Betulaceae .......... 15

- Lingula often covered by operculum (e.g. figs 10d, 11d, $15 b, 18 c$ ) or with its head much larger (e.g. figs 31b, 32c, $33 \mathrm{c})$; if lingula head short and/or ' $\mathrm{D}$ '-shaped, then it is without apical setae (fig. 27d); if caudal furrow sculptured, then along whole length from vasiform orifice to puparial margin (figs 10d, 21a, 45c). On other hosts 19

15. Operculum almost fully occupying vasiform orifice (figs $5 d, 7 d, 8 b, 9 c)$, lingula usually slightly overlapping posterior margin of orifice; transverse moulting sutures reaching puparial margin. On Acer spp. Aleurochiton spp. ....... 16

- Operculum occupying about two-thirds of, and lingula included within, vasiform orifice (figs 54b, 55c); transverse moulting sutures terminating in subdorsum. On azalea, deciduous Fagaceae or Betulaceae

Pealius spp. ....... 18

16. Anterior part of caudal furrow poorly defined lateral to vasiform orifice (fig. 9c); submedian abdominal depressions on thorax and abdominal segments I-VII subcircular (fig. 9b). Usually on Acer pseudoplatanus ......... Aleurochiton pseudoplatani

- Anterior part of caudal furrow sharply defined lateral to vasiform orifice (figs $5 \mathrm{~d}, 7 \mathrm{~d}, 8 \mathrm{~b}$ ); submedian abdominal depressions on thorax and abdominal segments I-VII almost indistinguishable from other cuticular folding. Usually on Acer campestre or A. platanoides .................... 17

17. Spring/summer puparia with a submarginal row of normally 12 pairs of long, stout setae in outer submargin (fig. 6); overwintering puparia with submedian zone of venter delineated by an irregular fold, which is best defined cephalically and near the posterior abdominal spiracles (fig. 5a). Usually on Acer campestre

Aleurochiton acerinus

- Spring/summer puparia with submarginal setae minute (fig. 8a), often difficult to detect; overwintering puparia with submedian zone of venter not defined. Usually on Acer platanoides Aleurochiton aceris

18. Puparial outline broadly oval (fig. 55a). With the occasional exception of the posterior marginal pair, all dorsal setae are normally minute, much shorter than opercular length; thoracic tracheal openings at margin modified into rather long combs of teeth faintly marked on the ventral submargin (fig. 55b), but marginal crenulations themselves not modified. On deciduous Fagaceae or Betulaceae .............................. Pealius quercus

- Puparial outline elongate-oval (fig. 54a). Caudal, and sometimes also the cephalic, setae very long and stout, considerably longer than length of vasiform orifice (fig. 
54b); marginal crenulations at thoracic tracheal openings modified to form distinct, but short, combs of teeth. On cultivated azaleas

Pealius azaleae

19. Puparial outline circular (fig. 57a), extremely convex (on slides, puparium often splits when depressed by cover slip); margin with coarse teeth, each of which is longer than wide basally. Cuticle black. On Oleaceae...

Simplaleurodes hemisphaerica

- If outline circular, then puparia less convex, often almost flat dorsally

.. 20

20. Subdorsum defined by two rows of close-set pores, the inner row delineating a submedian area of characteristic shape, and the outer row marking the boundary with the submargin (fig. 43a); cuticle of subdorsum of fine porous, glandular, structure. On Rosa spp.

Bulgarialeurodes cotesii

- Subdorsum not thus defined as a glandular zone ........ 21

21. Vasiform orifice rounded-triangular, fully occupied by similarly-shaped operculum, which covers lingula, but with lingula remaining clearly visible through operculum (figs 11a, 11c, 12a, 13, 51d) ........................... 22

- If vasiform orifice fully occupied by operculum, it is shaped differently and opacity of operculum usually obscures lingula (e.g. figs 10d, 47, 48b, 50c) .................. 26

22. Wide submargin separated from dorsal disc by a suturelike fold (figs 11-15). Cuticle black

Aleurolobus spp. ...... 23

- Submargin not defined; transverse moulting sutures curving strongly anteriorly, almost meeting puparial margin opposite fore legs (fig. 51a). Cuticle black or, more rarely, pale Dialeurolobus rhamni

23. Outline subcircular (fig. 12a); thoracic tracheal openings at margin marked only by a few minute teeth which are much finer than remainder of marginal crenulations. On Oleaceae Aleurolobus olivinus

- Outline ovoid (figs 11, 13-15); thoracic tracheal openings at margin differently, or not, marked .. 24

24. Thoracic and caudal tracheal openings at margin each marked as a comb of three teeth modified from marginal crenulations, often appearing as a notch with a median tooth (fig. 11b); comma-shaped pale eyespots present (fig. 11a); vasiform orifice significantly longer than wide at its anterior end (fig. 11d) ................ Aleurolobus marlatti

- Thoracic and caudal tracheal openings at margin differently, or not, marked; eyespots absent; vasiform orifice sometimes not longer than wide at its anterior end (fig. 13)

25

25. Thoracic tracheal openings at margin completely unmarked; caudal tracheal opening indented, between caudal setae, marked as a comb of fine crenulations; vasiform orifice broadly cordate, smoothly rounded posteriorly (fig. 13). On Teucrium fruticans

Aleurolobus teucri

- Thoracic tracheal teeth slightly protuberant from marginal outline (fig. 15a), but the crenulations themselves differing little from those on remainder of margin; caudal tracheal opening not differentiated; vasiform orifice more elongate (fig. 15a,b) ......

Aleurolobus wunni

26. Vasiform orifice triangular or elongate-cordate, operculum only occupying anterior half of orifice and head of lingula clearly defined, mostly or fully exposed, elongate and similar in length to operculum (figs 28b, 30, 31b, 32c, 33-42, 44, 52b); lingula head always with a pair of apical setae; cuticle pale or brownish ........................ 27

- Vasiform orifice usually subcircular or cordate, with lingula completely or partially concealed by operculum (figs 10d, 16, 17c, 18c, 45c, 47, 48b, 50c, 60-64). If lingula fully exposed, its head is without a pair of apical setae (figs 20e, 22d, 23b, 24b, 25c, 26d, 27d)

27. Transverse moulting sutures curving abruptly anteriorly and becoming margin-concentric before meeting on the median line, forming a cordate emergence trapdoor which is bisected by the longitudinal moulting suture (figs 33-37) ................................. Asterobemisia spp. ....... 28

- Transverse moulting sutures normal, terminating posterior to meso- metathoracic suture (figs 28-32, $38-42,44,52)$

... 30

28. The pair of shallow ridges which border vasiform orifice meet posteriorly, forming a rounded ' $\mathrm{V}$ '-shaped figure; caudal furrow absent (figs 33, 34)

Asterobemisia carpini

- The pair of shallow ridges which border vasiform orifice do not meet posteriorly, but continue towards puparial margin, defining a caudal furrow (figs 35-37) ............... 29

29. Thoracic tracheal folds (ventral) densely punctuated by tiny subcircular tubercles (fig. 36b); marginal crenulations fine, about $14-16$ occupying $0.1 \mathrm{~mm}$ of lateral margin ........................... Asterobemisia obenbergeri

- Thoracic tracheal folds (ventral) marked by a pair of boundary folds but not, or only slightly, punctuated (fig. $37 \mathrm{c})$; marginal crenulations often coarser, $\leqslant 12$ occupying $0.1 \mathrm{~mm}$ of lateral margin Asterobemisia paveli

30. Abdominal segment VII not significantly reduced in length medially, eight subequal segments clearly visible between transverse moulting sutures and vasiform orifice (figs 28-32) ........................... Aleyrodes spp. ...... 31

- Abdominal segment VII much reduced in length medially (figs 38-42, 52), abdomen sometimes superficially appearing seven-segmented between transverse moulting sutures and vasiform orifice (as arrowed in fig. 39a) ........................................................ 35

31. Vasiform orifice broadly cordate, situated on an elevation; lingular apex extends to or slightly beyond lip of vasiform orifice; inner submargin with a regular row of hairs (fig. 32) ................................. Aleyrodes singularis

- Vasiform orifice rounded-triangular, more acute, not elevated; submargin without a regular row of hairs (figs 28-31)

... 32

32. Puparia rather elongate-oval and typically developing in large colonies with much secreted mealy wax; usually with cephalic, meso- and metathoracic, first, fourth and eighth abdominal and caudal setal pairs long and stout; abdominal segments II-VI with shallow median tubercles; often with slight median abdominal pigmentation (fig. 28). On Asarum europaeum .....

Aleyrodes asari

- Puparia more broadly oval (figs 30,31) and colonies with secreted wax less obvious; if puparia elongate-oval then with outline distorted by development amongst leaf hairs (fig. 29), and often with longitudinal subdorsal 
bands of cuticular pigmentation; dorsal disc setae usually only enlarged when feeding on hairy-leaved hosts (fig. 30a); shallow median abdominal tubercles present or absent. Not on Asarum europaeum ................. 33

33. Caudal setae always very small, usually hardly extending beyond puparial margin; cephalic, first and eighth abdominal setae similar (fig. 31); abdominal segments without median tubercles; vasiform orifice usually rounded-truncate posteriorly

Aleyrodes proletella

- At least some individuals with caudal setae extending beyond puparial margin (figs 29,30 ), even when feeding on smooth-leaved hosts; often these, and 0-6 pairs of dorsal disc setae, may be longer than vasiform orifice (figs 29, 30a); abdomen usually with shallow, smooth median tubercles segments II-V or II-VI; vasiform orifice often with a triangular apical lobe evident ...... 34

34. Puparium rather elongate (fig. 29), with dorsum strongly elevated above leaf surface, supported by up-curved venter which is protected by a waxy palisade; cuticle often partially pigmented, with a pair of longitudinal stripes visible with a hand lens. Usually on Ficus carica ..

Aleyrodes elevatus

- Puparium ovoid and not strongly elevated (fig. 30) ........ Aleyrodes lonicerae

35. Transverse moulting sutures reaching submargin, sometimes almost to puparial margin (figs 44a, 52a); thoracic tracheal folds each marked as a narrow band of tiny rounded tubercles (fig. 44b), or are unmarked (fig. 52a) 36

- Transverse moulting sutures shorter, terminating in subdorsum (figs 38-42); if thoracic tracheal folds punctuated, then by fine stippling only

Bemisia spp. ...... 37

36. Transverse moulting sutures almost reach puparial margin (fig. 44a); thoracic tracheal folds each marked as a narrow band of tiny rounded tubercles (fig. 44b); vasiform orifice triangular; lingula head acute. On Calluna spp. ................................... Calluneyrodes callunae

- Transverse moulting sutures terminate in inner submargin (fig. 52a); thoracic tracheal folds unmarked; vasiform orifice elongate-cordate; lingula head apically obtuse and sometimes somewhat lobulate (fig. 52b). Not on Calluna Neopealius rubi

37. Caudal setae always stout, usually at least as long as vasiform orifice whose sides are almost straight (figs 40-42); vasiform orifice always inset from puparial margin by less than its own length; with a single geminate pore/porette pair between median line and first abdominal seta ...................................... Bemisia tabaci

- Caudal setae usually less than half length of vasiform orifice whose sides are usually distinctly concave (figs 38, 39); vasiform orifice usually inset from puparial margin by at least its own length; most puparia with two geminate pore/porette pairs between median line and first abdominal seta

Bemisia afer

38. Puparial margin broadly (and usually rather unevenly) deflexed, with morphological true margin located in the 'subdorsal' zone of venter (figs 63a, 64a); vasiform orifice trapezoidal, completely occupied by operculum (figs 63b, 64b). Puparia black. On Erica spp...

Tetralicia spp. ....... 39
- If puparial margin slightly and evenly deflexed, then lingula fully or partly exposed (but note that downcurling may often occur in slide-preparations of some species)

39. Puparium elongate-oval; caudal setae usually protruding beyond margin (fig. 63a).......... Tetralicia ericae

- Puparium broadly oval; caudal setae short and obscured by the marginal deflexion (fig. 64a) ........ Tetralicia iberiaca

40. Puparial margin distinctly deflexed; vasiform orifice not completely occupied by operculum; lingula fully or partly exposed, its head without apical setae (figs 21, 23, 24-26). On evergreen Quercus spp.

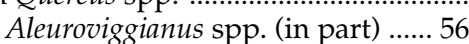

- Puparial margin not deflexed (but note comment on down-curling in couplet 38)

41. Wide submargin separated from dorsal disc by a distinct dorsal suture-like margin-concentric fold (figs 13, 16, 60-62)

- Submargin and subdorsum not thus defined on dorsum

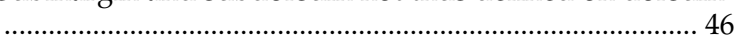

42. Although approximately margin-concentric overall submarginal/subdorsal fold arranged in distinct sections (fig. 16); fold complete between vasiform orifice and puparial margin; inner submargin with a row of five pairs of tiny setae in cephalothorax and anterior abdomen ........................................ Aleurothrixus floccosus

- Submarginal/subdorsal fold not in distinct sections, usually smoothly margin-concentric (figs 13, 60-62); fold absent posterior to vasiform orifice; if with submarginal setae these are distributed differently

43

43. Vasiform orifice cordate or rounded-triangular, not elevated; operculum covers lingula but much of lingular detail remains visible (fig. 13). Cuticle black Aleurolobus (in part) .......... 25

- Vasiform orifice subcircular to trapezoidal (figs 60-62), usually slightly elevated posteriorly; lingula hardly discernible beneath operculum. Cuticle pale or partly pigmented Tetraleurodes ...... 44

44. Meso- and metathoracic submedian setal pairs absent (fig. 60a); submedian part of dorsal disc pigmented brownish. On Myrtus communis ........ Tetraleurodes bicolor

- Meso- and metathoracic submedian setal pairs present (figs 61a, 62a); cuticle pale or dusky, unicolorous ......... 45

45. A row of evenly-spaced geminate pore/porettes placed in inner submargin, closer to the submarginal/subdorsal furrow than to the marginal tooth-base glands (fig. 61a). On Hedera helix Tetraleurodes hederae

- A row of unevenly-spaced geminate pore/porettes placed in outer submargin, just inside the row of marginal tooth-base glands (fig. 62a). Oligophagous, but not on Hedera Tetraleurodes neemani

46. Puparial margin modified at thoracic tracheal openings, in form of distinct pores or shallow, toothed, notches (figs 10, 46, 48, 49, 50b)

If puparial margin modified openings, then only as a slight indentation of the marginal outline

47. Puparial outline distinctive, laterally indented abdominally (fig. 10); puparial margin with very fine, even, crenulations 
- Puparial outline not laterally indented abdominally (figs $46,48-50)$; puparial margin smooth, or more coarsely crenulate

Dialeurodes spp. ...... 48

48. Thoracic and caudal tracheal openings at margin modified as shallow notches, each occupied by two or three (thoracic) or up to five (caudal) blunt teeth (fig. 50); often with cephalic, mesothoracic and first abdominal setae very long and hair-like (fig. 50a, left), but sometimes these are minute (fig. 50a, right). On Viburnum tinus and Arbutus unedo.

Dialeurodes setiger

- Thoracic and caudal tracheal openings at margin in form of distinct invaginated pores which are smooth or finely crenate internally (figs 46, 48, 49)

.. 49

49. Median line of puparium often pigmented brownish (examine several); first abdominal setae present but very small (fig. 48a); eighth abdominal setae opposite, or posterior to, widest part of operculum (fig. 48b)................

Dialeurodes kirkaldyi

- Puparium always pale; first abdominal setae absent (fig 46); eighth abdominal setae anterior to widest part of operculum (fig. 47) Dialeurodes citri

50. Transverse moulting sutures not reaching beyond subdorsum; eight abdominal segments clearly visible medially, between transverse moulting sutures and vasiform orifice; vasiform orifice approximately subcircular; operculum fully or mostly covering lingula head (figs 17, 18, 45); puparia of some species with a pair of longitudinal subdorsal folds (figs 17a, 18a) .............. 51

- Transverse moulting sutures reaching, or almost reaching, puparial margin; abdominal segment VII much reduced medially, abdomen superficially appearing seven-segmented between transverse moulting sutures and vasiform orifice; vasiform orifice cordate or rounded-triangular; lingula head usually fully, sometimes only partially, exposed and always without a pair of apical setae (figs 20-27); dorsal characters variable but without a pair of longitudinal subdorsal folds. On evergreen Quercus spp. Aleuroviggianus spp. ...... 53

51. Without a pair of longitudinal subdorsal folds (fig. 45); margin with rather irregular and very fine crenulations; cuticle entirely pale. On Rhododendron spp.

Dialeurodes chittendeni

- With a pair of longitudinal cephalothoracic subdorsal folds, overlying outer edges of legs (figs 17, 18); margin with pronounced, regular teeth; cuticle may be very dark, dusky or completely pale. Not on Rhododendron Aleurotrachelus ...... 52

52. Vasiform orifice ovoid, inset from puparial margin by less than twice its own length (fig. 17); marginal crenulations coarse, ten or less occupying $0.1 \mathrm{~mm}$. On Globularia alypum ..................... Aleurotrachelus globulariae

- Vasiform orifice cordate, usually inset from puparial margin by at least twice its own length (fig. 18); marginal crenulations fine, 12 or more occupying $0.1 \mathrm{~mm}$. On several hosts but not Globularia

Aleurotrachelus rhamnicola

53. Abdominal suture VI/VII visible medially, anterior to the abdominal pockets (figs 20, 22, 27; abdominal segment VII indicated in figs 20a, 22a); puparial margin not deflexed .................................................................... 54

- Abdominal suture VI/VII not visible anterior to the abdominal pockets, the pockets themselves thus marking the segment VI/VII boundary submedially (figs 21, 23, 24-26); puparial margin narrowly deflexed ..

54. Cuticle pale; apex of lingula usually extends beyond vasiform orifice (fig. 20e); abdomen with three or four distinct outer submarginal setae on each side but not apparently precisely paired)

Aleuroviggianus adanaensis

- Cuticle brown or black; if apex of lingula reaches posterior extremity of vasiform orifice, then it hardly overlaps it (fig. 22d); if abdomen with outer submarginal setae, then they are usually more difficult to discern .........

\section{5}

55. Lingula entirely included within vasiform orifice, its head short and ' $\mathrm{D}$ '-shaped (fig. 27d); abdomen with three or four outer submarginal setae on each side, often minute; first abdominal setae always absent

Aleuroviggianus zonalus

- Lingula just included within vasiform orifice, but reaching its posterior extremity (fig. 22d); without outer submarginal abdominal setae; first abdominal setae inconsistently present .................. Aleuroviggianus graecus

56. Cuticle pale or brownish; with host-dependent morphological variability (figs 24-26); if submargin with tubercle clusters, then each cluster bearing a stout seta (fig. 25a) ............................. Aleuroviggianus polymorphus

- Cuticle opaque-black; not morphologically variable, always with submarginal tubercle clusters (figs 21, 23); if tubercle clusters bear setae then only on abdomen and the setae are minute 57

57. Caudal furrow very narrow, unpunctuated; puparial outline indented posteriorly; abdomen distinctly wider than cephalothorax (fig. 23)........ Aleuroviggianus halperini - Caudal furrow broader and punctuated by subcircular rounded-reticulate markings; puparial outline not indented posteriorly; abdomen not wider than cephalothorax (fig. 21) ................ Aleuroviggianus adrianae

58. Compound pores with anteriormost two abdominal pairs much smaller than cephalic and posteriormost four abdominal pairs (fig. 84a). Puparia generally smaller (usually $\leqslant 0.90 \mathrm{~mm}$ and often $\leqslant 0.75 \mathrm{~mm}$ )

Paraleyrodes minei

- Compound pores with cephalic pair similar in size to anteriormost two abdominal pairs; each pore usually with a central process visible (figs $82 b, 83$ ). Puparia relatively large (often $\geqslant 1.00 \mathrm{~mm}$ )

... 59

59. Outer submarginal zone with a distinct ring of doublerimmed pores; dorsal disc mesad of compound pores densely punctuated by septate pores (fig. 82b); on slides, central processes of compound pores usually directed laterally as in fig. 82a.......................... Aleurodicus dispersus (currently not reported from Europe or the Mediterranean)

- Submarginal zone without a ring of double-rimmed pores, only with a band of crowded wide-rimmed pores (fig. 83, inset detail); dorsal disc mesad of compound 
pores only sparsely punctuated by septate pores; on slides, central processes of compound pores usually directed mesally as in fig. 83) ...... Lecanoideus floccissimus (currently not reported from Europe or the Mediterranean)

\section{Species native or naturalized in the study region Subfamily ALEYRODINAE \\ Genus Acaudaleyrodes Takahashi}

Acaudaleyrodes Takahashi, 1951: 382. Type species A. pauliani Takahashi, 1951: 382-384.

\section{Acaudaleyrodes rachipora (Singh)} (fig. 3)

Aleurotrachelus rachipora Singh, 1931: 57-59

Acaudaleyrodes rachipora (Singh) Russell, 1962: 64

Acaudaleyrodes citri (Priesner \& Hosny, 1934a: 7-8) [synonymized by Jesudasan \& David, 1991: 242].

Distribution. Europe and Mediterranean countries: Crete, Cyprus, Egypt, Israel, Jordan, Portugal, Rhodes, Spain, Syria, Turkey. Elsewhere in Palaearctic Region: Canary Islands, Iran, Iraq, Saudi Arabia. Ethiopian Region: widely distributed. Oriental Region: India, Pakistan.

Host plants. Moderately polyphagous on woody dicotyledonous hosts, with 13 families listed by Mound \& Halsey (1978) and others recorded subsequently. Occasionally a minor pest of citrus crops, pomegranate and guava.

Comments. This species is widespread and common in Africa, the Indian subcontinent and the Middle East, extending into the Mediterranean Basin. It has recently been found in the Canary Islands and on the Iberian Peninsula.

\section{Genus Aleurocanthus Quaintance \& Baker}

Aleurocanthus Quaintance \& Baker, 1914: 102. Type species Aleurodes spinifera Quaintance, 1903: 63-64.

\section{Aleurocanthus zizyphi Priesner \& Hosny (fig. 4)}

Aleurocanthus zizyphi Priesner \& Hosny, 1934b: 2-4

Distribution. Europe and Mediterranean countries: Egypt, Israel, Jordan Ethiopian Region: Chad, Sudan, Uganda.

Host plants. Balanitaceae: Balanites aegyptiaca; Combretaceae: Terminalia laxiflora; Euphorbiaceae: Phyllanthus mullerianus; Leguminosae: Dalbergi sp., Detarium microcarpum; Lythraceae: Lawsonia inermis; Myrtaceae: Psidium guajava; Moraceae: Ficus ?capensis; Ochnaceae: Ochna afzelii Rhamnaceae: Ziziphus spinachristi; Sapindaceae: Paullinia pinnata.

Comments. Amongst over 65 described species, A. zizyphi is the only member of the genus found in the Europe-Mediterranean area, and has no status as a pest. This is an Ethiopian Region species which extends from the Nile valley into the Middle East, where records known to the author concern only colonies feeding on Ziziphus spinachristi. The puparial cuticle is usually rather unevenly dusky to brownish, but may be pale.

Two species of Aleurocanthus not recorded from Europe, but listed as quarantine threats (Smith et al., 1997) are A. woglumi Ashby and $A$. spiniferus (Quaintance). The former has been recorded from Oman (BMNH) and the latter from the northern Ethiopian Region (Mound \& Halsey, 1978). In contrast to A. zizyphi, both of these species have puparial cuticle which is completely black and opaque. Aleurocanthus spiniferus and A. woglumi are discussed and figured by Martin $(1987,1999)$, along with other economically important members of the genus.

\section{Genus Aleurochiton Tullgren}

Aleurochiton Tullgren, 1907: 14-15. Type species Chermes aceris ovatus Geoffroy, 1762, a rejected trinomial and a synonym of Coccus aceris Modeer, 1778: 21.

Aleurochiton (Nealeurochiton) Sampson, 1943: 201. Type species Aleurodes forbesii Ashmead 1893: 294 [synonymized by Mound \& Halsey, 1978: 27]. Nealeurochiton Sampson; Zahradnik, 1963: 8, 12.
Comments. In common with other whiteflies whose members feed only on deciduous hosts in temperate climes, all the species of Aleurochiton overwinter as robust puparia which fall to the ground on the senescing leaves. Adults then emerge in the spring and fly back onto their host to lay the eggs of the spring generation. Aleurochiton is unusual in displaying marked puparial dimorphism, especially in A. acerinus and $A$. aceris, with summer and overwintering puparia differing greatly. Their summer puparia have pale cuticle, whereas the overwintering ones are more sclerotic: also, overwintering puparia often secrete a thick coating of wax, which is absent in summer forms.

\section{Aleurochiton acerinus Haupt \\ (figs 5, 6)}

Aleurochiton acerina Haupt, 1934: 1137-1139.

Aleurochiton acerinus Haupt; emended by Mound \& Halsey, 1978: 28.

Distribution. Europe and Mediterranean countries: Austria, Bulgaria, Czechoslovakia, England, France, Germany, Hungary, Italy, Poland, Romania, Sardinia, Sicily, Yugoslavia. Elsewhere in Palaearctic Region: Federation of Independent States.

Host plants. Aceraceae: Acer campestre.

Comments. This species is apparently more common in southern parts of Europe than in the north, in contrast to A. aceris which is a more northerly species, but both species are found in many European countries. The record for the British Isles is based upon a single known occurrence in southern England, involving successfully overwintering puparia and emergent adults (Dolling \& Martin, 1985).

\section{Aleurochiton aceris (Modeer) (figs 7,8 )}

Coccus aceris Modeer 1778: 21.

Lecanium complanatum Baerensprung, 1849: 169-170 [synonymized by Danzig, 1966: 367]

Aleurochiton complanatus (Baerensprung) Schumacher, 1918: 404 Aleurochiton aceris (Modeer) Danzig, 1966: 367 [198]

Distribution. Europe and Mediterranean countries: Austria, Bulgaria, Czechoslovakia, Denmark, England, Finland, France, Germany, Hungary, Italy, Lithuania, Netherlands, Norway, Poland, Romania, Sweden, Switzerland, Yugoslavia. Elsewhere in Palaearctic Region: Federation of Independent States.

Host plants. Aceraceae: Acer platanoides, A. tataricum.

Comments. This species is widely distributed across Europe, but is usually found in areas with a continental climate, where its usual host, $A$. platanoides, normally grows. Aleurochiton aceris is now common in southern England, where its presence was unproven until 1976 (Mound, 1966; Martin, 1978).

\section{Aleurochiton pseudoplatani Visnya}

(fig. 9)

Aleurochiton pseudoplatani Visnya, 1936: 116-117.

Nealeurochiton pseudoplatani (Visnya) Zahradnik, 1963: 12.

Aleurochiton pseudoplatani Visnya; Danzig, 1966: 366 [198]

Distribution. Europe and Mediterranean countries: Austria, Czechoslovakia, France, Germany, Hungary, Italy, Netherlands, Poland, Romania, Sicily, Switzerland. Elsewhere in Palaearctic Region: Federation of Independent States.

Host plants. Aceraceae: Acer monspessulanum, A. opalus, A. pseudoplatanus. Comments. This species bears closer resemblance to the sole North American species, A. forbesii (Ashmead), than to the other two European species. For this reason, Zahradnik (1963) included pseudoplatani in Nealeurochiton Sampson, which had been proposed by Sampson (1943) to accommodate forbesii. However, Mound \& Halsey (1978) considered that Nealeurochiton should be regarded as a junior synonym of Aleurochiton.

Although usually developing on Acer pseudoplatanus, this species has also been noted in Europe on A. monspessulanum and A. opalus (R.M. BinkMoenen, personal communication).

\section{Genus Aleuroclava Singh}

Aleuroclava Singh, 1931: 90-91. Type species Aleuroclava complex Singh, 1931: 91-92.

Aleurotuberculatus Takahashi, 1932: 20. Type species Aleurotuberculatus gordoniae Takahashi, 1932: 21-22 [synonymized by Martin, 1999: 31]. 

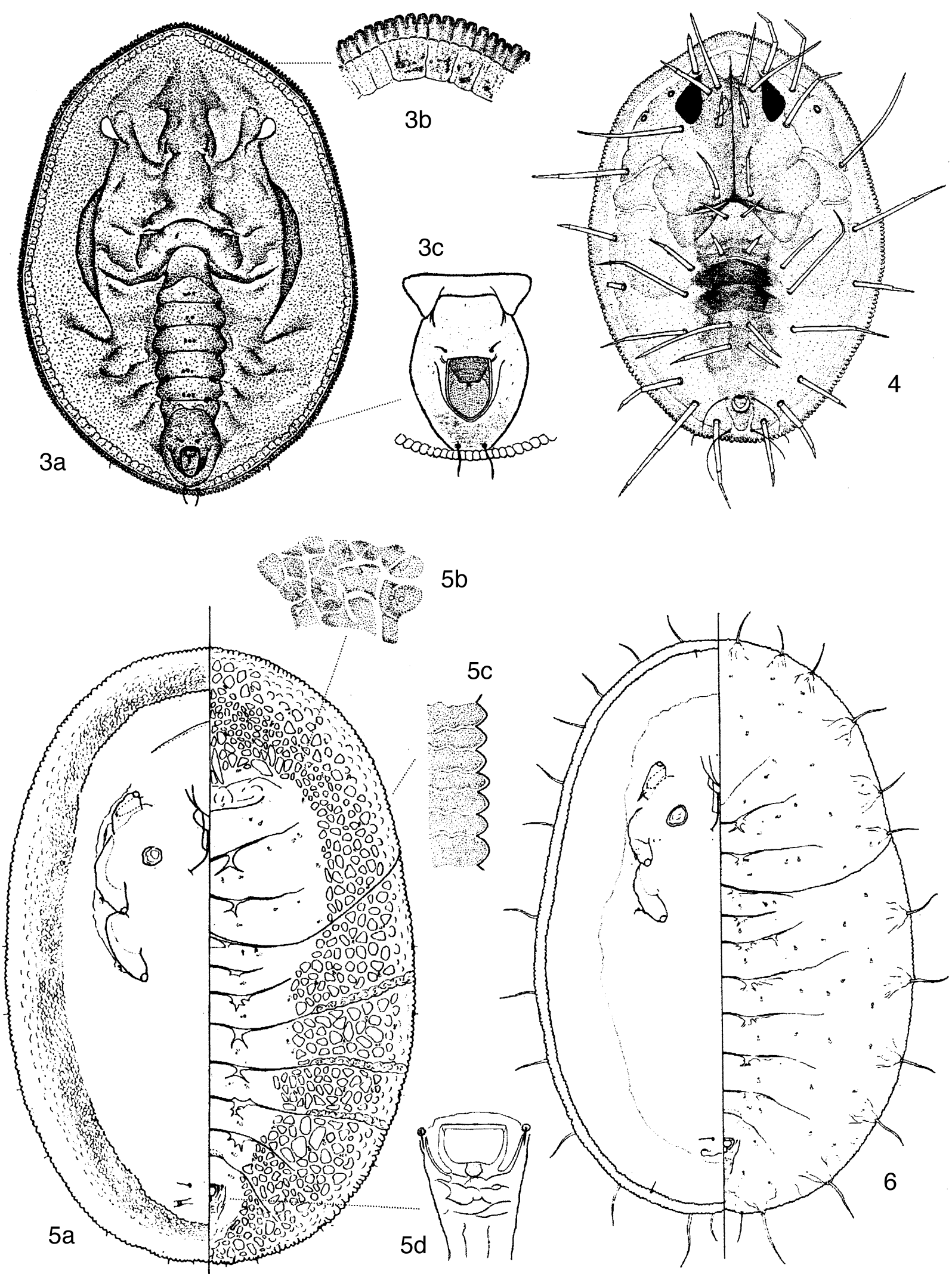

Figs 3-6. 3, Acaudaleyrodes rachipora, puparium (from Priesner \& Hosny, 1934a); 4, Aleurocanthus zizyphi, puparium (from Priesner \& Hosny, 1934b); 5, Aleurochiton acerinus, overwintering puparium (adapted from Rapisarda, 1982); 6, Aleurochiton acerinus, summer puparium (from Rapisarda, 1982). 
Japaneyrodes Zahradnik, 1962: 13-14. Type species Aleurotuberculatus trachelospermi Takahashi, 1938: 72-73 [synonymized by Mound \& Halsey, 1978: 78]

\section{Aleuroclava similis (Takahashi) comb. $\mathbf{n}$. (fig. 10)}

Aleurotuberculatus similis Takahashi, 1938: 73-74. Japaneyrodes similis (Takahashi) Zahradnik, 1962: 14.

Japaneyrodes similis europeaus Zahradnik, 1962: 15-18 [synonymized by Danzig, 1980: 595].

Japaneyrodes similis suborientalis Danzig, 1966: 383-384 [208] [synonymized by Danzig, 1980: 595].

Distribution. Europe and Mediterranean countries: Austria, Czechoslovakia, Finland, Germany, Netherlands, Norway, Poland, Sweden. Elsewhere in Palaearctic Region: Federation of Independent States, Japan. Nearctic Region: USA (Connecticut, New York, Rhode Island).

Host plants. Aquifoliaceae: Ilex spp.; Ericaceae: Leucothoe sp., Pieris japonicum, Rhododendron sp., Vaccinium vitis-idaea; Theaceae: Eurya japonica.

Comments. In Europe, Siberia and in the Maritime Territory of Russia, A. similis appears to be monophagous on Vaccinium vitis-idaea, but in the far east of the former USSR and in Japan it is oligophagous (Danzig, 1980). Danzig continued her discussion of this species to consider that puparial variation indicated that the use of subspecies was inappropriate.

\section{Genus Aleurolobus Quaintance \& Baker}

Aleurolobus Quaintance \& Baker, 1914: 108-109. Type species Aleurodes marlatti Quaintance, 1903: 61-63.

\section{Aleurolobus marlatti (Quaintance)}

$$
\text { (fig. 11) }
$$

Aleurodes marlatti Quaintance, 1903: 61-63.

Aleurolobus marlatti (Quaintance) Quaintance \& Baker, 1914: 109. Aleurolobus niloticus Priesner \& Hosny, 1934b: 1-5 [synonymized by Martin, 1999: 43].

Distribution. Europe and Mediterranean countries: Egypt, Jordan, Malta Sicily. Elsewhere in Palaearctic Region: Iran, Saudi Arabia. Ethiopian Oriental and Austro-oriental Regions: widely distributed. Australia: Northern Territory, Queensland, Western Australia.

Host plants. A wide variety of hosts, mostly woody dicotyledonous plants. Hosts from 24 families were listed by Mound \& Halsey (1978), and this whitefly species has been found on many other hosts since.

Comments. The characters of the vasiform orifice vary slightly across the range of this species, but the examination of type material of $A$. marlat (Japan) and A. niloticus (Egypt) led to the conclusion that the two species are synonymous (Martin, 1999)

\section{Aleurolobus olivinus (Silvestri)}

$$
\text { (fig. 12) }
$$

Aleurodes olivinus Silvestri, 1911: 214-222.

Aleurolobus olivinus (Silvestri) Quaintance \& Baker, 1915: xi

Distribution. Europe and Mediterranean countries: Corsica, Crete, Cyprus, France, Greece, Israel, Italy, Jordan, Mallorca, Morocco, Portugal, Sardinia, Sicily, Spain, Syria, Turkey.

Host plants. Ericaceae: Erica arborea; Oleaceae: Olea europaea, Phillyrea angustifolia, P. latifolia.

Comments. This species is only known from the Mediterranean countries, where it occasionally becomes a minor pest of olives. Although clearly favouring oleaceous hosts, it has also been recorded from Erica (BinkMoenen, 1989).

\section{Aleurolobus teucrii Mifsud \& Palmeri}

$$
\text { (fig. 13) }
$$

Aleurolobus teucrii Mifsud \& Palmeri, 1996: 89-95.

Distribution. Europe and Mediterranean countries: Malta, Sicily.

Host plants. Labiatae: Teucrium fruticans.

Comments. This species is currently only known from colonies on Malta and Sicily, all on the same small, herbaceous host plant.

\section{Aleurolobus wunni (Ryberg)}

(figs 14, 15)

Aleurodes asari Wünn, 1926: 28

Aleurodes Wünni [sic] Ryberg, 1938: 20 [replacement name for Aleurodes asari Wünn nec Aleurodes asari Schrank, 1801].

Aleurolobus wunni (Ryberg) Mound \& Halsey, 1978: 39.

Distribution. Europe and Mediterranean countries: Austria, Bulgaria, Czechoslovakia, Finland, France, Germany, Hungary, Italy, Latvia, Lithuania, Poland, Romania, Sweden, Switzerland, Yugoslavia. Elsewhere in Palaearctic Region: Federation of Independent States.

Host plants. Aristolochiaceae: Asarum europaeum; Caprifoliaceae: Linnaea borealis, Lonicera fragrantissima, L. nigra, L. tatarica, Symphoricarpos albus, $S$ racemosus; Labiatae: Phlomis sp.; Ranunculaceae: Cimicifuga sp., Clematis vitalba; Rosaceae: Spiraea sp.

Comments. Aleurolobus wunni is a European species which appears to be at least moderately polyphagous.

\section{Genus Aleurothrixus Quaintance \& Baker}

Aleurothrixus Quaintance \& Baker 1914: 103-104. Type species Aleyrodes howardi Quaintance, 1907: 91-94, a junior synonym of Aleurodes floccosa Maskell, 1896: 432-433.

\section{Aleurothrixus floccosus (Maskell) (fig. 16)}

Aleurodes floccosa Maskell, 1896: 432-433.

Aleyrodes howardi Quaintance, 1907: 91-94 [synonymized by Costa Lima 1942: 425]

Aleurothrixus floccosus (Maskell), Quaintance \& Baker, 1914: 103.

Distribution. Europe and Mediterranean countries: Cyprus, France, Greece, Israel, Italy, Malta, Morocco, Portugal, Sardinia, Sicily, Spain, Tunisia, Turkey. Elsewhere in Palaearctic Region: Canary Islands, Japan (Okinawa), Madeira. Ethiopian Region: widely distributed. Oriental Region: India. Austro-oriental Region: Philippines, Singapore. Pacific Region: Galapagos Islands, Tahiti. Malagasian Region: Mauritius, Réunion. Neotropical Region: widely distributed. Nearctic Region: southern USA.

Host plants. Although only known as a pest of citrus crops in the Mediterranean area, A. floccosus is a polyphagous species, 18 families having been listed by Mound \& Halsey (1978) and with many more recorded since (BMNH, London). Aleurothrixus floccosus has occasionally been discovered feeding on monocotyledonous hosts.

Comments. There is a question over the identity of this species, with some populations having the puparial subdorsum darkly coloured, whils others have the puparia entirely pale; the significance of this difference remains to be investigated (see discussion by Martin, 1999)

\section{Genus Aleurotrachelus Quaintance \& Baker}

Aleurotrachelus Quaintance \& Baker, 1914: 103. Type species Aleurodes tracheifer Quaintance, 1900: 38-39.

\section{Aleurotrachelus globulariae Goux}

(fig. 17)

Aleurotrachelus globulariae Goux, 1942: 145-148.

Distribution. Europe and Mediterranean countries: France, Israel, Morocco.

Host plants. Globulariaceae: Globularia alypum

Comments. This species has been little collected, despite its only known host being widely distributed in the Mediterranean area. Detailed examination of many plants in the Alicante area of Spain failed to yield any whitefly specimens (R.M. Bink-Moenen, personal communication) but, nonetheless, its disjunct recorded distribution is unlikely to represent reality.

\section{Aleurotrachelus rhamnicola (Goux)} (fig. 18)

Aleyrodes rhamnicola Goux, 1940: 47-48

Aleurotrachelus espunae Gomez-Menor, 1945: 298-302 [synonymized by Martin et al., 1996: 123].

Aleurotrachelus rhamnicola (Goux) Martin et al . (1996: 123). 


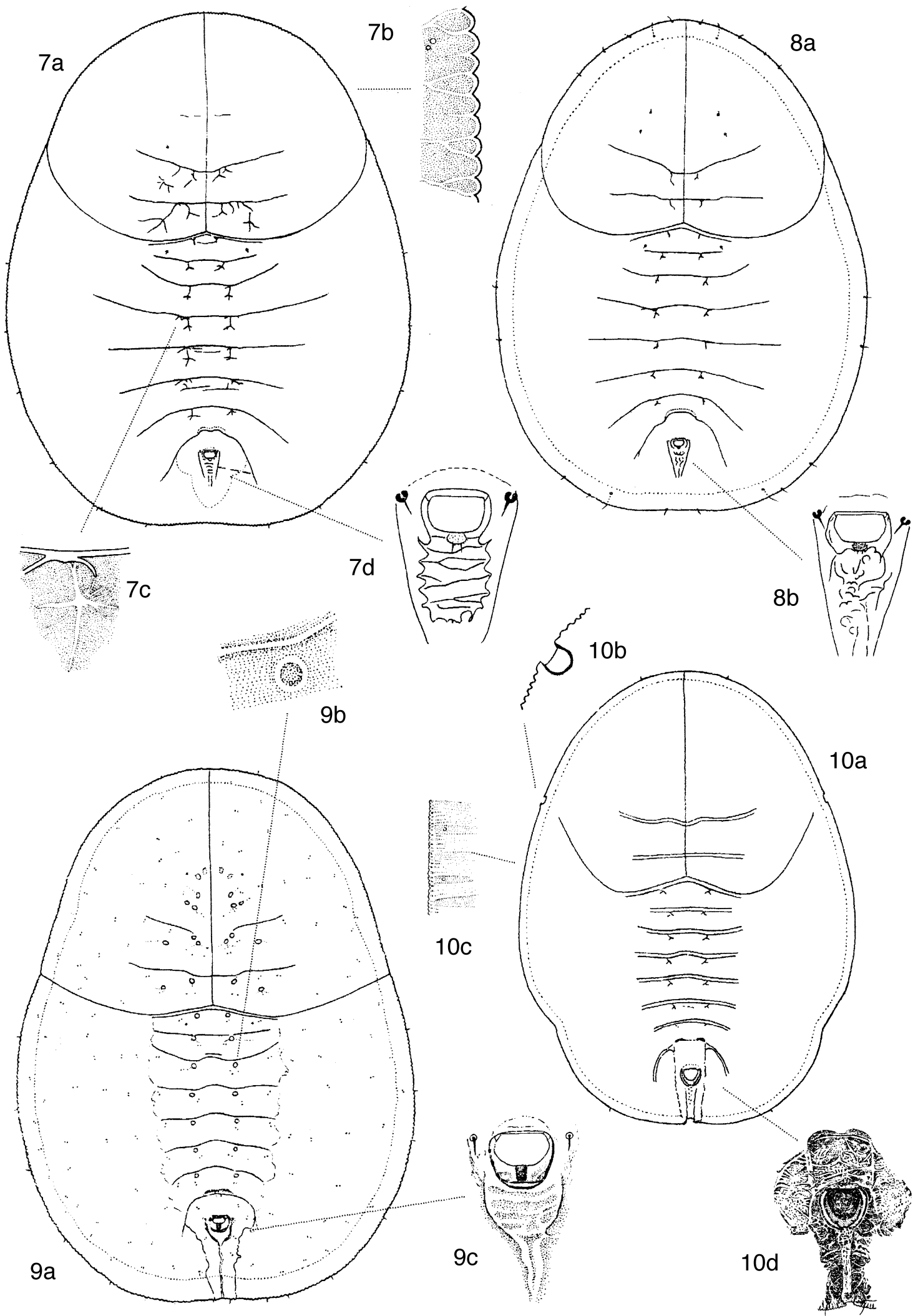

Figs 7-10. 7. Aleurochiton aceris, overwintering puparium (from Zahradnik, 1987b); 8, Aleurochiton aceris, summer puparium (from Zahradnik, 1987b); 9, Aleurochiton pseudoplatani, puparium (from Zahradnik, 1987b); 10, Aleuroclava similis, puparium (from Zahradnik, 1989b). 


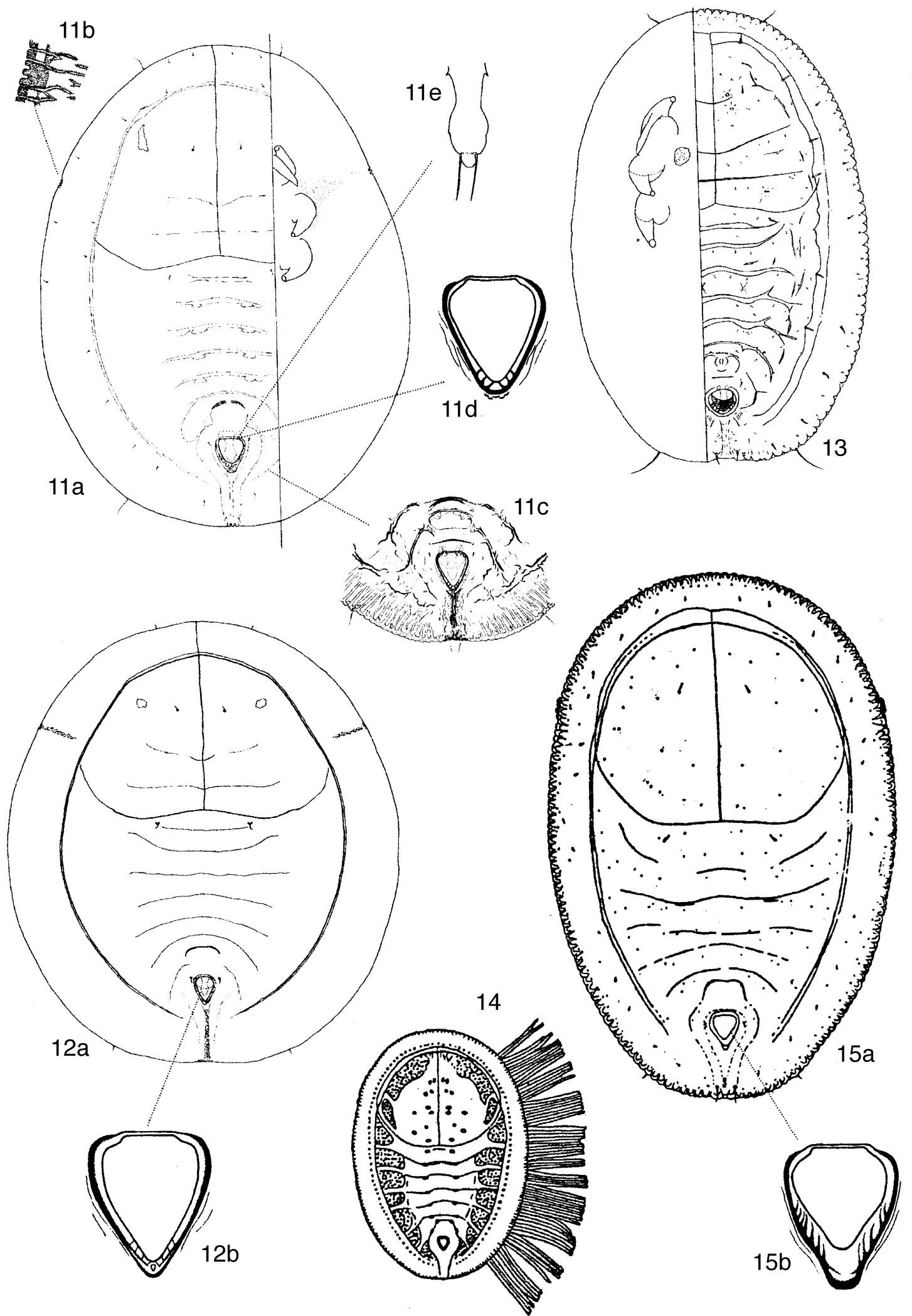

Figs 11-15. 11, Aleurolobus marlatti, puparium (adapted from Martin, 1999 and Rapisarda, 1985); 12, Aleurolobus olivinus, puparial dorsum (from Martin, 1987); 13, Aleurolobus teucrii, puparium (from Mifsud \& Palmeri, 1996); 14, Aleurolobus wunni, puparium with wax patterning (from Goux, 1942, as A. clematidis); 15, Aleurolobus wunni, puparium (adapted from Goux, 1942, as A. clematidis). 

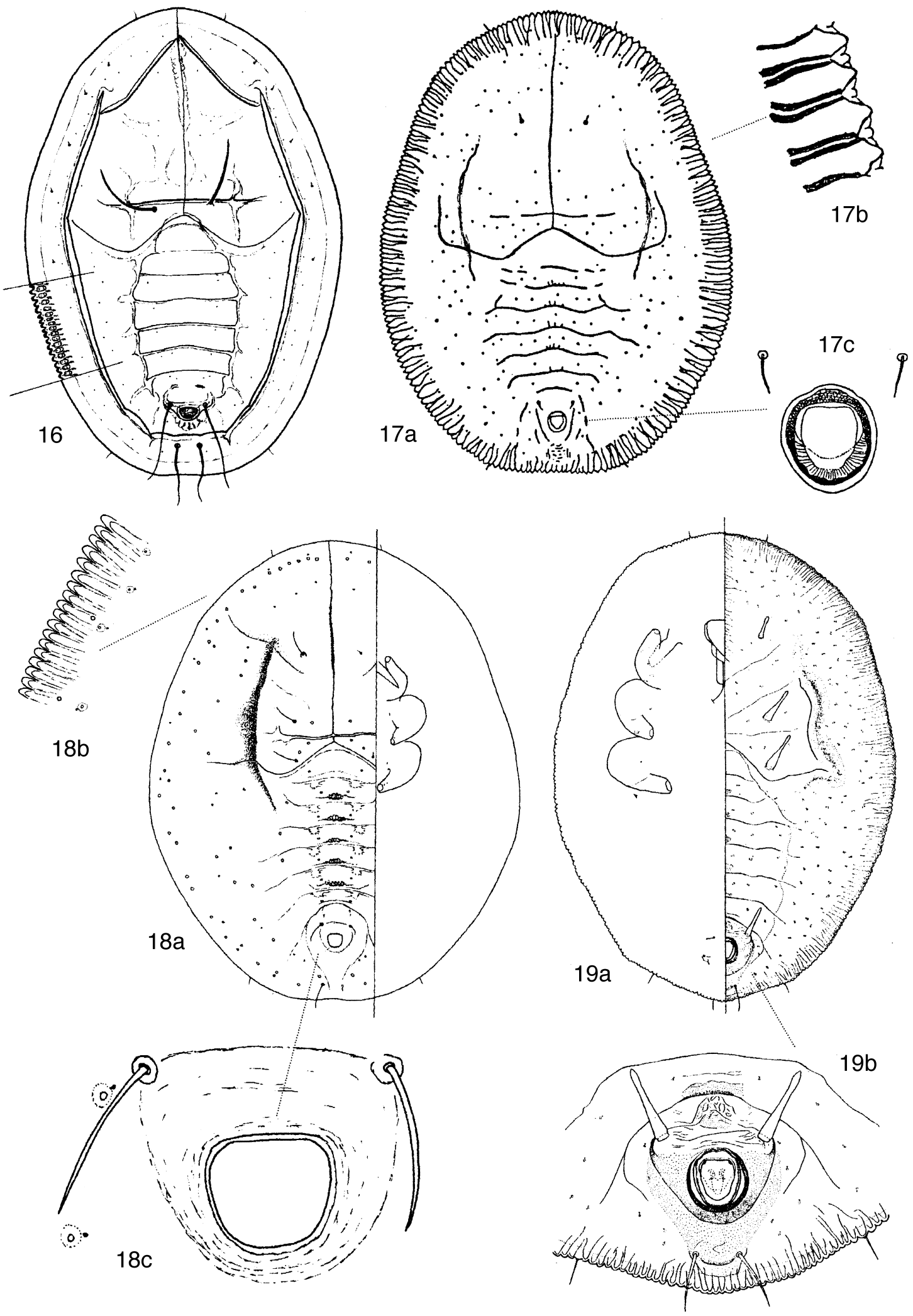

Figs 16-19. 16, Aleurothrixus floccosus, puparium with inset detail of margin and submargin (from Martin, 1987); 17, Aleurotrachelus globulariae, puparium (from Goux, 1942); 18, Aleurotrachelus rhamnicola, puparium (from Martin et al., 1996); 19, Aleurotuba jelinekii, puparium (from Rapisarda, 1982). 


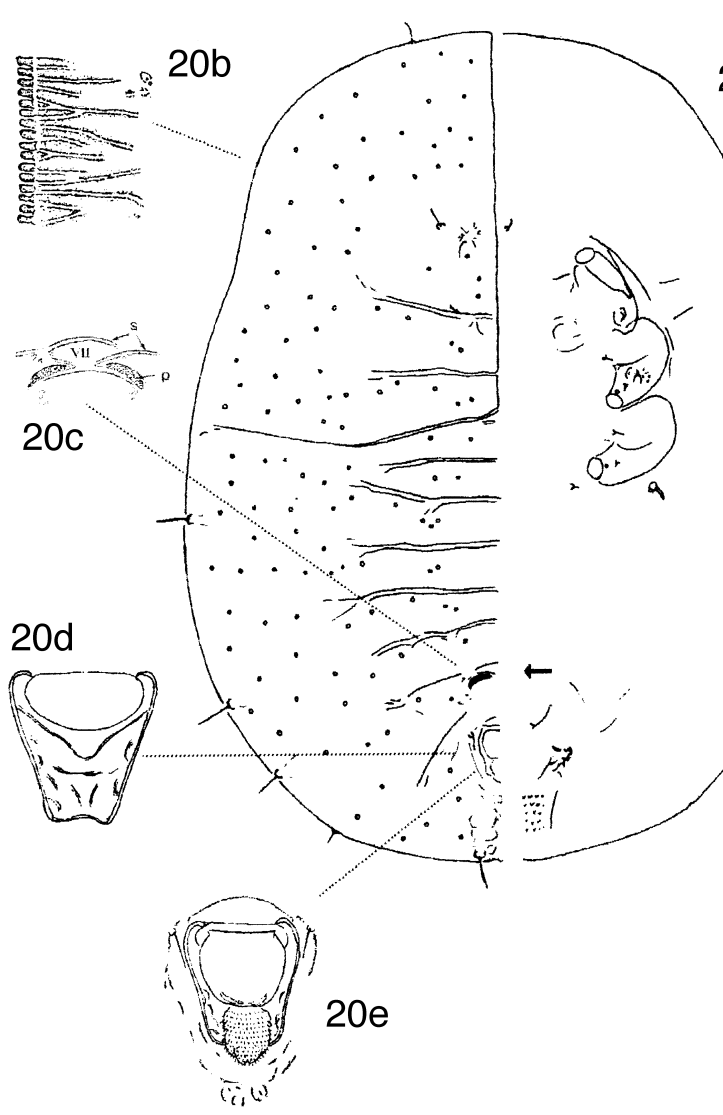

$20 a$

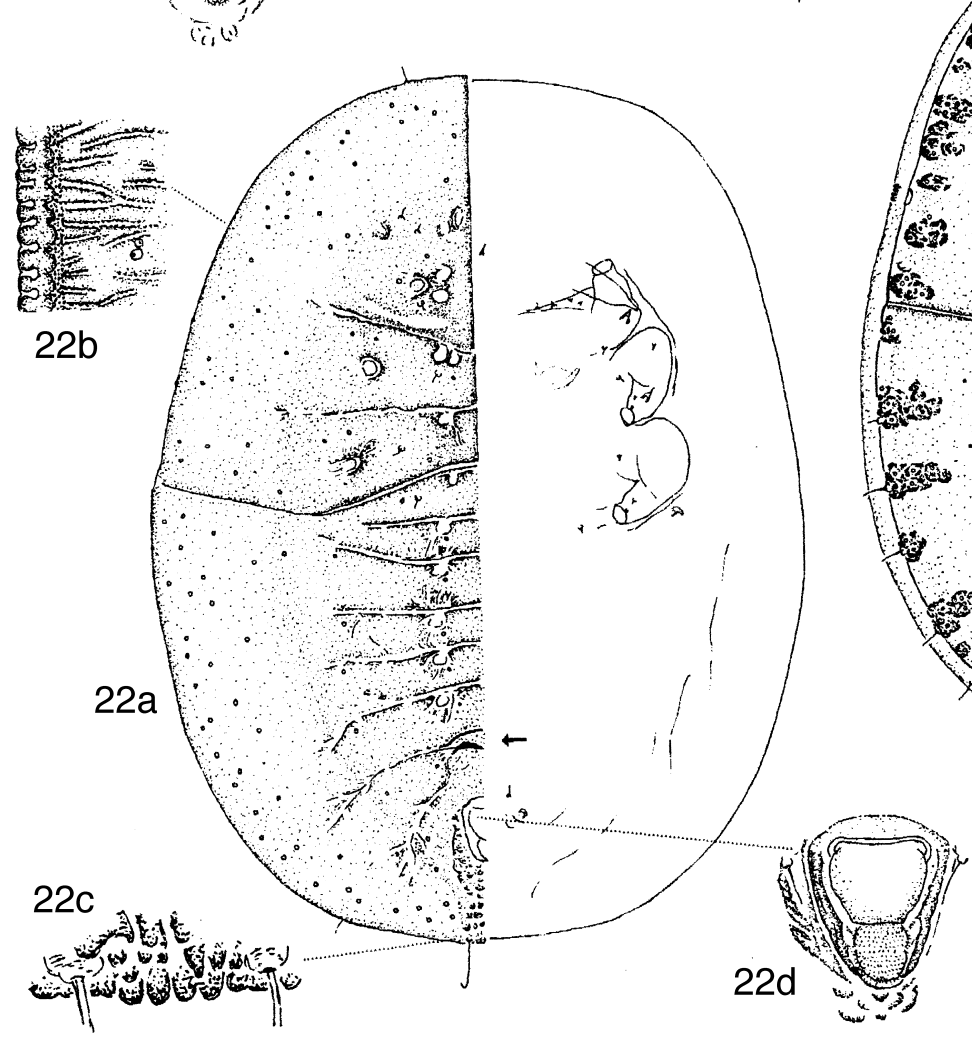

Figs 20-23, Aleuroviggianus spp., puparia (adapted from Bink-Moenen, 1992). 20, A. adanaensis, with median abdominal segment VII arrowed; 21, A. adrianae; 22, A. graecus, with median abdominal segment VII arrowed; 23, A. halperini. 


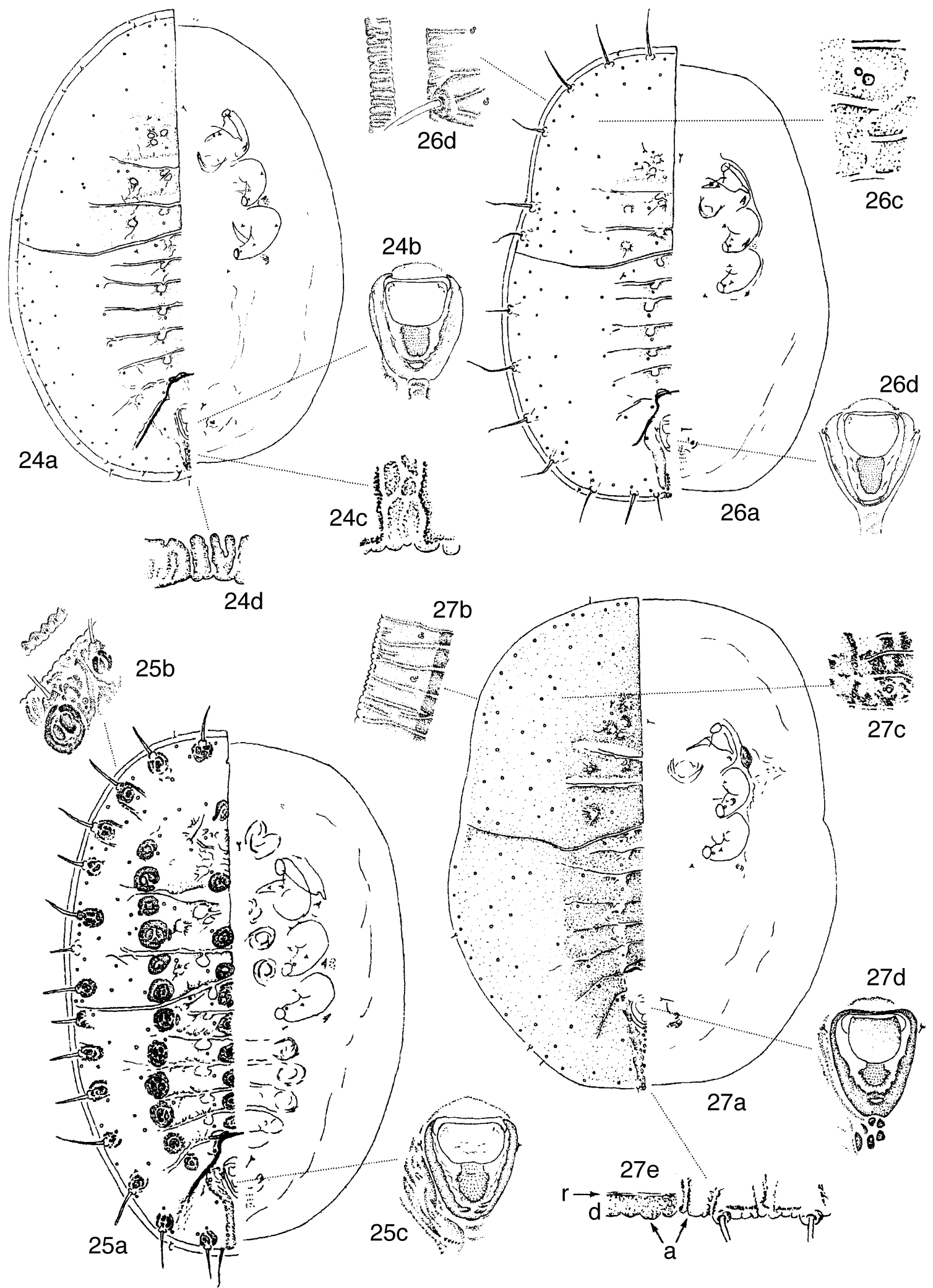

Figs 24-27, Aleuroviggianus spp., puparia (adapted from Bink-Moenen, 1992). 24-26, A. polymorphus, with abdominal segment VII/VIII boundary slightly exaggerated for clarity: 24, upper surface morph from Quercus rotundifolia; 25, lower surface morph from $Q$. rotundifolia; 26, holotype from Q. coccifera; 27, A. zonalus. 
Distribution. Europe and Mediterranean countries: Corsica, Crete, France, Greece, Italy, Mallorca, Malta, Morocco, Portugal, Sicily, Spain. Elsewhere in Palaearctic Region: Madeira.

Host plants. [Berberidaceae: Berberis sp.]; Ericaceae: Arbutus unedo [Fagaceae: Quercus sp.]; Passifloraceae: Passiflora edulis; Ranunculaceae: Clematis vitalba; Rhamnaceae: Rhamnus alaternus, Rhamnus sp.; Rosaceae: Rosa sp., Rubus fruticosus agg.; Vitaceae: Ampelopsis sp.

Comments. Aleurotrachelus rhamnicola appears to be polyphagous and widely distributed across the Mediterranean Basin. Its puparia are sometimes evenly dark and sometimes pale to dusky, and this variation was discussed in connection with the proposal to place A. espunae as a junior synonym of rhamnicola (Martin et al., 1996). The records of Berberis and Ouercus as hosts, quoted above, are questionable: Gomez-Menor recorded Berberis as the sole host when describing A. espunae (1945), but subsequently (1953) stated that espunae was 'only encountered on Quercus'.

\section{Genus Aleurotuba Tremblay \& Iaccarino}

Aleurotuba Tremblay \& Iaccarino, 1978: 60-61. Type species Aleurodes jelinekii Frauenfeld, 1867: 799-800.

\section{Aleurotuba jelinekii (Frauenfeld) (fig. 19)}

Aleurodes jelinekii Frauenfeld, 1867: 799-800.

Aleurotrachelus jelinekii (Frauenfeld) Fowler, 1954: 406.

Aleurotuba jelinekii (Frauenfeld) Tremblay \& Iaccarino, 1978: 61.

Distribution. Europe and Mediterranean countries: Corfu, Corsica, Crete, England, France, Germany, Greece, Italy, Morocco, Portugal, Rhodes, Sicily, Spain, Turkey, Yugoslavia. Elsewhere in Palaearctic Region: Federation of Independent States. Nearctic Region: USA (California).

Host plants. Caprifoliaceae: Viburnum tinus, Viburnum spp.; Ericaceae: Arbutus unedo, Arctostaphylos uva-ursi; Myrtaceae: Myrtus communis.

Comments. Aleurotuba jelinekii is one of the most common whiteflies across Europe, including in northern localities such as the British Isles (Mound, 1966). It is most frequently encountered on the widely-planted Viburnum tinus, but Arbutus unedo is also favoured, with a few other hosts also recorded.

\section{Genus Aleuroviggianus Iaccarino}

Aleuroviggianus Iaccarino, 1982: 36. Type species Aleuroviggianus adrianae Iaccarino.

Comments. Aleuroviggianus is a pan-Mediterranean genus with six included species, and yet none of these six had been described before the genus was proposed by Iaccarino (1982), to accommodate the single species, A. adrianae. Subsequently, another species was described by BinkMoenen (in Bink-Moenen \& Gerling, 1992), and four more by Bink-Moenen (1992) when she presented the results of a detailed study of this genus of whiteflies which feed only on evergreen oaks. One species had previously been illustrated several times, by Gomez-Menor, but had been erroneously mistaken for Pealius quercus (see Aleuroviggianus polymorphus, below, and discussion of $P$. quercus). The puparial characteristics of the members of this genus are remarkably varied, as can be seen in figs 20-27, and one species also displays marked puparial polymorphism. In contrast, Bink-Moenen found the adults to be strikingly similar, supporting the placing of puparia with disparate characteristics within a single genus. The type species, A. adrianae, is clearly the commonest and most widely distributed species (see below).

\section{Aleuroviggianus adanaensis Bink-Moenen} (fig. 20)

Aleuroviggianus adanaensis Bink-Moenen, 1992: 36-39.

Distribution. Europe and Mediterranean countries: Israel, Rhodes, Syria Turkey.

Host plants. Fagaceae: Quercus calliprinos, Q. coccifera.

\section{Aleuroviggianus adrianae Iaccarino}

(fig. 21)

Aleuroviggianus adrianae Iaccarino, 1982: 38

Distribution. Europe and Mediterranean countries: Corfu, Corsica, Egypt, Italy, France, Morocco, Sardinia, Sicily, Spain.

Host plants. Fagaceae: Quercus ilex, Q. rotundifolia, Q. suber.

\section{Aleuroviggianus graecus Bink-Moenen}

(fig. 22)

Aleuroviggianus graecus Bink-Moenen, 1992: 39.

Distribution. Europe and Mediterranean countries: Corfu, Crete.

Host plants. Fagaceae: Quercus coccifera.

\section{Aleuroviggianus halperini Bink-Moenen (fig. 23)}

Aleuroviggianus halperini Bink-Moenen in Bink-Moenen \& Gerling, 1992 14-16.

Distribution. Europe and Mediterranean countries: Israel, Rhodes, Turkey. Host plants. Fagaceae: Quercus calliprinos, Q. coccifera, Q. ithaburensis.

\section{Aleuroviggianus polymorphus Bink-Moenen} (figs 24-26)

Aleurodes quercus Signoret; Gomez-Menor, 1945: 283-287; 1953: 43, 46; 1958: 135-139 [misidentification].

Aleuroviggianus polymorphus Bink-Moenen, 1992: 27-33.

Distribution. Europe and Mediterranean countries: France, Morocco, Spain. Host plants. Quercus coccifera, Q. ilex, Q. rotundifolia, Q. suber.

\section{Aleuroviggianus zonalus Bink-Moenen}

(fig. 27)

Aleuroviggianus zonalus Bink-Moenen, 1992: 33-36.

Distribution. Europe and Mediterranean countries: Albania, Corfu, Crete, Kos, Rhodes, Turkey.

Host plants. Fagaceae: Quercus coccifera.

\section{Genus Aleyrodes Latreille}

Aleyrodes Latreille, 1796: 93. Type species Phalaena (Tinea) proletella Linnaeus, 1758: 537-538.

Conantulus Goux, 1988: 64-65. Type species Conantulus lacombiensis Goux, 1988: 65 [synonymized by Martin, 1999: 53].

Comments. Our current understanding is that there are four similar species of Aleyrodes occurring in the study area, along with a fifth which is more distinctive. Two of the four similar species are highly polyphagous, but each of the other two is usually associated with just one host. As is the case with Bemisia, species of Aleyrodes display a degree of puparial variation. Bink-Moenen \& Mound (1990) found that, whilst there is a degree of overlap in the puparial characters of these four species, preliminary studies indicated that characters of the adult abdomen may enable more reliable identifications in the future. However, for each of A. asari and $A$. elevatus the characteristics of a typical puparium, on its usual host, should serve to make the species readily recognizable in most circumstances.

\section{Aleyrodes asari (Schrank)} (fig. 28)

Coccus asari Schrank, 1801: 145.

Aleurodes [sic] asari (Schrank) Lindinger, 1932: 223

Distribution. Europe and Mediterranean countries: Albania, Austria, Czechoslovakia, Germany, Hungary, Lithuania, Poland, Romania. Host plants. Aristolochiaceae: Asarum europaeum.

Comments. This species is only known from colonies on a single host plant species. Its rather elongate puparial outline, combined with its usual pattern of six pairs of enlarged dorsal disc setae and occurrence in mealy colonies, renders this species readily recognizable on Asarum europaeum. However, its similarity to some puparia of $A$. lonicerae on other hosts raises a question as to whether asari really is a distinct species.

\section{Aleyrodes elevatus Silvestri}

(fig. 29)

Aleyrodes elevatus Silvestri, 1934: 394-396.

Distribution. Europe and Mediterranean countries: Corsica, France, Israel, Italy, Rhodes, Sicily, Spain, Turkey. Elsewhere in Palaearctic Region: Georgia. 


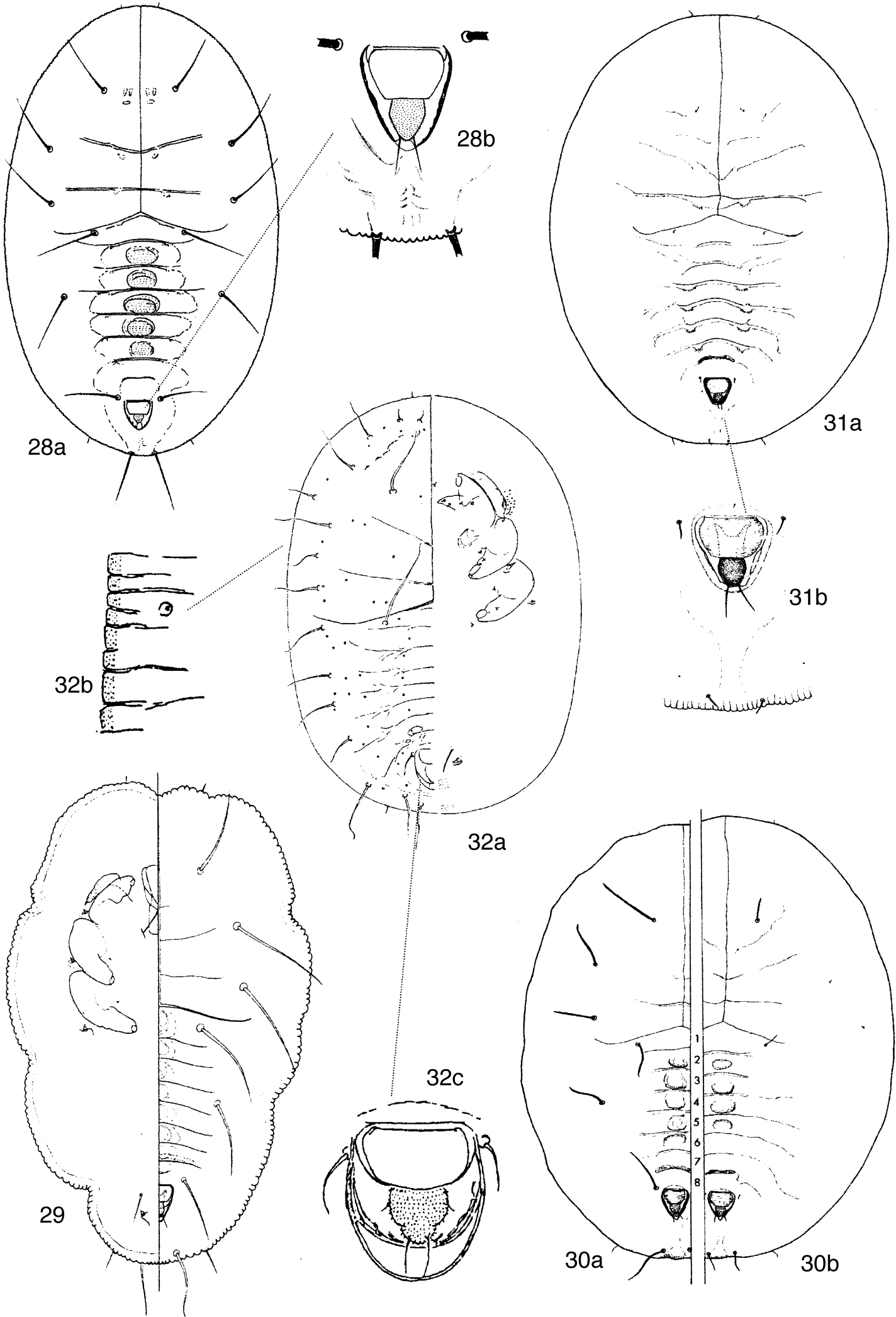

Figs 28-32. 28, Aleyrodes asari, puparium (from Zahradnik, 1989b); 29, Aleyrodes elevatus, puparium (from Patti \& Rapisarda, 1981); 30, Aleyrodes lonicerae, (a) puparium ex-Mentha sp. and (b) ex-Geum sp. (from Martin, 1987); 31, Aleyrodes proletella, puparium (from Martin, 1987); 32, Aleyrodes singularis, puparium (from Bink-Moenen \& Gerling, 1992). 
Host plants. Euphorbiaceae: Mercurialis annua; Moraceae: Ficus carica; Urticaceae: Parietaria officinalis.

Comments. This species usually develops with characteristically tall puparia which are protected laterally by a waxy palisade, and is mos commonly encountered on fig trees, occasionally in enormous numbers. Some puparia have a longitudinal dark band on either side of the median line, but this character is most pronounced in living specimens, and is best viewed with a hand lens. The exuviae of earlier instars usually remain attached to the puparial dorsum, providing a useful secondary recognition character. Puparia of A. elevatus developing on Mercurialis are not readily distinguishable from those of $A$. lonicerae, but their determination as elevatus has been indicated by study of the adults (see generic comments, above).

\section{Aleyrodes lonicerae Walker} (fig. 30)

Aleyrodes lonicerae Walker, 1852: 1092.

Aleyrodes fragariae Walker, 1852: 1092 [synonymized by Ossiannilsson, 1955: 193]

Conantulus lacombiensis Goux, 1988: 65 [synonymized by Martin, 1999 53-54].

Distribution. Europe and Mediterranean countries: Austria, Channel Islands, Corsica, Czechoslovakia, Denmark, England, Finland, France, Germany, Hungary, Isle of Man, Israel, Italy, Morocco, Netherlands, Norway, Poland, Romania, Sicily, Sweden, Switzerland, Turkey, Wales, Yugoslavia. Elsewhere in Palaearctic Region: Federation of Independent States.

Host plants. Recorded on more than 18 different plant families by Mound \& Halsey (1978) and many more since. This species favours herbaceous and woody hosts in the families Caprifoliaceae and Rosaceae.

Comments. This species is widespread throughout Europe and more western parts of Russia. It is polyphagous, although not to such a great extent as other species such as Bemisia tabaci and Trialeurodes vaporariorum. This species is discussed, in literature, under several names now placed in synonymy and Mound \& Halsey (1978) may be consulted for details.

\section{Aleyrodes proletella (Linnaeus)}

(fig. 31)

Phalaena (Tinea) proletella Linnaeus, 1758: 537-538 [in Lepidoptera]. Aleyrodes proletella (Linnaeus) Latreille, 1801-02: 264 [Aleyrodidae] Coccus prenanthis Schrank, 1801: 147 [Coccidae].

Aleyrodes prenanthis (Schrank) Cockerell, 1902: 281 [Aleyrodidae] [synonymized by Klimaszewski \& Szelegiewicz, 1962: 42].

Aleyrodes brassicae Walker, 1852: 1092 [synonymized by Haupt, 1935: 256]

Aleurodes euphorbiae Löw, 1867: 746-747 [synonymized by Zahradnik, 1991: 113].

Distribution. Europe and Mediterranean countries: throughout. Elsewhere in Palaearctic Region: Eurasia, Macaronesia. Ethiopian Region: Angola, Cape Verde Islands, Kenya, Mozambique, South Africa. Oriental Region: Taiwan. Australia: South Australia, Victoria. Pacific Region: New Zealand. Neotropical Region: Brazil. Nearctic Region: eastern USA.

Host plants. Polyphagous, mostly on herbaceous hosts, with a marked preference for Cruciferae and, to a lesser extent, Compositae. Hosts belonging to 12 angiosperm families were listed by Mound \& Halsey (1978) but a record for Ouercus (Fagaceae), attributed to Salaas (1942b) who actually merely quoted Kirkaldy (1907), is almost certainly erroneous.

Comments. The often-called European cabbage whitefly is principally a minor pest of brassica crops, but is found on a range of other hosts, usually those with smooth leaves. Puparial cuticle is usually entirely pale but is sometimes slightly to moderately pigmented, especially in autumn in temperate regions. As is the case with A. lonicerae, $A$. proletella has several synonyms additional to those detailed above and these are listed by Mound \& Halsey (1978).

Schrank (1801), in describing Coccus prenanthis as a scale insect, spoke of the emerging male as having four wings, of which the fore pair were slightly the larger, and described the colour as being whitish: this was sufficient for Cockerell (1902) to place the species in the Aleyrodidae, where it was simply listed without comment. Again, Kirkaldy (1907) simply listed A. prenanthis and made no comments. Harrison (1931) stated that the species was abundant on Prenanthes purpurea in Switzerland but even if his material could be traced, it could not be said with certainty that it was conspecific with the sample upon which Schrank based his brief description. Despite this uncertainty, Klimaszewski \& Szelegiewicz
(1962) placed prenanthis as a junior synonym of proletella but regarding Coccus prenanthis as nomen dubium would have reflected the situation more realistically.

\section{Aleyrodes singularis Danzig \\ (fig. 32)}

Aleyrodes singularis Danzig, 1964: 645 [330].

Distribution. Europe and Mediterranean countries: Jordan, Israel, Syria. Elsewhere in Palaearctic Region: Canary Islands, Federation of Independent States (Georgia), Iran.

Host plants. Campanulaceae: Canarina canariensis; Compositae: Lactuca serriola, Sonchus oleraceus; Cruciferae: Crambe sp.; Euphorbiaceae: Euphorbia spp.

Comments. Lactuca appears to be the preferred host of this species, at least in the Middle East. The puparia often develop in large and very dense colonies under the leaves, with mealy wax being secreted. Samples from Crambe and Canarina in the Canary Islands have been identified following comparison with paratypes in BMNH.

\section{Genus Asterobemisia Trehan}

Asterobemisia Trehan, 1940: 591-593. Type species Aleurodes carpini Koch, 1857: 327.

Bemisia (Neobemisia) Visnya, 1941b: 8. Type species Bemisia yanagicola Takahashi, 1934: 137-139 [synonymized by Mound \& Halsey, 1978: 104].

Comments. As understood here, the genus Asterobemisia includes species with a triangular vasiform orifice, acute lingula head which is exposed but included within the vasiform orifice, and with the transverse moulting sutures curving anteriorly to meet the longitudinal moulting suture, such that adult emergence causes 'trapdoors' to fall away from the puparium. Although there has been discussion by Bink-Moenen \& Mound (1990) of whether A. carpini (without a puparial caudal furrow) is congeneric with the other species occurring in the study area (whose puparia have a well-developed caudal furrow) the resolution of this question is beyond the scope of this work.

\section{Asterobemisia carpini (Koch) (figs 33, 34)}

Aleurodes carpini Koch, 1857: 327

Aleurodes avellanae Signoret, 1868: 385-386 [synonymized by Mound \& Halsey, 1978: 105]

Asterobemisia carpini (Koch) Trehan, 1940: 593

Distribution. Europe and Mediterranean countries: Austria, Bulgaria Czechoslovakia, Denmark, England, Finland, France, Germany, Greece, Hungary, Italy, Netherlands, Poland, Romania, Spain, Sweden, Yugoslavia. Elsewhere in Palaearctic Region: Japan, Federation of Independent States.

Host plants. Polyphagous, with 15 angiosperm plant families listed by Mound \& Halsey (1978). This species clearly favours tree and shrub hosts. Comments. Zahradnik (1989b, 1991) did not accept the synonymy of avellanae with carpini and continued to list them as two separate species. Pending more detailed studies, the synonymy proposed by Mound \& Halsey (1978) is retained here, on the basis of considerable puparial phenotypic variation being likely, as in the Bemisia-group as a whole. This species has appeared in literature under several other names, and a full synonymy was given by Mound \& Halsey (1978).

\section{Asterobemisia obenbergeri (Zahradnik)} (fig. 36)

Neobemisia obenbergeri Zahradnik, 1961: 68-75

Asterobemisia obenbergeri (Zahradnik) Mound \& Halsey, 1978: 106.

Distribution. Europe and Mediterranean countries: Albania, Bulgaria, Czechoslovakia, France, Greece, Hungary, Poland, Yugoslavia.

Host plants. Globulariaceae: Globularia cordifolia; Labiatae: Satureja montana, Thymus spp.

Comments. This species is still only known from the localities quoted in Zahradnik's description and later publications. Asterobemisia obenbergeri can be distinguished from the other European species of Asterobemisia by use of the key. Only three (paratype) puparia of this species have been examined as part of this study but the characteristics of the thoracic tracheal fold sculpture, combined with fine marginal crenulations (see key, couplet 29), serve to define A. obenbergeri as currently understood. 

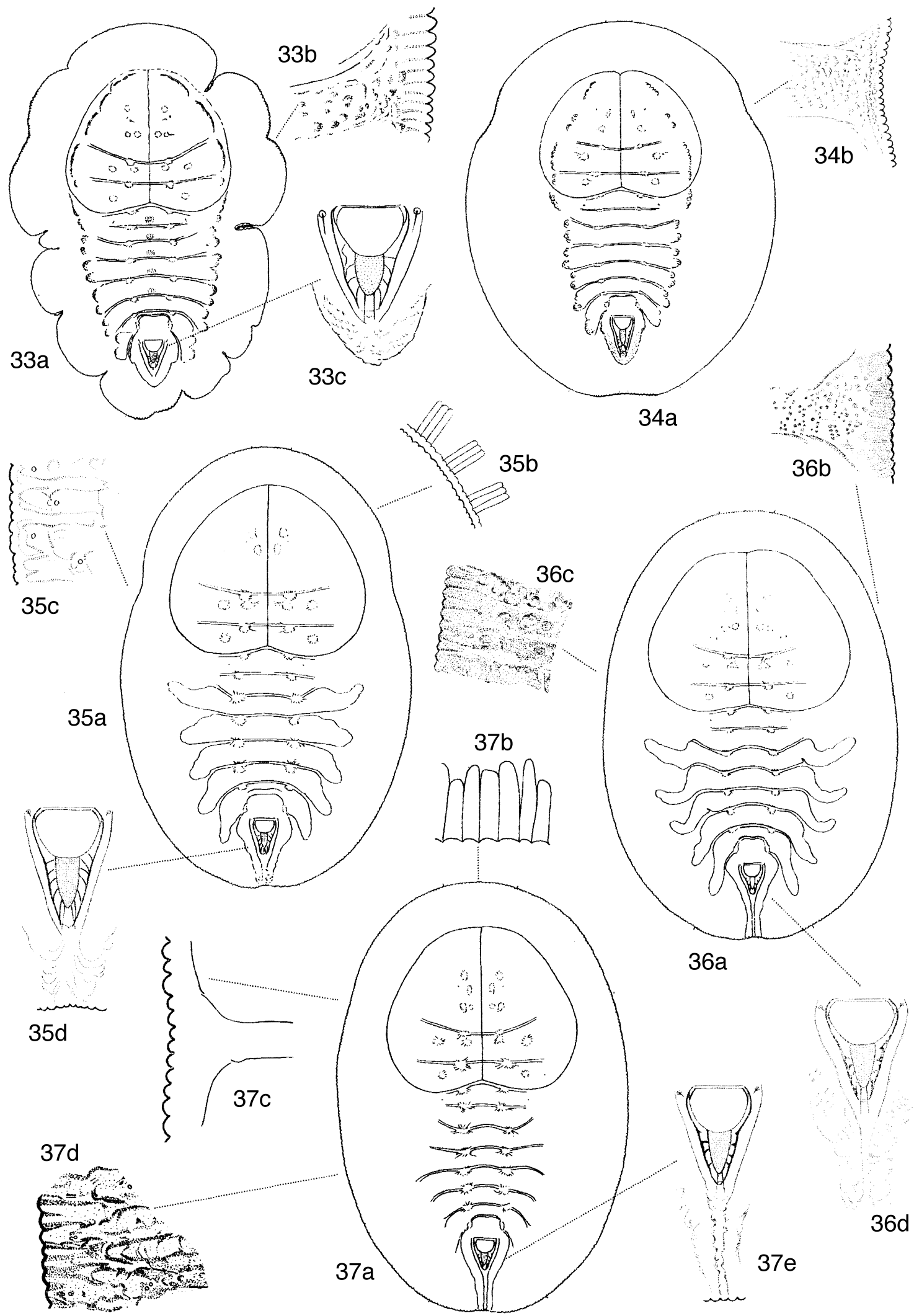

Figs 33-37, Asterobemisia spp., puparia (from Zahradnik, 1989b). 33, A. carpini, from hairy leaf; 34, A. carpini, from smooth leaf; 35 , A. paveli (original figure of $A$. nigrini); 36, A. obenbergeri; 37, A. paveli. 


\section{Asterobemisia paveli (Zahradnik)}

$$
\text { (figs 35, 37) }
$$

Neobemisia paveli Zahradnik, 1961: 75-78.

Asterobemisia paveli (Zahradnik) Mound \& Halsey, 1978: 107.

Asterobemisia nigrini Zahradnik, 1987a: 350-352. Syn. n.

Distribution. Europe and Mediterranean countries: Czechoslovakia, Germany, Hungary, Israel, Romania, Spain.

Host plants. Euphorbiaceae: Euphorbia spp.; Leguminosae: Genista pilosa; Thymelaeaceae: Daphne gnidium.

Comments. The published records of this species refer to its host plants as being species of Euphorbia (Zahradnik, 1961; Dobreanu \& Manolache, 1969). A colony was discovered in Spain in 1998, on a plant closely resembling Euphorbia but positively identified as Daphne gnidium. The proposal to place A. nigrini as a junior synonym of $A$. paveli (see below) provides a third host plant family for this species.

The characters distinguishing A. nigrini from A. paveli were described as: marginal fringe comprising discrete 'fingers' of wax (fig. 35b), rather than a continuous ring of such wax, the tracheal folds being wider, the caudal furrow shorter than or equal to length of vasiform orifice, and the development of the larvae and puparia on the upper surfaces of the leaves. Paratypes of $A$. paveli were compared at a late stage of manuscript preparation with the holotype and one paratype of $A$. nigrini. The pavel paratypes have their caudal furrows subequal to vasiform orifice length A sample of puparia collected on Daphne gnidium in Spain contains a mixture of individuals with the marginal wax fringe appearing castellate, as in Zahradnik's (1987a) photograph of nigrini, and others with a more continuous fringe; the puparia of this sample also display variations in the width of the thoracic tracheal folds, even varying on opposite sides of a single specimen; the individuals of this same sample have the caudal furrow length varying from longer than to equal to vasiform orifice length. Although the type specimens of $A$. nigrini were unusual, feeding on the upper surfaces of the leaves of their host, there are apparently no morphological characters that reliably define nigrini and it is here regarded as a synonym of $A$. paveli.

\section{Genus Bemisia Quaintance \& Baker}

Bemisia Quaintance \& Baker, 1914: 99-100. Type species Aleurodes inconspicua Quaintance, 1900: 28-29 [synonymized with Aleurodes tabaci Gennadius, 1889: 1-3 by Russell, 1957: 122].

Cortesiana Goux, 1988: 63-64. Type species Cortesiana restonicae Goux, 1988: 64 [synonymized by Martin, 1999: 54].

\section{Bemisia afer (Priesner \& Hosny) (figs 38, 39)}

Dialeurodoides afer Priesner \& Hosny, 1934b: 6. Bemisia hancocki Corbett, 1936: 20 [synonymized by Bink-Moenen, 1983: 95].

Bemisia citricola Gomez-Menor, 1945: 293-298 [synonymized by Mound \& Halsey, 1978: 114]

Bemisia afer (Priesner \& Hosny) Habib \& Farag, 1970: 8-10.

Distribution. Europe and Mediterranean countries: Corsica, Egypt, [England], France, Greece, Israel, Italy, Malta, Rhodes, Sicily, Spain, Turkey. Elsewhere: widely distributed in warmer parts of the world, but see comments, below.

Host plants. Polyphagous. Hosts belonging to 20 plant families, mostly dicots, listed by Mound \& Halsey (1978), but see comments, below.

Comments. Although B. hancocki was proposed as a junior synonym of $B$. afer by Bink-Moenen (1983), continuing studies indicate that the degree of puparial morphological variation, within and between populations of this group, remains poorly understood. This synonymy has been subject to comment by Martin $(1987,1999)$ but detailed studies of this group, using a variety of techniques, will be needed before the situation may be resolved.

Future studies using modern taxonomic techniques may clarify the status of several existing species names in this complex. Within the Europe-Mediterranean area the following species names are also available within this species-group: B. citricola Gomez-Menor (1945), B. ovata (Goux, 1940) and B. spiraeoides Mound \& Halsey (1978). Similar studies will also be needed to clarify the status of a remarkable variety of puparial 'morphs' recently discovered in most of the islands of Macaronesia (see appendix 1)

Although material of several English samples are present in $\mathrm{BMNH}$ they all concern colonies contaminating glasshouses.

\section{Bemisia tabaci (Gennadius)}

(figs 40-42)

Aleurodes tabaci Gennadius, 1889: 1-3

Bemisia tabaci (Gennadius) Takahashi, 1936: 110.

Cortesiana restonicae Goux, 1988: 64 [synonymized by Martin, 1999: 59]

Distribution. Europe and Mediterranean countries: throughout, but usually found under glass in areas with continental climate. Elsewhere: cosmopolitan in all warmer parts of the world.

Host plants. Bemisia tabaci is extremely polyphagous, reported to occur on hundreds of different plant species (Mound \& Halsey, 1978; Greathead, 1986).

Comments. Variation of puparial morphology was apparently recognized by Russell (1957), who published a paper placing nine Bemisia species in synonymy with $B$. tabaci, on the basis of having compared types and topotypes of the species concerned. Mound (1963) published supporting experimental evidence of this puparial variability, such variation usually correlating with physical characteristics of leaf surfaces and having implications for the study of all whiteflies. As a result of these publications, identifying puparia of $B$. tabaci became relatively easy, with the key puparial characters illustrated and discussed by Mound (1965), Patti \& Rapisarda (1981) and by Martin (1987), and the variability of subdorsal setae and tubercles no longer caused confusion. However, the recognition of biotypes of $B$. tabaci in the 1980s, and their ensuing study, has caused the situation with $B$. tabaci to become complex once again.

Nowadays, several biotypes have been recognized (Bedford et al., 1994; Guirao et al., 1997; De Barro et al., 1998), through the use of non-specific esterase banding pattern analysis and, more recently, techniques such as RAPD-PCR sequencing of DNA. Although such biotypes can be characterized by various means, none can be definitely distinguished from other tabaci biotypes by morphological examination alone. The description of the B biotype as a separate species, Bemisia argentifolii (the 'silverleaf whitefly'), by Bellows \& Perring (in Bellows et al., 1994) provided a species name for a taxon that can only be determined by means other than visual examination. This has always been controversial, but recent research has led to the conclusion that $B$. tabaci and B. argentifolii are members of a highly cryptic species complex (Rosell et al., 1997; Frolich et al., 1999). In such a situation opinion is moving strongly towards the view that, if silverleaf whitefly is to retain its own specific name, then other biotypes of $B$. tabaci would eventually need to be treated similarly (De Barro et al., 2000). The current situation provides unfortunate nomenclatural complication, with the terms 'biotype B' [of B. tabaci] and 'B. argentifolii' both widely used for the same entity, sometimes even within individual publications (discussions at meetings of the European Whitefly Studies Network, Norwich, May 1999 and May 2000). However, given the ascendency of the species-complex theory, the present authors consider that proposing $B$. argentifolii as a synonym of $B$. tabaci (often discussed) would be equally unjustified at a time when our knowledge is moving forward so rapidly.

Bemisia tabaci is known to transmit geminiviruses to cultivated plants belonging to various families, especially Cucurbitaceae, Leguminosae, Euphorbiaceae, Malvaceae and Solanaceae (Bedford et al., 1994), and is a serious pest of both open-air and protected cropping (for example, in Spain and Israel in the Europe-Mediterranean area). The impact of $B$. tabaci on world agriculture has led to the expenditure of much research effort on this species and its biotypes, and an extensive literature on $B$. tabaci was listed by Cock $(1986,1993)$. There have been many specialist papers on aspects of $B$. tabaci research published subsequently, of which notable systematic/phylogenetic examples are discussed above.

\section{Genus Bulgarialeurodes Corbett}

Bulgarialeurodes Corbett, 1936: 18. Type species Bulgarialeurodes rosae Corbett, 1936: 18 [synonymized with Aleurodes cotesii Maskell, 1896: 427-428 by Russell, 1960: 30]

\section{Bulgarialeurodes cotesii (Maskell) (fig. 43)}

Aleurodes cotesii Maskell, 1896: 427-428.

Bulgarialeurodes rosae Corbett, 1936:18 [synonymized by Russell, 1960: 30]. Bulgarialeurodes cotesii (Maskell) Russell, 1960: 30-32.

Distribution. Europe and Mediterranean countries: Bulgaria, Hungary, Romania, Turkey, Yugoslavia. Elsewhere in Palaearctic Region: Afghanistan, Iran, Federation of Independent States. Oriental Region: Pakistan.

Host plants. Rosaceae: Rosa damascena; Rosa sp. 


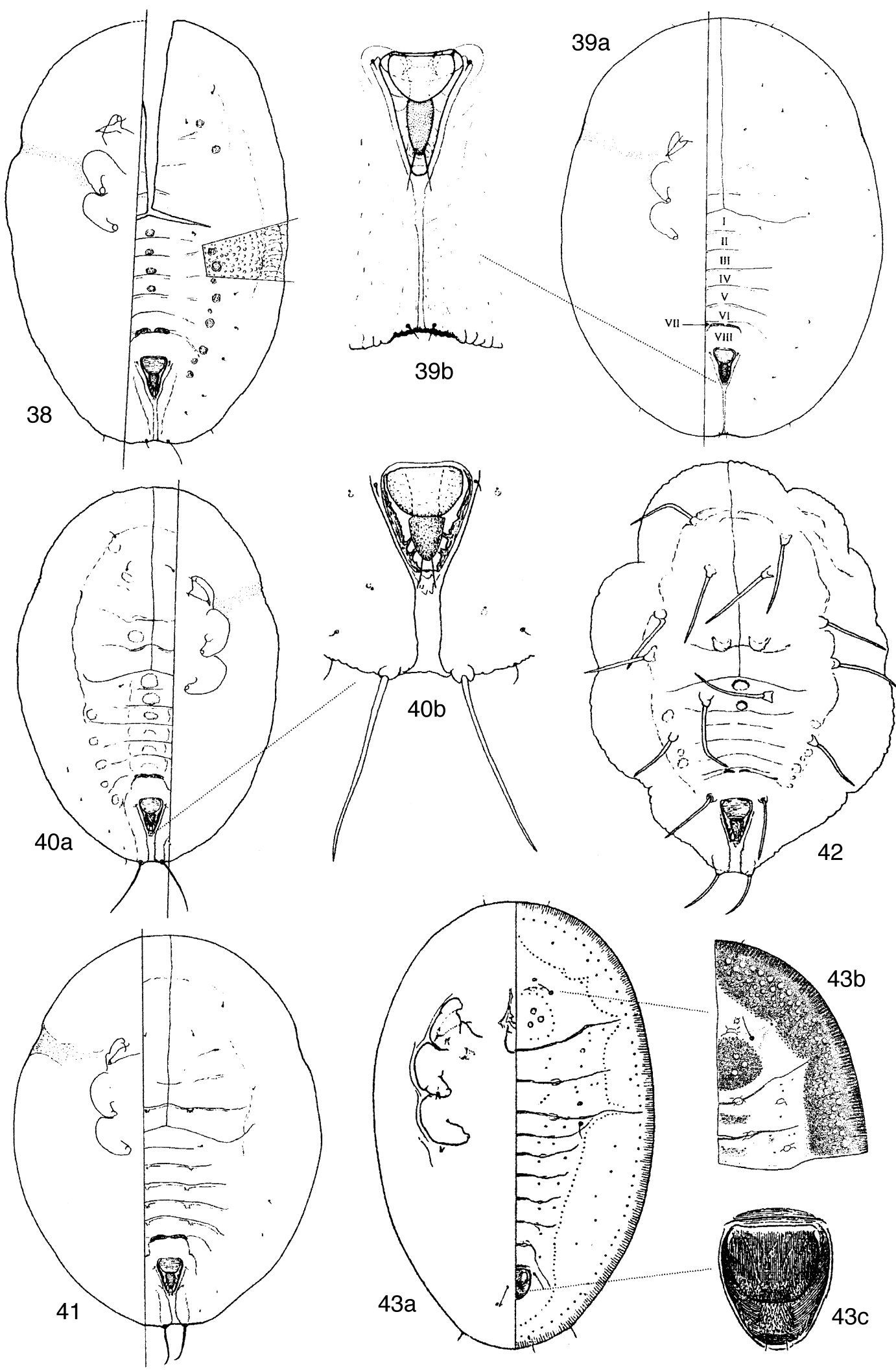

Figs 38-43. 38-42, Bemisia spp., puparia (from Martin, 1987). 38-39, B. afer, variants; 40-42, B. tabaci, variants (40) ex-Aciotis, (41) exCanavalia, (42) ex-Sophora; 43, Bulgarialeurodes cotesii, puparium (from Russell, 1960). 
Comments. This species is apparently uncommon and only found in small numbers when it is detected. The puparia secrete dense dorsal curls of wax, but the individuals remain unobtrusive through being widely scattered

\section{Genus Calluneyrodes Zahradnik}

Calluneyrodes Zahradnik, 1961: 65-66. Type species Bemisia callunae Ossiannilsson, 1947: 1-3

\section{Calluneyrodes callunae (Ossiannilsson) (fig. 44)}

Bemisia callunae Ossiannilsson, 1947: 1-3.

Calluneyrodes callunae (Ossiannilsson) Zahradnik, 1961: 65.

Distribution. Europe and Mediterranean countries: Czechoslovakia, Finland, Portugal, Sweden.

Host plants. Ericaceae: Calluna vulgaris, Calluna sp.; Erica arborea, Erica sp.

Comments. The puparia of this species are exceptionally difficult to see on the leaves of their host plants, possibly leading to the paucity of records of this interesting whitefly.

\section{Genus Dialeurodes Cockerell}

Aleyrodes (Dialeurodes) Cockerell, 1902: 283. Type species Aleyrodes citri Riley \& Howard 1893: 219-222 [synonymized with Aleyrodes citri Ashmead, 1885: 704 by Quaintance \& Baker, 1917: 408].

Dialeurodes Cockerell, Quaintance \& Baker, 1914: 97.

Comments. With our current understanding of puparial systematics Dialeurodes is the most speciose whitefly genus, by a considerable margin, with over 140 species currently included worldwide (Martin, 1999). Jensen (1999) chose a selection of species of Dialeurodes sensu lato for a preliminary cladistic study of whitefly puparia. His results have indicated, for the first time, that such an approach to puparial systematics is entirely practicable, clearly indicating discrete groupings within the assemblage. In a subsequent development of his study, Jensen (in press) will present data providing a clearer separation of Dialeurodes from Singhiella and Massilieurodes. Within Europe and the Mediterranean area, four species are included within Dialeurodes sensu lato.

\section{Dialeurodes chittendeni Laing}

(fig. 45)

Dialeurodes chittendeni Laing, 1928: 228-230.

Distribution. Europe and Mediterranean countries: Belgium, Czechoslovakia, Denmark, England, Finland, Germany, Italy, Netherlands, Sweden, Switzerland.

Host plants. Ericaceae: Rhododendron spp.

Comments. Although clearly a member of Dialeurodes sensu lato, this species may prove not to be congeneric with the type species of Dialeurodes, and studies are continuing (A. Jensen, personal communication). Despite having been described from England, it is probable that $D$. chittendeni originates in northern Asia, from where many rhododendrons also originate.

\section{Dialeurodes citri (Ashmead)} (figs 46, 47)

Aleyrodes citri Ashmead, 1885: 704

Dialeurodes citri (Ashmead) Quaintance \& Baker, 1916: 469.

Distribution. Europe and Mediterranean countries: Algeria, Corsica, Egypt, France, Greece, Israel, Italy, Lebanon, Malta, Morocco, Sardinia Sicily, Spain, Tunisia, Turkey, Yugoslavia. Elsewhere in Palaearctic Region Japan, Federation of Independent States. Oriental Region: China, Hong Kong, India, Pakistan, Sri Lanka, Taiwan, Thailand. Neotropical Region: Argentina. Nearctic Region: USA (Florida)

Host plants. Dialeurodes citri is known to occur on numerous angiosperm plant families (Mound \& Halsey, 1978), but is almost always associated with Citrus in the Mediterranean area.

Comments. This species is now distributed widely through warmer temperate areas, where it often becomes a serious pest of citrus crops.
Dialeurodes citri has several junior synonyms (Mound \& Halsey, 1978). It is probable that $D$. citri is a native of the Oriental Region, from where several puparial variants are known, but it remains uncertain whether these are simply examples of intra-specific variation of the sort commonly observed in, for example, Bemisia species.

\section{Dialeurodes kirkaldyi (Kotinsky) \\ (figs 48,49 )}

Aleyrodes kirkaldyi Kotinsky, 1907: 95-96.

Dialeurodes kirkaldyi (Kotinsky) Quaintance \& Baker, 1914: 98.

Distribution. Europe and Mediterranean countries: Cyprus, Egypt, Israel, Lebanon, Portugal, Syria. Elsewhere in Palaearctic Region: Azores, Japan. Ethiopian Region: Djibouti, Ghana, Ivory Coast, Kenya. Oriental, Austrooriental and Pacific Regions: widely distributed. Nearctic Region: USA (Florida).

Host plants. Feeding on woody hosts, with 17 genera in ten dicotyledonous families listed by Russell (1964), but its favoured hosts are Jasminum spp. (Oleaceae) and Morinda citrifolia (Rubiaceae).

Comments. Dialeurodes kirkaldyi is a frequent quarantine intercept, especially at ports in the USA (Russell, 1964). Although described from Hawaii, its area of origin is uncertain.

\section{Dialeurodes setiger (Goux)}

(fig. 50)

Aleuroplatus (Massilieurodes) setiger Goux, 1939: 81-82.

Dialeurodes setiger (Goux) Rapisarda, 1999: 202.

Distribution. Europe and Mediterranean countries: Corfu, Corsica, France, Italy, Morocco, Spain.

Host plants. Caprifoliaceae: Viburnum tinus; Ericaceae: Arbutus unedo.

Comments. This species clearly belongs to Dialeurodes sensu lato and, yet, its original placement, in Aleuroplatus, remained for 60 years. Jensen (in press) reports on a completed study in which evidence will be presented for the reinstatement of Massilieurodes as a full genus within the Dialeurodes group.

The extremely long subdorsal setae, which Goux considered a major diagnostic characteristic of this species, are present only sometimes and many specimens have been seen which bear only very short dorsal setae (personal observations).

\section{Genus Dialeurolobus Danzig}

Dialeurolobus Danzig, 1964: 634-635 [326]. Type species Dialeurolobus pulcher Danzig, 1964: 635 [326].

\section{Dialeurolobus rhamni Bink-Moenen}

(fig. 51)

Dialeurolobus rhamni Bink-Moenen, in Bink-Moenen \& Gerling, 1992: 26-28.

Distribution. Europe and Mediterranean countries: Israel, Turkey. Elsewhere in Palaearctic Region: Iran, Iraq.

Host plants. Lythraceae: Punica granatum; Rhamnaceae: Rhamnus palaestina. [Rosaceae: Rosa canina].

Comments. Although described from specimens feeding on Rhamnus palaestina, there are several samples in BMNH, London, which were collected from pomegranate and have been identified in comparison with paratype material of D. rhamni. Five pale Dialeurolobus puparia, collected from Rosa canina in Turkey, have been tentatively identified as D. rhamni, with their apparent absence of first abdominal setae: the lack of sclerotization of these specimens may possibly be varietal (see discussion of Aleurotrachelus rhamnicola, here and by Martin et al., 1996) or, alternatively, be the result of parasitism (a well-developed parasitoid is visible in one individual). It is possible that $D$. rhamni may eventually prove to be a synonym of $D$. pulcher Danzig.

\section{Genus Neopealius Takahashi}

Neopealius Takahashi, 1954: 50-51. Type species Neopealius rubi Takahashi, 1954: 51-52. 


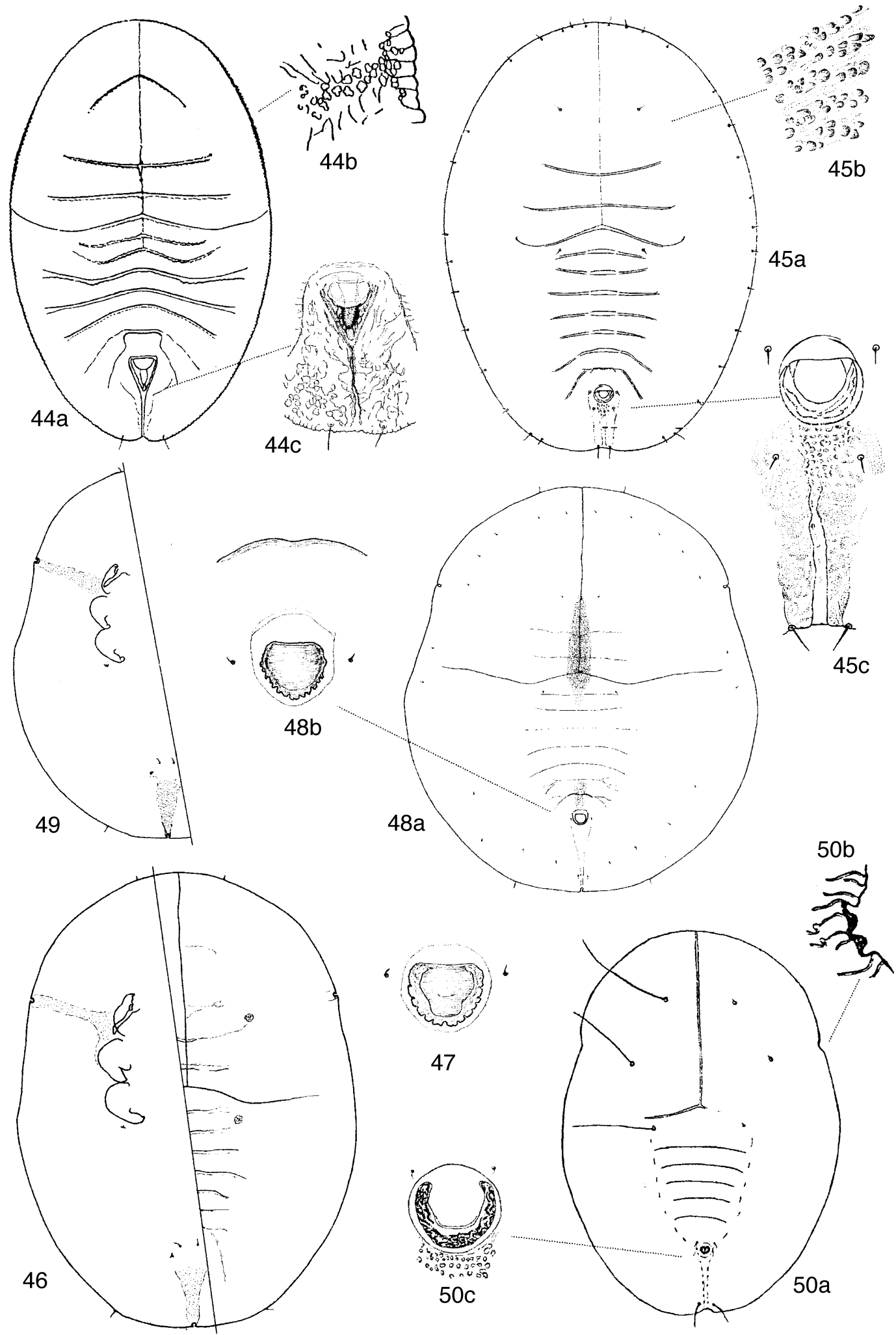

Figs 44-50. 44, Calluneyrodes callunae, puparium (adapted from Zahradnik, 1985 and Ossiannilsson, 1947); 45, Dialeurodes chittendeni, puparium (from Zahradnik, 1987b); 46, Dialeurodes citri, puparium (from Martin, 1987); 47, Dialeurodes citri, vasiform orifice (from Martin, 1987); 48, Dialeurodes kirkaldyi, puparial dorsum with pigmentation (from Martin, 1999); 49, Dialeurodes kirkaldyi, puparial venter (adapted from Martin, 1987); 50, Dialeurodes setiger, puparium with long setae shown to left and short setae to right (adapted from Goux, 1939). 


\section{Neopealius rubi Takahashi}

(fig. 52)

Neopealius rubi Takahashi, 1954: 51-52.

Aleyrodes rosae Korobitsin, 1967: 510-511 [synonymized by Bink-Moenen, 1991: 32].

Bemisia rosae Danzig, 1969: 870 [553] [synonymized with Aleyrodes rosae Korobitsin (1967) by Huldén, 1986: 12]

Bemisia rosae (Korobitsin) Huldén, 1986: 12; Gertsson, 1987: 88.

Distribution. Europe and Mediterranean countries: Bulgaria, Finland, France, Hungary, Poland, Sweden, Turkey. Elsewhere in Palaearctic Region: Japan, Federation of Independent States.

Host plants. Dicotyledonous woody plants in seven families listed by Bink-Moenen (1991), but the rosaceous genera Rubus and Rosa are the preferred hosts and, subsequently, specimens have been found on Crataegus monogyna in Turkey.

Comments. In eastern Europe, this species was first placed in Aleyrodes [rosae Korobitsin] and then Bemisia [rosae Danzig], but Bink-Moenen (1991) recognized it as Takahashi's Neopealius rubi, as well as recording this species from Europe for the first time.

\section{Genus Parabemisia Takahashi}

Parabemisia Takahashi, 1952: 21-22. Type species Parabemisia maculata Takahashi, 1952: 22-23.

\section{Parabemisia myricae (Kuwana)}

(fig. 53)

Bemisia myricae Kuwana, 1927: 249-251.

Parabemisia myricae (Kuwana) Takahashi, 1952: 24.

Distribution. Europe and Mediterranean countries: Crete, Cyprus, Egypt, Greece, Israel, Italy, Sardinia, Sicily, Spain, Tunisia, Turkey. Elsewhere in Palaearctic Region: Canary Islands, Japan. Ethiopian Region: Ivory Coast. Oriental Region: Hong Kong India, Sri Lanka, Taiwan. Austro-oriental Region: Malay Peninsula. Pacific Region: Hawaii. Neotropical Region (USA quarantine interceptions): Mexico, Trinidad. Nearctic Region: USA (California, Florida).

Host plants. Recorded from woody dicotyledonous hosts in 14 families by Mound \& Halsey (1978). In the Mediterranean area, avocado and citrus crops are the major hosts.

Comments. Originally described from (and probably native to) Japan, this species has become a pest in several disjunct parts of the world and is widely distributed across the Mediterranean Basin. The common name Japanese bayberry whitefly is often applied. Despite its polyphagy, $P$. myricae particularly favours citrus and avocados in the study area.

\section{Genus Pealius Quaintance \& Baker}

Pealius Quaintance \& Baker, 1914: 99. Type species Aleurodes maskelli Bemis, 1904: 524-525.

Odontaleyrodes Takahashi, 1954: 49-50. Type species Aleyrodes akebiae Kuwana, 1911: 622-623 [synonymized by Martin, 1999: 91].

\section{Pealius azaleae (Baker \& Moles) (fig. 54)}

Aleyrodes azaleae Baker \& Moles, 1920: 81-83.

Pealius azaleae (Baker \& Moles) Takahashi, 1954: 50.

Distribution. Europe and Mediterranean countries: Belgium, England Italy, Netherlands, Scotland. Elsewhere in Palaearctic Region: Madeira, Japan, Federation of Independent States. Oriental Region: India, Taiwan. Australia: Australian Capital Territory, Victoria. Pacific Region: New Zealand. Nearctic Region: Canada.

Host plants. Ericaceae: Rhododendron spp.

Comments. Originally described from Belgian material intercepted by quarantine officials in the USA, this species may have originated in eastern Asia (Martin, 1999). Pealius azaleae is mainly known as a minor pest of ornamental azaleas (Rhododendron spp.). The occurrence of this species in Europe is sporadic, and records may reflect newly introduced populations on each occasion, with its azalea hosts usually being kept indoors, in greenhouses or in very sheltered yards.

\section{Pealius quercus (Signoret)}

(fig. 55)

Aleurodes quercus Signoret, 1868: 384-385.

Pealius quercus (Signoret) Trehan, 1939: 266.

Distribution. Europe and Mediterranean countries: Austria, Czechoslovakia, Denmark, England, Finland, France, Germany, Hungary, Ireland, Lithuania, Netherlands, Poland, Romania, Scotland, [Spain], Sweden, Wales. Elsewhere in Palaearctic Region: Federation of Independent States.

Host plants. Betulaceae and deciduous Fagaceae - recorded from several hosts by Mound \& Halsey (1978).

Comments. Pealius quercus is a predominantly northern and central European species. Records of $P$ quercus from Spain (it was described and illustrated by Gomez-Menor, 1945, 1958 and illustrated in 1953) for the most part clearly concern Aleuroviggianus polymorphus, subsequently described by Bink-Moenen (1992), which feeds on Gomez-Menor's quoted host, Ouercus ilex (an evergreen oak). However, Gomez-Menor (1953) confusingly stated that this species was found ('only') on deciduous oak ('roble') and on evergreen oak ('encina') [in Spain], and also on Corylus avellana beyond Spain. The present authors feel that, whilst it is extremely unlikely that $P$. quercus feeds on Mediterranean evergreen oaks, Gomez-Menor's (1953) Spanish record on deciduous oak may be correct, but requires confirmation.

\section{Genus Simplaleurodes Goux}

Simplaleurodes Goux, 1945: 186. Type species Simplaleurodes hemisphaerica Goux, 1945: 186-197.

\section{Simplaleurodes hemisphaerica Goux}

(figs 56,57 )

Simplaleurodes hemisphaerica Goux, 1945: 186-197.

Distribution. Europe and Mediterranean countries: Corfu, Corsica, Crete, France, Italy, Morocco, Spain

Host plants. Oleaceae: Phillyrea spp.

Comments. With its almost circular and extremely convex black puparia (which often split when placed under a microscope slide coverslip), $S$. hemisphaerica is immediately recognizable. However, its flat third-instar larvae (fig. 56) are sometimes mistaken for puparia if the leg characteristics of the third-instar (see Materials, methods and terminology) are overlooked. This species is only known from the Mediterranean Basin.

\section{Genus Siphoninus Silvestri}

Siphoninus Silvestri, 1915: 245-247. Type species Siphoninus finitimus Silvestri, 1915: 247-249 [synonymized with Aleyrodes phillyreae Haliday, 1835: 119-120 by Mound \& Halsey 1978: 192]

\section{Siphoninus immaculatus (Heeger)}

(fig. 58)

Aleurodes immaculata Heeger, 1856: 33-36.

Siphoninus immaculata (Heeger) Trehan, 1940: 601

Distribution. Europe and Mediterranean countries: Austria, Czechoslovakia, England, Germany, Hungary, Ireland, Isle of Man, Italy, Sweden, Switzerland, Wales. Elsewhere in Palaearctic Region: Federation of Independent States.

Host plants. Araliaceae: Hedera helix.

Comments. Siphoninus immaculatus is only known from a single host plant, and is not commonly encountered although it is widely distributed in continental Europe.

\section{Siphoninus phillyreae (Haliday) (fig. 59)}

Aleyrodes phillyreae Haliday, 1835: 119-120. Siphoninus phillyreae (Haliday) Silvestri, 1915: 247.

Distribution. Europe and Mediterranean countries: throughout, except Scandinavia. Elsewhere in Palaearctic Region: Macaronesia and widely distributed across the Middle East and parts of Russia. Ethiopian Region: Cameroun, Eritrea, Sudan. Oriental Region: India, Pakistan. Australia: 

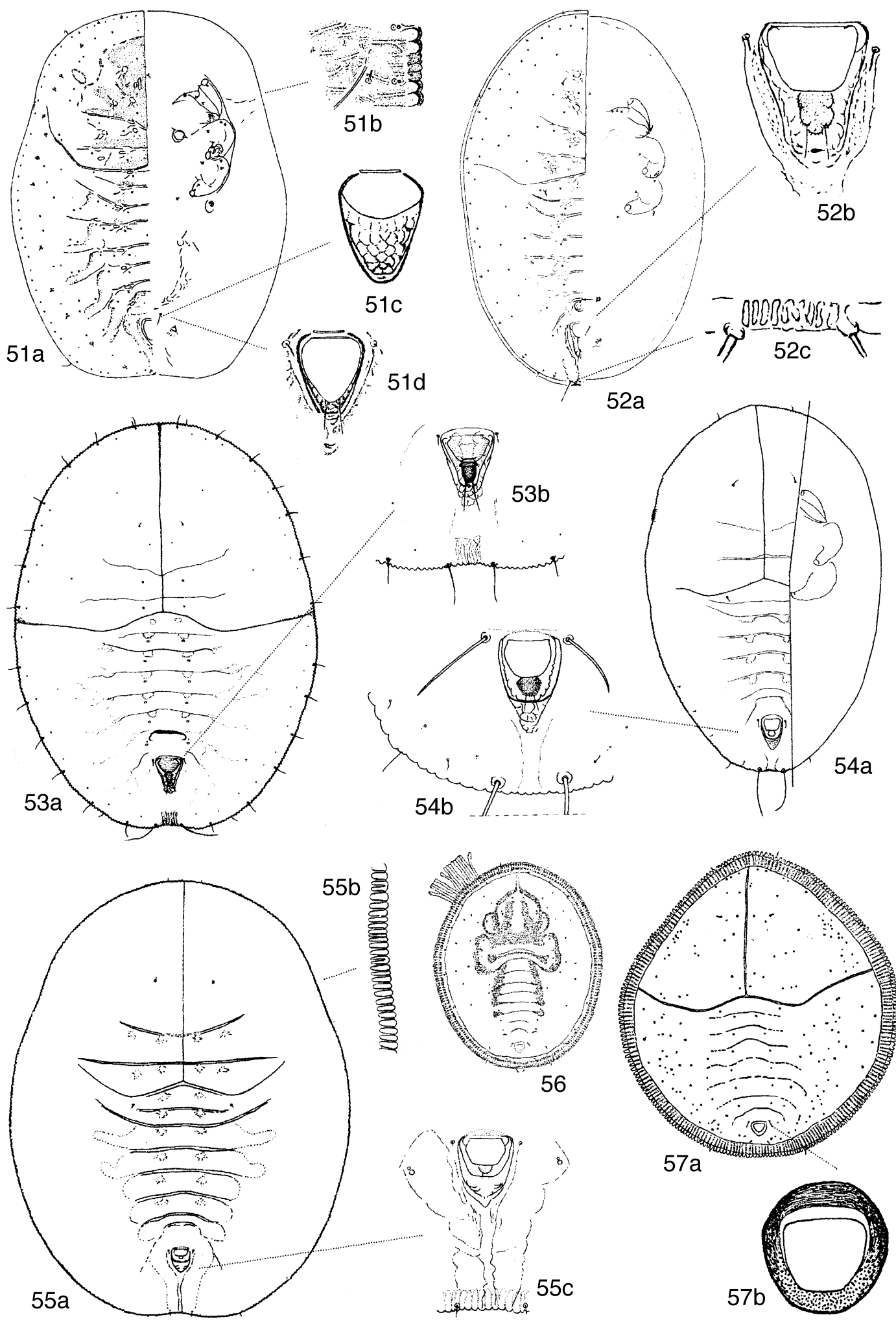

Figs 51-57. 51, Dialeurolobus rhamni, puparium (from Bink-Moenen \& Gerling, 1992)); 52, Neopealius rubi, puparium (adapted from BinkMoenen, 1991); 53, Parabemisia myricae, puparium (from Martin, 1987); 54, Pealius azaleae, puparium (from Martin, 1999); 55, Pealius quercus, puparium (from Zahradnik, 1987b); 56, Simplaleurodes hemisphaerica, third-instar larva (from Goux, 1945); 57, Simplaleurodes hemisphaerica, puparium (from Goux, 1945). 
New South Wales, South Australia. Pacific Region: New Zealand. Neotropical Region: Mexico. Nearctic Region: USA (California).

Host plants. Oligophagous but preferring woody hosts in the Oleaceae, Lythraceae [= Punicaceae] and Rosaceae, particularly Crataegus, Fraxinus, Olea, Phillyrea and Pyrus. Citrus is a recorded host.

Comments. Sometimes known as the ash whitefly, S. phillyreae is a native of the Mediterranean Basin, and infrequently causes problems to agriculturalists there. However, when first introduced into new geographical areas, this species has sometimes caused severe problems (Sorensen et al., 1990) before being brought under control by the introduction of natural enemies. It was first discovered in Australia in 1998, where it caused considerable impact in the Adelaide area of South Australia (Martin, 1999).

The variable number of dorsal puparial siphons has been the cause of a proliferation of species names in Siphoninus, but most have been proposed as synonyms of S. phillyreae, as detailed by Mound \& Halsey (1978).

\section{Genus Tetraleurodes Cockerell}

Aleyrodes (Tetraleurodes) Cockerell, 1902: 283. Type species Aleyrodes (Tetraleurodes) perileuca Cockerell, 1902: 283.

Tetraleurodes Cockerell; Quaintance \& Baker, 1914: 107-108.

\section{Tetraleurodes bicolor Bink-Moenen}

Tetraleurodes bicolor Bink-Moenen, in Bink-Moenen \& Gerling, 1992: 32-33. Distribution. Europe and Mediterranean countries: Israel, Turkey.

Host plants. Myrtaceae: Myrtus communis.

Comments. This species has only been recorded colonizing Myrtus communis, and is apparently native to the eastern Mediterranean Basin.

\section{Tetraleurodes hederae Goux}

(fig. 61)

Tetraleurodes hederae Goux, 1939: 77-80.

Distribution. Europe and Mediterranean countries: France, Italy, Malta Sicily. Elsewhere in Palaearctic Region: Federation of Independent States. Host plants. Araliaceae: Hedera helix.

Comments. More widely distributed within the Mediterranean Basin than is T. bicolor, this species has always been recorded feeding on Hedera.

\section{Tetraleurodes neemani Bink-Moenen} (fig. 62)

Tetraleurodes neemani Bink-Moenen, in Bink-Moenen \& Gerling, 1992: 34-36. Distribution. Europe and Mediterranean countries: Cyprus, Israel, Lebanon, Rhodes, Syria, Turkey.

Host plants. Anacardiaceae: Pistacia palaestina; Caprifoliaceae: Viburnum tinus; Ericaceae: Arbutus andrachne; Lauraceae: Laurus nobilis Leguminosae: Cercis siliquatrum; Myrtaceae: Myrtus communis; Rhamnaceae: Rhamnus alaternus; Rutaceae: Citrus limon; Vitaceae: Vitis sp. Comments. Described as recently as 1992, this species displays a degree of polyphagy and may feed on other woody dicots in the eastern Mediterranean and Middle East area.

\section{Genus Tetralicia Harrison}

Tetralicia Harrison, 1917: 60. Type species Tetralicia ericae Harrison, 1917: 61-62.

\section{Tetralicia ericae Harrison}

Tetralicia ericae Harrison, 1917: 61-62.

Distribution. Europe and Mediterranean countries: Austria, Corsica, Corfu, Crete, Czechoslovakia, Denmark, England, France, Germany, Italy, Mallorca, Malta, Netherlands, Portugal, Scotland, Sicily, Spain, Sweden, Switzerland, Wales.

Host plants. Ericaceae: Erica spp.

Comments. This is a very common and widespread European whitefly species but, despite their black coloration, its tiny, elongate, puparia are difficult to detect, being located on the undersides of very narrow and laterally down-curled leaves.

\section{Tetralicia iberiaca Bink-Moenen}

(fig. 64)

Tetralicia iberiaca Bink-Moenen, 1989: 178-180.

Distribution. Europe and Mediterranean countries: Portugal, Spain.

Host plants. Ericaceae: Erica arborea, E. lusitanica.

Comments. This species has only been recorded from the south-western part of the Iberian peninsula, and its puparia may be distinguished from those of the much more common and widespread T. ericae by their broader outline.

\section{Genus Trialeurodes Cockerell}

Aleyrodes (Trialeurodes) Cockerell, 1902: 283. Type species Aleurodes pergandei Quaintance, 1900: 31-32.

Trialeurodes Cockerell; Quaintance \& Baker, 1915: xi.

\section{Trialeurodes ericae Bink-Moenen} (figs 65, 67)

Trialeurodes ericae Bink-Moenen, 1976: 17-19.

Distribution. Europe and Mediterranean countries: Corsica, Crete, England, France, Italy, Mallorca, Netherlands, Portugal, Spain.

Host plants. Ericaceae: Erica spp.

Comments. Trialeurodes ericae is apparently monophagous on Erica, but appears to have been previously overlooked, to judge from the extensive list of recorded countries presented by Bink-Moenen (1989). In particular, Bink-Moenen (1989) illustrated adult antennal characters which readily serve to distinguish adults of this species from those of Tetralicia ericae on the same hosts. A note on the puparial variability of T. ericae was published by Iaccarino \& Viggiani (1988)

\section{Trialeurodes lauri (Signoret) \\ (fig. 69)}

Aleurodes lauri Signoret, 1882: CLVIII.

Trialeurodes lauri (Signoret); Russell, 1947: 6

Trialeurodes klemmi Takahashi, 1940: 148-149 [synonymized by Russell, 1947: 7].

Distribution. Europe and Mediterranean countries: France, Greece, Israel Italy, Malta, Sicily, Turkey, Yugoslavia. Elsewhere in Palaearctic Region: Federation of Independent States.

Host plants. Ericaceae; Arbutus andrachne; Lauraceae: Laurus nobilis.

Comments. This is a native Mediterranean species, and recent collecting indicates that it is likely to be quite widespread. It is possible that this species may prove to be a variant of $T$. ricini (Misra)

\section{Trialeurodes packardi (Morrill) (figs 70-73)}

Aleyrodes packardi Morrill, 1903: 25-35.

Trialeurodes packardi (Morrill) Quaintance \& Baker, 1915: xi.

Distribution. Europe and Mediterranean countries: Hungary. Nearctic Region: widely distributed in Canada and USA

Host plants. In Europe, T. packardi has only been found on strawberries (Fragaria vesca, Rosaceae). In its native Nearctic Region, it is polyphagous, with hosts in 26 dicotyledonous families listed by Mound \& Halsey (1978).

Comments. The presence of this species in Europe was recorded by Kozár et al. (1987) and by Kozár \& Bink-Moenen (1988), where it was reported to be a pest of strawberries (Fragaria vesca cultivated varieties). It was firs detected when colonies of Trialeurodes were observed to overwinter on strawberries in the open, whereas $T$. vaporariorum normally survives the rigours of the European continental winter in glasshouses. This species continues to affect strawberries in Hungary (F. Kozár, personal communication). It may be more widely distributed in Europe, remaining unrecognized because of its similarity to $T$. vaporariorum, which it closely resembles until examined microscopically (see key, couplet 12). 


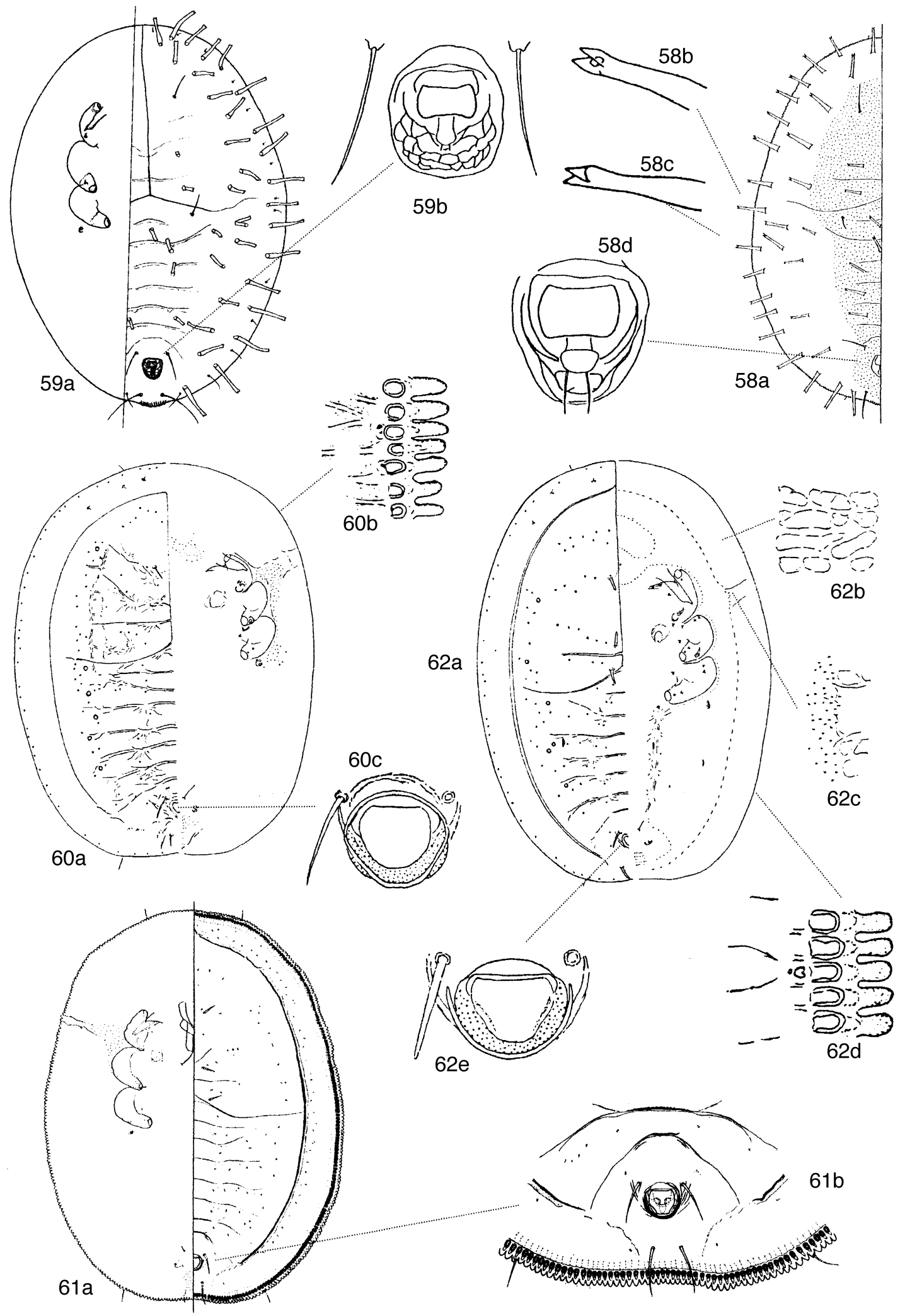

Figs 58-62. 58, Siphoninus immaculatus, puparium (from Mound, 1966); 59, Siphoninus phillyreae, puparium (adapted from Martin, 1987 and Mound, 1966); 60, Tetraleurodes bicolor, puparium (from Bink-Moenen \& Gerling, 1992); 61, Tetraleurodes hederae (from Rapisarda, 1982); 62, Tetraleurodes neemani, puparium (from Bink-Moenen \& Gerling, 1992). 

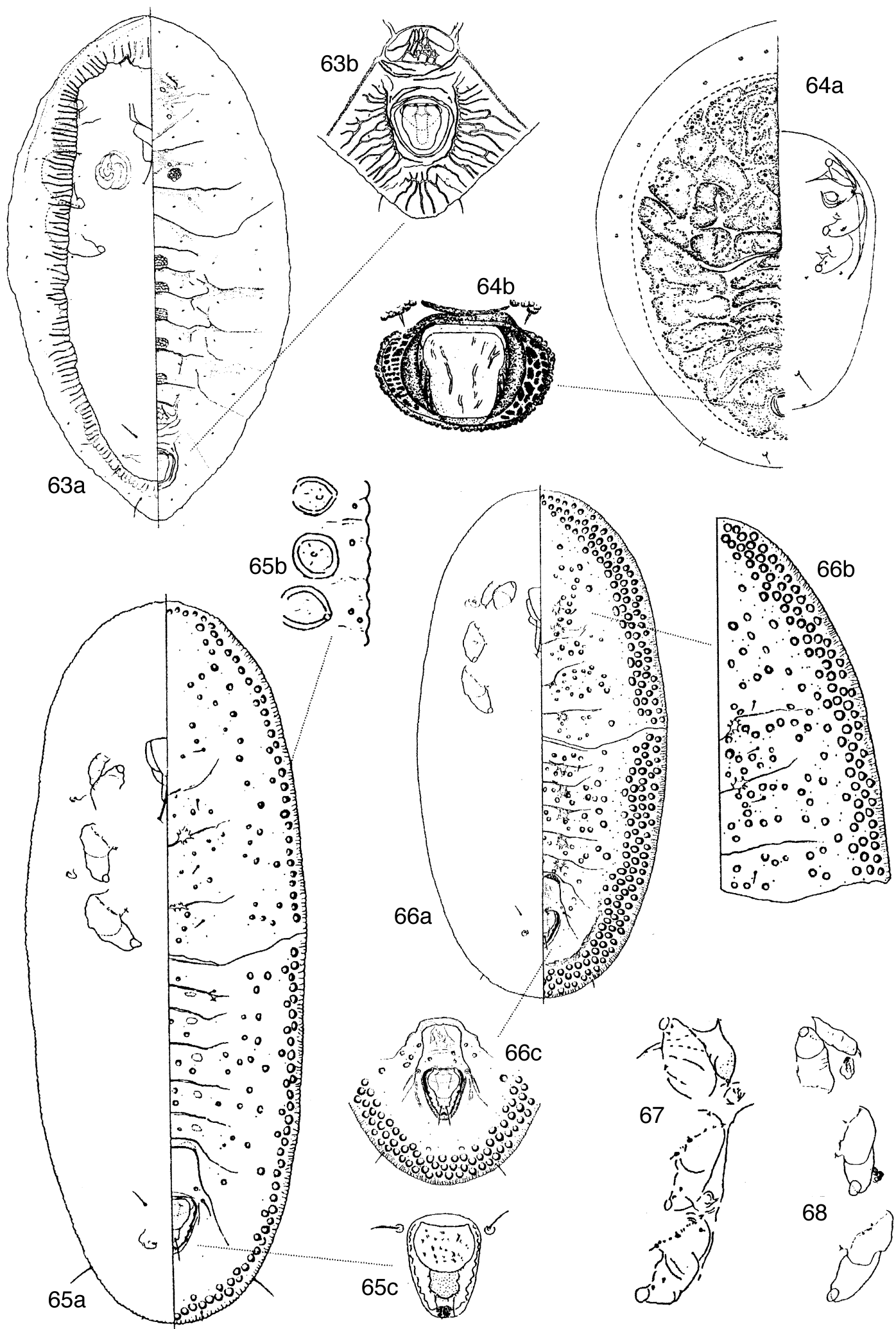

Figs 63-68. 63, Tetralicia ericae, puparium (from Rapisarda, 1982); 64, Tetralicia iberiaca, puparium (from Bink-Moenen, 1989); 65, Trialeurodes ericae, puparium (from Bink-Moenen, 1976); 66, Trialeurodes sardiniae, puparium (from Rapisarda, 1986); 67, Trialeurodes ericae, puparial legs (from Bink-Moenen, 1976); 68, Trialeurodes sardiniae, puparial legs (from Rapisarda, 1986). 

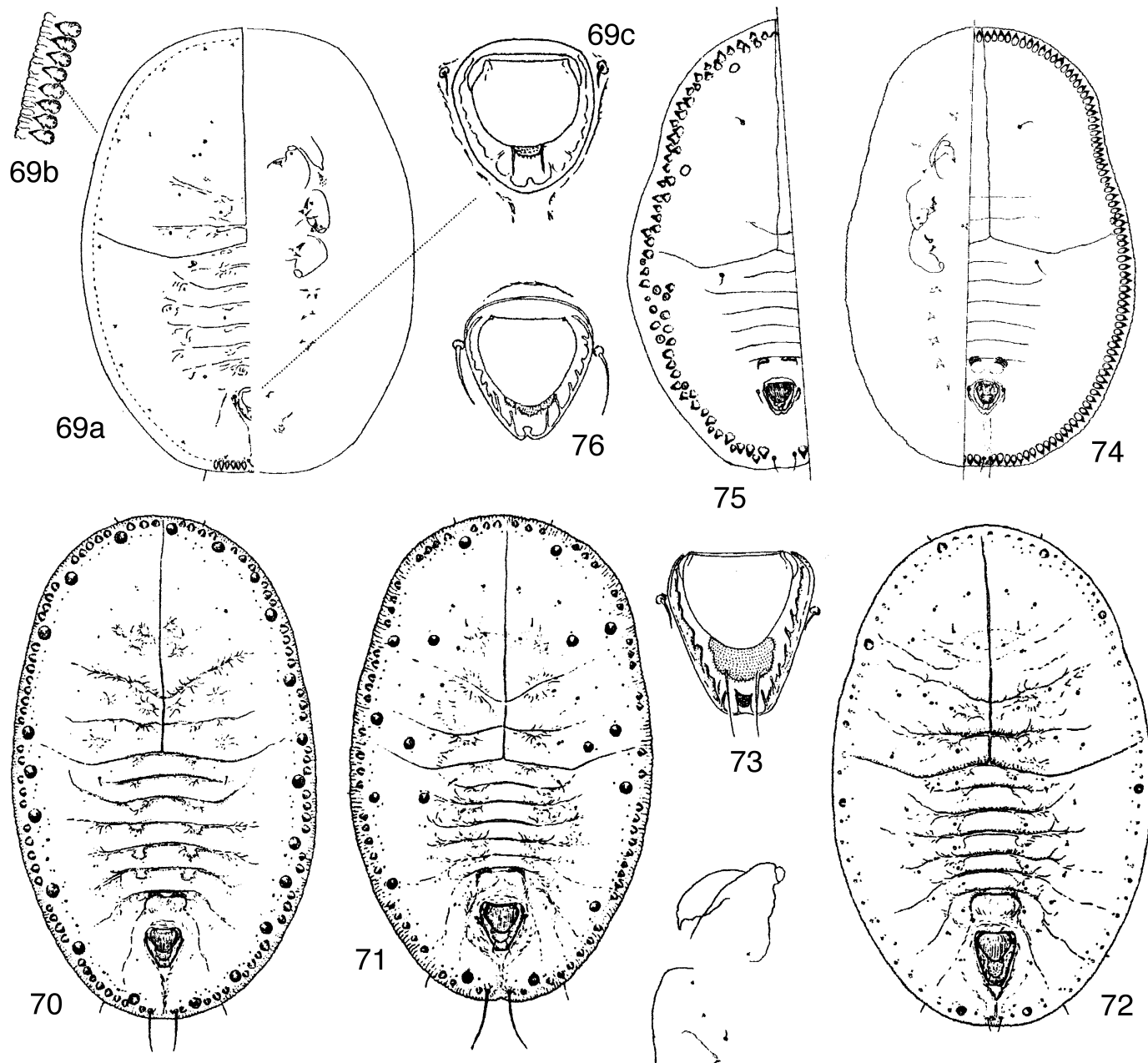

75
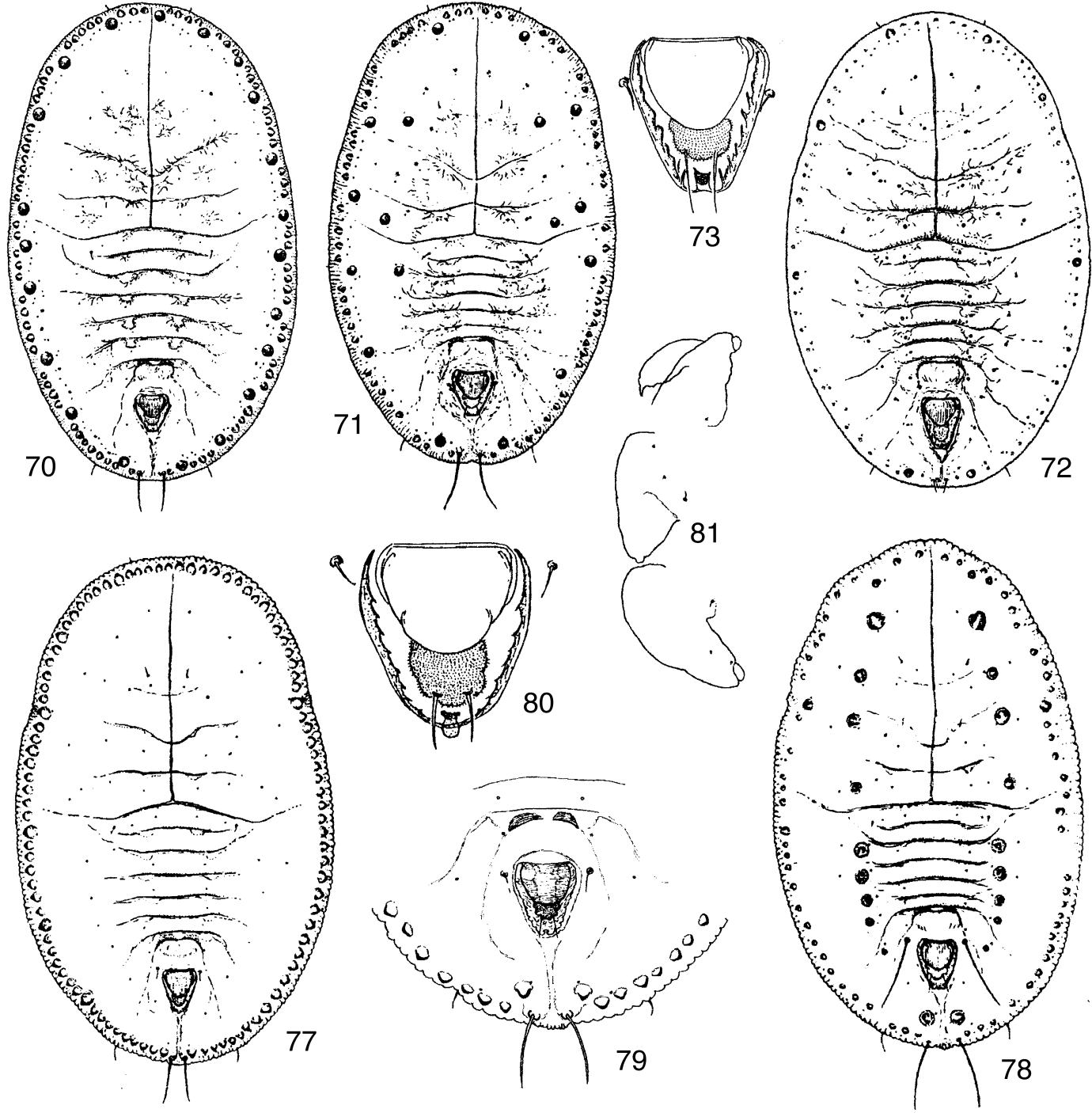

Figs 69-81. 69, Trialeurodes lauri, puparium (from Bink-Moenen \& Gerling, 1992); 70-72, Trialeurodes packardi, puparial variants (from Russell, 1948); 73, Trialeurodes packardi, vasiform orifice (from Kozár et al., 1987); 74-75, Trialeurodes ricini, puparia ex- (74) Securinega sp. and (75) Ricinus sp. (from Martin, 1987); 76, Trialeurodes ricini, vasiform orifice (from Kozár et al., 1987); 77-78, Trialeurodes vaporariorum, puparial variants (from Russell, 1948); 79, Trialeurodes vaporariorum, posterodorsal puparial detail (from Martin, 1987); 80, Trialeurodes vaporariorum, vasiform orifice (from Kozár et al., 1987); 81, Trialeurodes vaporariorum, puparial legs (from Martin, 1987). 


\section{Trialeurodes ricini (Misra)}

(figs 74-76)

Aleyrodes ricini Misra, 1924: 131-135.

Trialeurodes ricini (Misra) Singh, 1931: 46-47.

Distribution. Europe and Mediterranean countries: Egypt. Elsewhere in Palaearctic Region: Canary Islands, Iran, Iraq, Saudi Arabia. Ethiopian Region: Ivory Coast, Kenya, Malawi, Nigeria, Sierra Leone, Sudan, Uganda. Oriental Region: Hong Kong, India, Pakistan, Thailand. Austrooriental Region: Brunei, Philippines (Palawan).

Host plants. Hosts in eight angiosperm families were listed by Mound \& Halsey (1978): many others have been recorded subsequently, with 14 plant families being listed by Bink-Moenen (1983) from Chad alone. It is most often associated with castor oil plants (Ricinus communis, Euphorbiaceae). Comments. Although currently only recorded from Egypt in the area of study, this species is included in this account because its presence in Iran and Iraq indicates its likely occurrence in the countries bordering the eastern Mediterranean. Trialeurodes ricini may prove to be a senior synonym of $T$. lauri (above). Trialeurodes ricini occurs mainly across the Middle East, sub-Saharan Africa and in the Oriental Region.

\section{Trialeurodes sardiniae Rapisarda (figs 66, 68)}

Trialeurodes sardiniae Rapisarda, 1986: 493-497. Distribution. Europe and Mediterranean countries: Sardinia. Host plants. Ericaceae: Erica arborea.

Comments. This little-known species is still only represented in collections by the type specimens. The nature of Erica arborea leaves, which are very small and have their lateral margins curled downwards, contributes to this whitefly remaining obscure, because cryptic puparia are exceptionally difficult to see on such foliage.

\section{Trialeurodes vaporariorum (Westwood) (figs 77-81)}

Aleurodes vaporariorum Westwood, 1856: 852. Trialeurodes vaporariorum (Westwood) Quaintance \& Baker, 1915: xi.

Distribution. Europe and Mediterranean countries: throughout, although in northern countries it is found most readily in glasshouses. Elsewhere: cosmopolitan, although less common in tropical Asia.

Host plants. Extremely polyphagous being recorded from more than 200 plant genera, including many herbaceous and some monocotyledonous plants, and even a cycad, by Mound \& Halsey (1978). Many more hosts have been recorded since.

Comments. Trialeurodes vaporariorum, often called the glasshouse or greenhouse whitefly, is one of the two most common and economically important whitefly species (the other being Bemisia tabaci). With its long name often shortened to 'T. vap.' by whitefly workers, this species is often a considerable problem under glass, especially in more temperate areas. It is a member of a North American species-group (Russell, 1948), but was already a widespread pest at the time of its description (from England) in 1856, and was established in Australia by 1900 (Martin, 1999).

\section{Subfamily ALEURODICINAE Genus Aleurodicus Douglas}

Aleurodicus Douglas, in Morgan, 1892: 32. Type species Aleurodicus anonae Morgan, 1892: 32 [synonymized with $A$. cocois Curtis, 1846: 284-285 by Mound \& Halsey, 1978: 229].

\section{Aleurodicus dispersus Russell (fig. 82)}

Aleurodicus dispersus Russell, 1965: 49-54.

Distribution. Europe and Mediterranean countries: not yet recorded. Elsewhere in Palaearctic Region: Macaronesia. Ethiopian Region: Benin Congo, Ghana, Nigeria, Sao Tomé, Togo. Malagasian Region: Mauritius. Oriental Region: India, Maldives, Sri Lanka, Thailand. Austro-oriental, Pacific and Neotropical Regions: widely distributed. Australia: northern Queensland. Nearctic Region: USA (Florida).

Host plants. Extremely polyphagous, including herbaceous and monocotyledonous plants.

Comments. At the time of manuscript preparation, no member of the
Aleurodicus/Lecanoideus group is known to occur in mainland Europe or the Mediterranean seaboard countries. However, A. dispersus has been established in the Canary Islands since the 1960s, and has recently become established in Madeira and in west Africa. It is considered that there is a moderate risk of this species being introduced into the Mediterranean area in the future, although it was not listed for EU quarantine alert (Smith et al., 1997). Its current wide geographical distribution may be compared with its occurrence only in the neotropics, Florida and Canary Islands up to the mid-1970s, giving an indication of its potential to spread still further. Almost certainly, it will be climatic characteristics that determine its eventual distribution, regardless of quarantine vigilance.

\section{Genus Lecanoideus Quaintance \& Baker}

Aleurodicus (Lecanoideus) Quaintance \& Baker, 1913: 70. Type species Aleurodicus (Lecanoideus) giganteus Quaintance \& Baker, 1913: 70-71.

Lecanoideus Quaintance \& Baker, raised to genus by Costa Lima, 1928: 133

\section{Lecanoideus floccissimus Martin et al. (fig. 83)}

Lecanoideus floccissimus Martin et al., 1997: 1261-1272.

Distribution. Europe and Mediterranean countries: not yet recorded. Elsewhere in Palaearctic Region: Canary Islands (Gran Canaria, La Gomera, Tenerife). Neotropical Region: Colombia, Ecuador, [Trinidad].

Host plants. Polyphagous, with host records belonging to 30 plant genera collated by Hernández-Suárez et al. (1997).

Comments. Clearly an introduction from the Neotropics, this species was undescribed at the time of its establishment on Tenerife. In the Canary Islands, it currently causes extensive damage to banana plants, as well as to park and garden palms, trees, shrubs and ornamental monocots. It was actually recorded from more host plants in the Canary Islands, by Hernández-Suárez et al. (1997), than was Aleurodicus dispersus. Lecanoideus floccissimus may represent a considerable quarantine risk to the Mediterranean region, leading to its inclusion in this review.

\section{Genus Paraleyrodes Quaintance}

Paraleyrodes Quaintance, 1909: 169-170. Type species Aleurodes perseae Quaintance, 1900: 32-33.

\section{Paraleyrodes minei Iaccarino \\ (fig. 84)}

Paraleyrodes minei Iaccarino, 1990: 132-148.

Distribution. Europe and Mediterranean countries: Lebanon, Spain, Syria, Turkey. Ethiopian Region: Benin. Pacific Region: Hawaii. Neotropical Region: Belize, Guatemala, Mexico, Puerto Rico. Nearctic Region: Bermuda, USA (California, Florida, Texas)

Host plants. Apocynaceae: unidentified tree; Compositae: Lasianthaea fruticosa; Ericaceae: Rhododendron sp.; Lauraceae: Persea americana; Myrtaceae: Psidium guajava; Palmae: Cocos nucifera, Elaeis guineensis; Piperaceae: Piper sp.; Rubiaceae: Guettarda combesii; Rutaceae: Citrus spp.

Comments. Although described from citrus crops in Syria, this species is a native of the Neotropical Region, along with all species of Paraleyrodes and the great majority of the other members of the Aleurodicinae. Paraleyrodes minei is now often called the nesting whitefly, but this name should be used with caution, because it describes the wax-deposition habits of several members of this genus.

At the time of manuscript preparation, only P. minei is represented in mainland Europe and the Mediterranean area. However, several other species have recently become naturalized in countries beyond the New World tropics. Two of these other species, P. bondari Peracchi and P. citricolus Costa Lima are already established on Madeira, and their recognition is discussed by Martin (1996). A third species, undescribed, is now common in Hawaii, Hong Kong, Bermuda and Florida, clearly indicating the ease with which species of Paraleyrodes can become established.

\section{Species found only in glasshouses in the study area}

There are a few species of whiteflies which have been recorded, and some even described, from European glasshouses. They are not treated in the main part of this account, because there are no satisfactory records of their natural occurrence in the area of coverage. 


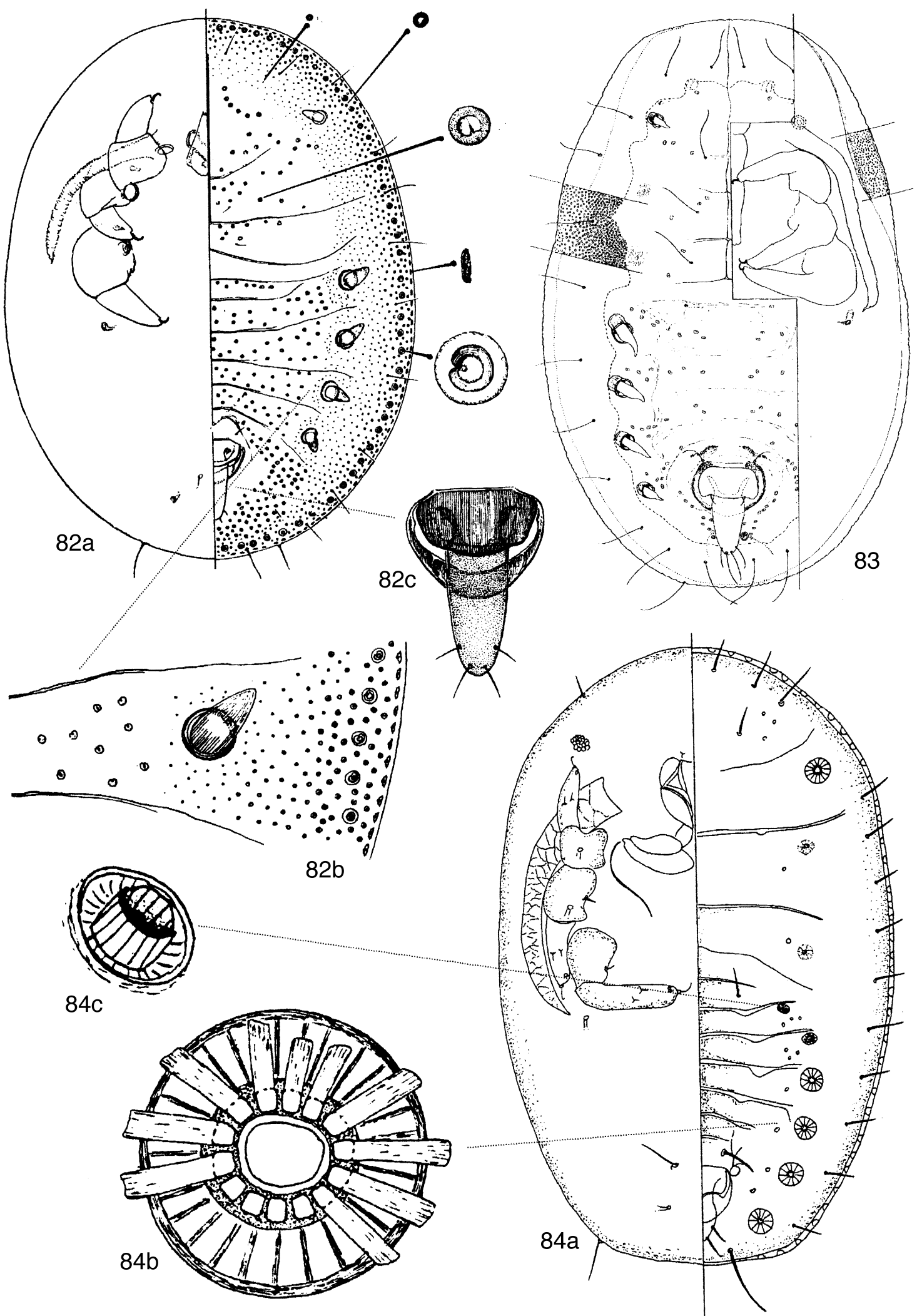

Figs 82-84. 82, Aleurodicus dispersus, puparium (from Russell, 1965); 83, Lecanoideus floccissimus, puparium (from Martin et al., 1997); 84, Paraleyrodes minei, puparium (from Iaccarino, 1990 and Martin, 1996). 


\section{Subfamily ALEYRODINAE}

\section{Aleuropteridis filicicola (Newstead)}

Aleyrodes filicicola Newstead, 1911: 174.

Aleuropteridis douglasi Mound, 1961: 128-129 [synonymized by Mound, 1965: 135].

Aleuropteridis filicicola (Newstead) Mound, 1965: 135.

Comments. This is a member of an African genus of fern-feeding whiteflies (Mound, 1961). As with Aleurotulus nephrolepidis (below), a population of A. filicicola from Kew Gardens (London, UK) was described as a new species, but was later synonymized.

\section{Aleurotulus nephrolepidis (Quaintance)}

Aleurodes nephrolepidis Quaintance, 1900: 29-30.

Aleurotulus nephrolepidis (Quaintance) Quaintance \& Baker, 1914: 102. Aleuroplatus kewensis Trehan, 1938: 183-186 [synonymized by Mound 1966: 410].

Comments. This species is a specialist fern-feeder, and is often found on ferns in artificially protected conditions. It is found in the open air in Macaronesia, but there are no similar records from the area covered by this work. Aleuroplatus kewensis was described as a new species, from Kew Gardens, but was later placed as a synonym of Aleurotulus nephrolepidis.

\section{Filicaleyrodes williamsi (Trehan)}

Trialeurodes williamsi Trehan, 1938: 186-189.

Filicaleyrodes williamsi (Trehan) Mound, 1966: 416.

Comments. There are published records of this species occurring in glasshouses in both England (from where it was described) and Hungary (Visnya, 1941b). Its geographical origin remains obscure.

\section{Subfamily ALEURODICINAE}

\section{Ceraleurodicus varus (Bondar)}

Radialeurodicus varus Bondar, 1928: 1-3.

Ceraleurodicus varus (Bondar) Costa Lima, 1928: 137.

Parudamoselis kesselyaki Visnya, 1941a: 5-12. Syn. n.

Ceraleurodicus kesselyaki (Visnya) Mound \& Halsey, 1978: 239.

Comments. This species, under the name Parudamoselis kesselyaki, was reported by Visnya (1941a), occurring in considerable numbers in an orchid house at Budapest Botanical Garden, Hungary. It had colonized several orchid species, and was present for several months in 1939-1940. Parudamoselis kesselyaki was clearly an introduction from the Neotropical Region, as tentatively posited by Visnya, but its synonymy with C. varus was only revealed when the first author of the present study was able to compare material of both nominal species, in the whitefly collection of the United States National Museum of Natural History (housed at the US Department of Agriculture, Beltsville, Maryland).

\section{Nomina dubia}

Three species, described from Europe, have descriptions which are inadequate or ambiguous to the point where recognition of the species is not possible from literature. Such a situation may be resolved if type material exists and can be examined by systematists in the future. With the present unavailability of authentic material for study, these taxa are here regarded as nomina dubia, even though they were listed as valid species by Mound \& Halsey (1978).

\section{Aleurodes capreae Signoret}

Aleurodes capreae Signoret, 1868: 384

Comments. Signoret (1868) stated of this species, found on Salix caprea, that the 'larval state' [puparium] 'greatly resembles those of the preceding species [plural]'. The preceding species in that account were Aleurodes rubi and $A$. fragariae, both now synonyms of Aleyrodes lonicerae. Also, Signoret continued by stating that the dorsal disc bore the same setae, in the same positions as in fragariae Walker. Given this data, and the polyphagy of $A$. lonicerae, it is possible that Aleurodes capreae is another synonym of lonicerae Walker. However, finding A. lonicerae colonizing tree hosts is unusual. Asterobemisia carpini is a more usual colonizer of trees, has been recorded from Salix, and its puparia sometimes develop stout dorsal setae in a similar configuration to those frequently seen adorning the puparia of Aleyrodes lonicerae. Nevertheless, there is insufficient descriptive data for this species to be recognized with certainty.

\section{Aleyrodes campanulae Saalas}

Aleyrodes campanulae Saalas, 1942a: 127-134.

Comments. Aleyrodes campanulae Salaas (1942a) answers the description of A. proletella in most respects. However, its puparia appear in drawings to be subjectively more elongate than is usual. Huldén (1986) provided a key to whiteflies in Finland, in which $A$. campanulae could only be distinguished by reference to its host plant and slightly elongate puparium. An attempt by the authors to locate material for study was unsuccessful. Aleyrodes campanulae may be a distinct species, but is considered more likely to be a variant of A. proletella or A. lonicerae, with its host preference indicating the latter to be more likely, despite the unusually short setae. With no study material currently available, it has not been possible to make a decision about the status of this species.

\section{Aleurodes fraxini Signoret}

Aleurodes fraxini Signoret, 1868: 386-387.

Comments. This species was described from adults alone, inhabiting leaves of 'frêne' (Fraxinus sp.). Although it is presumed that the taxa discussed by Signoret in his 1868 paper were from France unless otherwise stated, even this is not entirely certain. The description given by Signoret speaks of a blackish mark at the extremity of the main wing vein, indicating that this species was not Aleyrodes dubia Heeger (a junior synonym of Siphoninus phillyreae). Given the mobility of adult whiteflies, it is not possible to say whether Signoret's adults were even true Fraxinusfeeders. Neither is it possible to match with certainty these adults, as described, to known species.

\section{Acknowledgements}

We are grateful to a great many colleagues who have contributed data to this study. In particular, Rosita BinkMoenen (Netherlands) showed great generosity in contributing much information from her personal experience, and data from her collection of European whiteflies, along with invaluable critical comments on the manuscript. The reuse of illustrations which originally appeared in earlier publications, as credited, has saved much valuable preparation time. It is with particular pleasure that we record the willingness of Rosita Bink-Moenen, Jiri Zahradnik and the journal editors/publishers of Systematic Entomology, Acta Universitatis Carolinae, Biologica and Věstnik Československé Společnosti Zoologické to allow the re-use of previously published art work. We would like to thank the organizers and delegates of the first convening of the European Whitefly Studies Network (FAIR6 CT98-4303), for the exchange of ideas leading to our decision to embark on this account. A kind covenant by Mrs Pamela Salter greatly assisted in the purchase of sufficient reprints of this work to allow its distribution throughout the European Whitefly Studies Network and further afield. The first author would particularly like to express thanks to all those who have generously donated whitefly material to The Natural History Museum, London, the presence of such material being of great benefit in compiling and checking the key and distributional data. Nedim Uygun (Turkey) is thanked for having expedited the sending of several interesting Turkish samples at a late stage in manuscript preparation. 


\section{References}

Argov, Y. (1994) The woolly whitefly, a new pest in Israel [in Hebrew]. Alon Hanotea 48, 290-292.

Ashmead, W.H. (1885) The orange Aleurodes (Aleurodes citri n.sp.). Florida Dispatch 2, 704.

Ashmead, W.H. (1893) Monograph of the North American Procotrypidae. Amitus Haldemann. Bulletin of the United States National Museum 45, 292-294.

Baerensprung, F.V. (1849) Beobachtungen über einige einheimische Arten aus der Familie der Coccinen. pp. 165-176 in Alton, J.S.E d' (Ed.) Zeitung für Zoologie, Zootomie, und Palaeozoologie. Leipzig 1848-1849, 1-212.

Baker, A.C. \& Moles, M.L. (1920) A new species of Aleyrodidae found on Azalea (Hom.). Proceedings of the Entomological Society of Washington 22, 81-83.

Bedford, I.D., Briddon, R.W., Brown, J.K., Rosell, R.C. \& Markham, P.G. (1994) Geminivirus transmission and biological characterisation of Bemisia tabaci (Gennadius) biotypes from different geographic regions. Annals of Applied Biology 125, 311-325.

Bellows, T.S., Perring, T.M., Gill, R.J. \& Headrick, D.H. (1994) Description of a species of Bemisia (Homoptera: Aleyrodidae). Annals of the Entomological Society of America 87, 195-206.

Bemis, F.E. (1904) The aleyrodids or mealy-winged flies of California with reference to other American species. Proceedings of the United States National Museum 27, 471-537.

Bink, F. (1979) Methods for mounting Aleyrodidae specimens. Entomologische Berichten 39, 158-160.

Bink, F.A., Bink-Moenen, R.M. \& Woets, J. (1980) Witte vliegen in Nederland (Homoptera: Aleyrodidae). Entomologische Berichten 40, 3-9.

Bink-Moenen, R.M. (1976) A new whitefly of Erica tetralix: Trialeurodes ericae sp. n. (Homoptera, Aleyrodidae). Entomologische Berichten 36, 17-19.

Bink-Moenen, R.M. (1983) Revision of the African whiteflies (Aleyrodidae). Monografieën van de Nederlandse Entomologische Vereniging, Amsterdam 10, 1-211.

Bink-Moenen, R.M. (1989) A new species and new records of European whiteflies (Homoptera: Aleyrodidae) from heathers (Erica spp.). Entomologist's Gazette 40, 173-181.

Bink-Moenen, R.M. (1991) Comparisons between Neopealius rubi and Bemisia tabaci in Europe (Homoptera: Aleyrodidae). Entomologische Berichten 51, 29-37.

Bink-Moenen, R.M. (1992) Whitefly from Mediterranean evergreen oaks (Homoptera: Aleyrodidae). Systematic Entomology 17, 21-40.

Bink-Moenen, R.M. \& Gerling, D. (1992) Aleyrodidae of Israel. Bollettino di Laboratorio de Entomologia Agraria 'Filippo Silvestri' 47 1990, 3-49.

Bink-Moenen, R.M. \& Mound, L.A. (1990) Whiteflies: diversity, biosystematics and evolutionary patterns. pp. 1-11 in Gerling, D. (Ed.) Whiteflies, their bionomics, pest status and management. Andover, Intercept.

Blackman, R.L. \& Eastop, V.F.. (1994) Aphids on the world's trees an identification and information guide. $987 \mathrm{pp}$. Wallingford, CAB International.

Bondar, G. (1928) Aleyrodideos do Brasil. (2a contribuiçao). Boletim do Laboratorio de Pathologia Vegetal do Estado da Bahia $5,1-37$.

Brown, P.A. (1997) A review of techniques used in the preparation, curation and conservation of microscope slides at The Natural History Museum, London. The Biology Curator 10 (Supplement), 33 pp.
Brummit, R.K. (1992) Vascular plant families and genera. 804 pp. Royal Botanic Gardens, Kew.

Campbell, B.C., Steffen-Campbell, J.D. \& Gill, R.J. (1994) Evolutionary origin of whiteflies (Hemiptera: Sternorrhyncha: Aleyrodidae) inferred from $18 \mathrm{~S}$ rDNA esquences. Insect Molecular Biology 3, 73-88.

Campbell, B.C., Steffen-Campbell, J.D. \& Gill, R.J. (1996) Origin and radiation of whiteflies: an initial molecular phylogenetic assessment. pp. 29-51 in Gerling, D. \& Mayer, R.T. (Eds) Bemisia: 1995 - taxonomy, biology, damage, control and management. $702 \mathrm{pp}$. Andover, Intercept.

Carver, M. \& Reid, I.A. (1996) Aleyrodidae (Hemiptera: Sternorrhyncha) of Australia. Systematic catalogue, hostplant spectra, distribution, natural enemies and biological control. Technical Paper, Division of Entomology, Commonwealth Scientific and Industrial Research Organisation, Canberra 37, 55 pp.

Cock, M.J.W. (Ed.) (1986) Bemisia tabaci - a literature survey on the cotton whitefly with an annotated bibliography. $121 \mathrm{pp}$. CAB International Institute of Biological Control, Ascot.

Cock, M.J.W. (1993) Bemisia tabaci - an update 1986-1992. 78 pp. CAB International Institute of Biological Control, Ascot.

Cockerell, T.D.A. (1902) The classification of the Aleyrodidae. Proceedings on the Academy of Natural Sciences of Philadelphia 54, 279-283.

Corbett, G.H. (1936) New Aleurodidae (Hem.). Proceedings of the Royal Entomological Society of London (B) 5, 18-22.

Costa Lima, A. Da (1928) Contribuiçao as estudio dos aleyrodideos da subfamilia Aleurodicinae. Supplemento as Memorias. Instituto Oswaldo Cruz. Rio de Janeiro 4, 128-140.

Costa Lima, A. Da (1942) Sôbre Aleirodideos do gênero 'Aleurothrixus' (Homoptera). Revista Brasileira de Biologia 2(4), 419-426.

Curtis, J. (as 'Ruricola') (1846) Aleyrodes cocois (the cocoa-nut Aleyrodes). Gardener's Chronicle 1846, 284-285.

Danzig, E.M. (1964) The whiteflies (Homoptera, Aleyrodoidea) of the Caucasus. Entomologicheskoe Obozrenie 43, 633-646. [English translation in Entomological Review. Washington 43, 325-330.]

Danzig, E.M. (1966) The whiteflies (Homoptera, Aleyrodoidea) of the southern Primor'ye (Soviet Far East). Entomologicheskoe Obozrenie 45, 364-386. [English translation in Entomological Review. Washington 45, 197-209.]

Danzig, E.M. (1969) On the fauna of the whiteflies (Homoptera, Aleyrodoidea) of Soviet Central Asia and Kazakhstan. Entomologicheskoe Obozrenie 48, 868-880. [English translation in Entomological Review. Washington 48, 552-559.]

Danzig, E.M. (1980) The nomenclature and synonymy of several species of Coccinea and Aleyrodinea (Homoptera). Entomologicheskoe Obozrenie 59, 594-596. [English translation in Entomological Review. Washington 59, 73-74].

De Barro, P.J., Liebregts, W. \& Carver, M. (1998) Distribution and identity of biotypes of Bemisia tabaci (Gennadius) (Hemiptera: Aleyrodidae) in member countries of the Secretariat of the Pacific Community. Australian Journal of Entomology 37, 214-218.

De Barro, P.J., Driver, F., Trueman, J.W.H. \& Curran, J. (2000) Phylogenetic relationship of world populations of Bemisia tabaci (Gennadius) using ribosomal ITS1. Molecular Phylogeny and Evolution 15 (in press).

Del Bene, G., Gargani, E. \& Landi, S. (1991) Note su Pealius azaleae (Baker et Moles) (Hom. Aleyrodidae) specie nuova per l'Italia. Redia 74, 163-175. 
Dobreanu, E. \& Manolache, C. (1969) Homoptera Aleyrodoidea, Subfamilia Aleyrodinae. Fauna Republicii Socialiste România. Insecta 8, 1-152.

Dolling, W.R. \& Martin, J.H. (1985) Aleurochiton acerinus Haupt, a maple-feeding whitefly new to Britain. Entomologist's Monthly Magazine 121, 143-144.

Fowler, V.W . (1954) Notes on some pests observed in the course of advisory work at Wisley during 1953. Journal of the Royal Horticultural Society 79, 405-408.

Frauenfeld, G.R. (1867) Zoologische Miscellen XIII. Ueber Aleurodes und Thrips, vorzüglich im Warmhause. Verhandlungen der Zoologische-Botanischen Gesellschaft in Wien 17, 793-800.

Frohlich, D.R., Torres-Jerez, I., Bedford, I.D., Markham, P.G. \& Brown, J.K. (1999) A phylogeographical analysis of the Bemisia tabaci species complex based on mitochondrial DNA markers. Molecular Ecology 8, 1683-1691.

Gennadius, P. (1889) [Disease of tobacco plantations in the Trikonia. The aleurodid of tobacco.] [In Greek.] Ellenike Georgia 5, 1-3.

Geoffroy, E.L. (1762) Histoire abrégée des insectes qui se trouvent aux environs de Paris. I. 523 pp. Paris.

Gertsson, C.A. (1987) Den svenska mjöllusfaunan. Entomologisk Tidskrift 108, 85-91.

Gill, R.J. (1990) The morphology of whiteflies. pp. 13-46 in Gerling, D. (Ed.) Whiteflies, their bionomics, pest status and management. $348 \mathrm{pp}$. Andover, Intercept.

Gomez-Menor, J. (1945) Contribución al conocimiento de los aleyródideos de España (Hem. Homoptera). Variabilidad en las especies españolos y descripción de dos nuevas. $2^{\text {a }}$ nota. Eos, Madrid 20, 277-308.

Gomez-Menor, J. (1953) Algunos insectos como pequeños enemigos: los Aleurodidos. Revista de la Universidad de Madrid 2, 27-55.

Gomez-Menor, J. (1958) Entomologia forestal. Homopteros Sternorrhyncha que atacan a la encina. Familia Aleyrodidae. Graellsia 16, 125-139.

Goux, L. (1939) Contribution à l'étude des aleurodes (Hem. Aleyrodidae) de la France I. Description d'un sous-genre et deux espèces nouveaux. Bulletin de la Société Linnéenne de Provence 12, 77-82.

Goux, L. (1940) Contribution à l'étude des aleurodes (Hem. Aleyrodidae) de la France II. Description de deux espèces nouvelles de Marseille. Bulletin de la Société Entomologique de France 45, 45-48.

Goux, L. (1942) Contribution à l'étude des aleurodes (Hem. Aleyrodidae) de la France III. Description d'un Aleurolobus et d'un Aleurotrachelus nouveaux. Bulletin du Muséum d'Histoire Naturelle de Marseille 2, 141-148.

Goux, L. (1945) Contribution à l'étude des aleurodes (Hem. Aleyrodidae) de la France IV. Étude morphologique et biologique d'une espèce nouvelle constituant un genre nouveau. Bulletin du Muséum d'Histoire Naturelle de Marseille 5, 186-197.

Goux, L. (1988) Aleurodes de France - VII. Description de deux espèces nouvelles constituant des genres nouveaux. Bulletin de la Société Linnéenne de Provence 39, 63-66.

Greathead, A.H. (1986) Host plants. pp. 17-25 in Cock, M.J.W. (Ed.). Bemisia tabaci - a literature survey on the cotton whitefly with an annotated bibliography. $121 \mathrm{pp}$. CAB International Institute of Biological Control, Ascot.

Guirao, P., Beitia, F. \& Cenis, J.L. (1997) Biotype determination of Spanish populations of Bemisia tabaci (Hemiptera: Aleyrodidae). Bulletin of Entomological Research 87, 587-593.
Habib, A. \& Farag, F.A. (1970) Studies on nine common aleurodids of Egypt. Bulletin de la Société Entomologique d'Egypte 54, 1-41.

Haliday, A.H. (1835) Aleyrodes phillyreae. Entomological Magazine 2, 119-120.

Harrison, J.W.H. (1917) A new species and genus of Aleyrodidae from Durham. The Vasculum 3, 60-62.

Harrison, J.W.H. (1931) Some observations on Aleurodidae. Entomologist's Record and Journal of Variation 43, 84-86.

Haupt, H. (1934) Neues über die Homoptera - Aleurodina. Deutsche Entomologische Zeitschrift. Berlin 1934, 127-141.

Haupt, H. (1935) Schmetterlings - od. Mottenläuse, Aleurodina. in Die Tierwelt Mitteleuropas 4, 253-260.

Heeger, E. (1856) Beiträge zur Naturgeschichte der Insecten Naturgeschichte der Aleurodes immaculata Steph. Sitzungberichte der Kaiserlichen Akademie der Wissenschaften. Mathematische-naturwissenschaftliche klasse. Wien 18, 33-36.

Hernández-Suárez, E., Carnero, A., Hernández, M., Beitia, F. \& Alonso, C. (1997) Lecanoideus floccissimus (Homoptera, Aleyrodidae): nueva plaga en las Islas Canarias. Phytoma España 91, 35-48.

Hodgson, C.J. (1994) The scale insect family Coccidae: an identification manual to genera. $639 \mathrm{pp}$. Wallingford, CAB International.

Huldén, L. (1986) The whiteflies (Homoptera, Aleyrodoidea) and their parasites in Finland. Notulae Entomologicae 66, $1-40$.

Iaccarino, F.M. (1981) Aleirodidi nuovi o poco noti per l'Italia. Bollettino del Laboratorio di Entomologia Agraria 'Filippo Silvestri' 38, 143-156.

Iaccarino, F.M. (1982) Descrizione di Aleuroviggianus adrianae, $\mathrm{n}$. gen, n. sp. (Homoptera: Aleyrodidae). Bollettino del Laboratorio di Entomologia Agraria 'Filippo Silvestri' 39, 37-45.

Iaccarino, F.M. (1985) Nuovi generi e specie di Aleirodidi per la fauna italiana. Bollettino del Laboratorio di Entomologia Agraria 'Filippo Silvestri' 42, 135-141.

Iaccarino, F.M. (1990) Descrizione di Paraleyrodes minei n. sp. (Homoptera: Aleyrodidae), nuovo aleirodide degli agrumi, in Siria. Bollettino del Laboratorio di Entomologia Agraria 'Filippo Silvestri' 46, 131-149.

Iaccarino, F.M. \& Viggiani, G. (1988) Nuovi reperti su Aleirodidi italiani e loro parassitoidi. Atti XV Congresso Nazionale Italiano di Entomologia, 917-923.

Jensen, A. (1999) Cladistics of a sampling of the world's diversity of whiteflies of the genus Dialeurodes (Hemiptera: Aleyrodidae). Annals of the Entomological Society of America 92, 359-369.

Jensen, A. (in press) A cladistic analysis of Dialeurodes Massilieurodes and Singhiella (Hemiptera: Aleyrodidae), with notes and keys to the Nearctic species and descriptions of four new Massilieurodes species. Systematic Entomology.

Jesudasan, R.W.A. \& David, B.V. (1991) Taxonomic studies on Indian Aleyrodidae (Insecta: Homoptera). Oriental Insects $25,231-434$.

Kirkaldy, G.W. (1907) A catalogue of the family Aleyrodidae. Bulletin. Board of Commisioners of Agriculture and Forestry, Hawaii, Division of Entomology 2, 1-92.

Klasa, A. (1987) Maczliki (Homoptera, Aleyrodoidea) wylotu Bramy Morawskiej. Acta Biologica Silesiana 6, 119-126.

Klimaszewski, S. \& Szelegiewicz, H. (1962) Materialen zur Kenntnis der Mottenläuse (Homoptera, Aleyrodidae) Polens. Fragmenta Faunistica 10, 35-45.

Koch, C.L. (1857) Die Pflanzenläuse Aphiden. 330 pp. Nürnberg.

Korobitsin, V.G. (1967) New and little-known species of 
aleyrodids (Homoptera, Aleyrodoidea) from Crimea. Entomologicheskoe Obozrenie 46, 857-859. [English translation in Entomological Review. Washington 46, 510-512.]

Kotinsky, J. (1907) Aleyrodidae of Hawaii and Fiji with descriptions of new species. Bulletin. Board of Commisioners of Agriculture and Forestry, Hawaii, Division of Entomology 2, 93-102.

Kozár, F. \& Bink-Moenen, R.M. (1988) New data to the knowledge of the whiteflies of the Palaearctic Region (Homoptera: Aleyrodidae). Folia Entomologica Hungarica 49, 117-121.

Kozár, F., Bink-Moenen, R.M., Darvas, B. \& Urfiné-Fogarasi, E. (1987) Új kártevö, a szamóca-molytetü (Trialeurodes packardi Morrill; Homoptera: Aleyrodidae) megjelenése Magyarországon. Növényvédelem 23, 351-354.

Kuwana, I. (1911) The whiteflies of Japan. Pomona College Journal of Entomology 3, 620-627.

Kuwana, I. (1927) On the genus Bemisia (Family Aleyrodidae) found in Japan, with description of a new species. Annotaciones Zoologicae Japonenses 11, 245-251.

Laing, F. (1928) Description of a white fly pest of rhododendrons. Entomologist's Monthly Magazine 64, 228-230.

Latreille, P.A. (1795) Magazin Encyclopédique 4, 304-310.

Latreille, P.A. (1796) Précis des charactères génériques des Insectes, disposés dans un ordre naturel. Paris.

Latreille, P.A. (1801-02) Histoire naturelle des crustacés et des insectes. 3, 468 pp. Paris.

Lindinger, L. (1932) Randbermerkungen. Entomologische Rundschau. Stuttgart 1932, 222-223.

Linnaeus, C. (1758) Systema Naturae. 824 pp. Uppsala.

Llorens-Climent, J.M. \& Garrido Vivas, A. (1992) Homóptera III. Moscas blancas y sus control biológico. 203 pp. Alicante, Pisa Ediciones.

Longo, S., Rapisarda, C., Russo, A. \& Siscaro, G. (1990) Relievi bio-ethologici preliminari su Parabemisia myricae (Kuwana) e sui suoi entomofagi in Sicilia e Calabria. Bollettino di Zoologia Agraria e di Bachicoltura (II) 22, 161-171.

Löw, F. (1867) Zoologische Notizen Zweite Serie. Verhandlungen der Zoologische-Botanischen Gesellschaft in Wien 17, 745-752.

Martin, J.H. (1978) Aleurochiton complanatus (Baerensprung) (Aleyrodidae) - confirmation of occurrence in Britain. Entomologist's Monthly Magazine 113, 7.

Martin, J.H. (1987) An identification guide to common whitefly pest species of the world (Homoptera, Aleyrodidae). Tropical Pest Management 33, 298-322.

Martin, J.H. (1996) Neotropical whiteflies of the subfamily Aleurodicinae established in the western Palaearctic (Homoptera: Aleyrodidae). Journal of Natural History 30, 1849-1859.

Martin, J.H. (1999) The whitefly fauna of Australia (Sternorrhyncha: Aleyrodidae), a taxonomic account and identification guide. Technical Paper, CSIRO Entomology 38, $1-197$.

Martin, J.H. \& Hollis, D. (1992) The Calophyllum-feeding triozid genus Leptynoptera (Hemiptera: Psylloidea). Journal of Natural History 26, 555-585.

Martin, J.H., Aguiar, A.M.F. \& Pita, M.T. (1996) Aleyrodidae of Madeira - descriptions of three new species and notes on a pan-Mediterranean species of Aleurotrachelus. Journal of Natural History 30, 113-125.

Martin, J.H., Hernández-Suárez, E. \& Carnero, A. (1997) An introduced new species of Lecanoideus (Homoptera:
Aleyrodidae) established and causing economic impact on the Canary Islands. Journal of Natural History 31, 1261-1272.

Maskell, W.M. (1896) Contributions towards a monograph of the Aleurodidae, a family of Hemiptera - Homoptera. Transactions of the New Zealand Institute 28, 411-449.

Mifsud, D. (1995) Whiteflies of the Maltese Islands (Homoptera, Aleyrodidae). Central Mediterranean Naturalist 2, 61-78.

Mifsud, D. \& Palmeri, V. (1996) A new species of Aleurolobus Quaintance \& Baker (Homoptera, Aleyrodidae) from southern Europe. Bollettino del Laboratorio di Entomologia Agraria 'Filippo Silvestri' 52, 89-95.

Misra, C.S. (1924) The citrus whitefly, Dialeurodes citri in India and its parasite, together with the life history of Aleurodes ricini, n.sp. Report of Proceedings of Entomological Meetings at Pusa 1923, 129-135.

Modeer, A. (1778) Om fastflyet Coccus. Götteborgs Kungl. Vetenskaps och Vitterhets Samhälles Handlingar. Ny Tidsföljd 1, 11-50.

Morgan, A.C.F. (1892) A new genus and species of Aleurodidae. Entomologist's Monthly Magazine 28, 29-33.

Morrill, A.W. (1903) Life history and description of the strawberry Aleyrodes, A. packardi n. sp. Canadian Entomologist 35, 25-35.

Mound, L.A. (1961) A new genus and four new species of whitefly from ferns (Homoptera, Aleyrodidae). Revue de Zoologie et de Botanique Africaines 64, 127-132.

Mound, L.A. (1963) Host-correlated variation in Bemisia tabaci (Gennadius) (Homoptera: Aleyrodidae). Proceedings of the Royal Entomological Society of London (A)38, 171-180.

Mound, L.A. (1965) An introduction to the Aleyrodidae of western Africa (Homoptera). Bulletin of the British Museum (Natural History) (Entomology) 17, 113-160.

Mound, L.A. (1966) A revision of the British Aleyrodidae (Hemiptera: Homoptera). Bulletin of the British Museum (Natural History) (Entomology) 17, 399-428.

Mound, L.A. \& Halsey, S.H. (1978) Whitefly of the World. 340 pp. British Museum (Natural History)/John Wiley \& Sons, Chichester.

Mound, L.A., Martin, J.H. \& Polaszek, A. (1994) The insect fauna of Selaginella (Pteridophyta: Lycopsida), with descriptions of three new species. Journal of Natural History 28, 1403-1415.

Newstead, R. (1911) On a collection of Coccidae and Aleurodidae, chiefly African, in the collection of the Berlin Zoological Museum. Mitteilungen aus dem Zoologischen Museum in Berlin 5, 153-174.

Ossiannilsson, F. (1947) Bemisia callunae n. sp., a new Swedish white fly (Hom. Aleurodidae). Entomologisk Tidskrift 68, 1-3.

Ossiannilsson, F. (1955) Till kännedomen om de svenska mjöllössen (Hem. Hom. Aleyrodina). Opuscula Entomologica 20, 192-199.

Passos de Carvalho, J. (1994) A mosquinha-branca-dos-citrinos Aleurothrixus floccosus (Maskell, 1895) (Homoptera Aleyrodidae). 109 pp. Direcção Regional de Agricultura da Região Autónoma da Madeira, Instituto Nacional de Investigação Agrária, Funchal.

Patti, I. \& Rapisarda, C. (1981) Reperti morpho-biologici sugli Aleirodidi nocivi alle piante coltivate in Italia. Bollettino di Zoologia Agraria e di Bachicoltura (II) 16, 135-190.

Pizza, M. \& Porcelli, F. (1993) Sull'allestimento di preparati microscopici di pupari di Aleirodidi (Homoptera). Bollettino della Società Entomologica Italiana 125, 3-5.

Polunin, O. \& Walters, M. (1985) A guide to the vegetation of Britain and Europe. 238 pp. Oxford, Oxford University Press.

Priesner, H. \& Hosny, M. (1932) Contributions to a knowledge of the whiteflies (Aleurodidae) of Egypt (I). Bulletin. 
Ministry of Agriculture, Egypt. Technical and Scientific Service 121, 1-8.

Priesner, H. \& Hosny, M. (1934a) Contributions to a knowledge of the whiteflies (Aleurodidae) of Egypt (II). Bulletin. Ministry of Agriculture, Egypt. Technical and Scientific Service 139, 1-21.

Priesner, H. \& Hosny, M. (1934b) Contribution to a knowledge of the whiteflies (Aleurodidae) of Egypt (III). Bulletin. Ministry of Agriculture, Egypt. Technical and Scientific Service 145, 1-11.

Quaintance, A.L. (1900) Contribution towards a monograph of the American Aleurodidae. Technical Series, US Department of Agriculture Bureau of Entomology 8, 9-64.

Quaintance, A.L. (1903) New Oriental Aleurodidae. Canadian Entomologist 35, 61-64.

Quaintance, A.L. (1907) The more important Aleurodidae infesting economic plants with description of new species infesting the orange. Technical Series, US Department of Agriculture Bureau of Entomology 12, 89-94.

Quaintance, A.L. (1909) A new genus of Aleyrodidae, with remarks on Aleyrodes nubifera Berger and Aleyrodes citri Riley \& Howard. Technical Series, US Department of Agriculture Bureau of Entomology 12, 169-174.

Quaintance, A.L. \& Baker, A.C. (1913) Classification of the Aleyrodidae Part I. Technical Series, US Department of Agriculture Bureau of Entomology 27, 1-93.

Quaintance, A.L. \& Baker, A.C. (1914) Classification of the Aleyrodidae Part II. Technical Series, US Department of Agriculture Bureau of Entomology 27, 95-109.

Quaintance, A.L. \& Baker, A.C. (1915) Classification of the Aleyrodidae - contents and index. Technical Series, US Department of Agriculture Bureau of Entomology 27, i-xi, 111-114.

Quaintance, A.L. \& Baker, A.C. (1916) Aleyrodidae, or white flies attacking the orange, with descriptions of three new species of economic importance. Journal of Agricultural Research 6, 459-472.

Quaintance, A.L. \& Baker, A.C. (1917) A contribution to our knowledge of the whiteflies of the sub-family Aleurodinae (Aleyrodidae). Proceedings of the United States National Museum 51, 335-445.

Rapisarda, C. (1982) Appunti morfologici ed ecologici su alcuni aleirodi (Homoptera, Aleyrodidae) della fauna siciliana. Bollettino del Laboratorio di Entomologia Agraria 'Filippo Silvestri' 39, 71-95.

Rapisarda, C. (1985) Presenza in Italia di Aleurolobus niloticus Priesner \& Hosny, nuovo parassita delle piante di cappero (Homoptera, Aleyrodidae). Bollettino di Zoologia Agraria e di Bachicoltura (II) 18, 75-86.

Rapisarda, C. (1986) Trialeurodes (Ericaleyrodes) sardiniae, subgen. n., sp. n., a new heather-feeding whitefly (Homoptera Aleyrodidae). Frustula Entomologica (N.S.) 7-8, 487-499.

Rapisarda, C. (1990) Gli aleirodi degli agrumi in Italia Phytophaga 3, 173-198.

Rapisarda, C. (1995) Aleyrodoidea [pp. 2, 4-5, 12-13, 52]. In Barbagallo, S. et al., Homoptera Sternorrhyncha, vol. 43, in Minelli, A., Ruffo, S. \& La Posta, S. (Eds) Checklist delle specie della fauna italiana. vi +57 pp. Calderini, Bologna.

Rapisarda, C. (1999) Annotazioni faunistiche ed ecologiche sugli aleirodi italiani. Atti dell'Accademia Nazionale Italiana di Entomologia, Rendiconti 45, 195-221.

Rapisarda, C. \& Patti, I. (1983) Stato attuale delle conoscenze sulla composizione dell' aleirofauna siciliana. Atti XIII Congresso Nazionale Italiano di Entomologia, 327-332.

Rapisarda, C., Siscaro, G., Leocata, S. \& Asero, C. (1990)
Parabemisia myricae, un nuovo aleirode degli agrumi in Italia. Informatore Fitopatologico 40, 25-30.

Rapisarda, C., Mifsud, D. \& Martin, J.H. (1996) Current studies on the whitefly fauna of the Mediterranean basin (Homoptera, Aleyrodidae). Proceedings of the XX International Congress of Entomology, 92, abstract 02-090.

Riley, C.V. \& Howard, L.O. (1893) The orange Aleyrodes. (Aleyrodes citri n.sp.). Insect Life. US Department of Agriculture, Washington DC 5, 219-226.

Rosell, R.C., Bedford, I.D., Frohlich, D.R., Gill, R.J., Brown J.K. \& Markham, P.G. (1997) Analysis of morphological variation in distinct populations of Bemisia tabaci (Homoptera: Aleyrodidae). Annals of the Entomological Society of America 90, 575-589.

Russell, L.M. (1947) A classification of the whiteflies of the new Tribe Trialeurodini (Homoptera: Aleyrodidae). Revista de Entomologia. Rio de Janeiro 18, 1-44.

Russell, L.M. (1948) The North American species of whiteflies of the genus Trialeurodes. Miscellaneous Publications.United States Department of Agriculture 635, 1-85.

Russell, L.M. (1957) Synonyms of Bemisia tabaci (Gennadius) (Homoptera: Aleyrodidae). Bulletin of the Brooklyn Entomological Society 52, 122-123.

Russell, L.M. (1960) A whitefly living on roses (Homoptera: Aleyrodidae). Proceedings of the Royal Entomological Society of London (B) 29, 29-32.

Russell, L.M. (1962) New name combinations and and notes on some African and Asian species of Aleyrodidae (Homoptera). Bulletin of the Brooklyn Entomological Society 57, 63-65.

Russell, L.M. (1964) Dialeurodes kirkaldyi (Kotinsky), a whitefly new to the United States (Homoptera: Aleyrodidae). Florida Entomologist 47, 1-4.

Russell, L.M. (1965) A new species of Aleurodicus Douglas and two close relatives (Homoptera: Aleyrodidae). Florida Entomologist 48, 47-55.

Ryberg, O. (1938) Bidrag till kännedomen om de nordiska mjöllössen, Aleurodidae (Hem. Hom.) jämte provisorisk katalog över de europeiska arternas värdväxter. Kungl. Fysiografiska Sällskapets I Lund Förhandlingar 8, 10-25.

Salaas, U. (1942a) Eine neue Mottenlaus, Aleurodes campanulae n. sp. (Hem. Aleurodidae) an Campanula. Suomen Hyönteistieteellinen Aikakauskirja 8, 127-134.

Salaas, U. (1942b) Aleurodes proletella L. (Hem. Aleurodidae) jauhiainen tavattu Suomessa. Suomen Hyönteistieteellinen Aikakauskirja 8, 181-182.

Sampson, W.W. (1943) A generic synopsis of the hemipterous superfamily Aleyrodoidea. Entomologica Americana (N.S.) 23, 173-223.

Schlee, D. (1970) Verwandtschaftsforschung an fossilen und rezenten Aleyrodina (Insecta, Hemiptera). Stuttgarter Beiträge zur Naturkunde aus dem Staatlichen Museum für Naturkunde in Stuttgart 213, 1-72.

Schrank, F. von P. (1801) Fauna Boica 2. 274 pp. Ingolstadt.

Schumacher, F. (1918) Mottenläuse. Verzeichnis der Aleyrodiden Europas. Deutsche Entomologische Zeitschrift. Berlin 1918, 404-406.

Signoret, V. (1868) Essai monographique sur les aleurodes. Annales de la Société Entomologique de France 8, 369-402.

Signoret, V. (1882) Séance du 14 décembre 1881. $4^{\circ}$ Note. Annales de la Société Entomologique de France 1, CLVIII.

Silvestri, F. (1911) Di una nuova specie di Aleurodes vivente sull' olivo. Bollettino del Laboratorio di Zoologia Generale e Agraria della R. Scuola Superiore d'Agricoltura. Portici 5, 214-225.

Silvestri, F. (1915) Contributo alla conoscenza degli insetti dell ${ }^{\prime}$ 
olivo dell' Eritrea e dell' Africa meridionale Fam. Aleyrodidae. Bollettino del Laboratorio di Zoologia Generale e Agraria della R. Scuola Superiore d'Agricoltura. Portici 9, 245-249.

Silvestri, F. (1934) Compendio di entomologia applicata 1, 448 pp. Portici.

Singh, K. (1931) A contribution towards our knowledge of the Aleyrodidae (whiteflies) of India. Memoirs of the Department of Agriculture in India 12, 1-98.

Smith, I.M., McNamara, D.G., Scott, P.R. \& Holderness, M. [Eds] (1997) Quarantine pests for Europe, second edition - data sheets on quarantine pests for the European Union and for the European and Mediterranean Plant Protection Organization. 1425 pp. CAB International/EPPO, Wallingford.

Sorensen, J.T., Gill, R.J., Dowell, R.V. \& Garrison, R.W. (1990) The introduction of Siphoninus phillyreae (Haliday) (Homoptera: Aleyrodidae) into North America: niche competition, evolution of host plant acceptance, and a prediction of its potential range in the Nearctic. Pan-Pacific Entomologist 66, 43-54.

Szelegiewicz, H. (1979) Maczliki Aleyrododea. Katalog Fauny Polski, Polska Akademia Nauk Instytut Zoologii 21, 3-19.

Takahashi, R. (1932) Aleyrodidae of Formosa, Part I. Report. Department of Agriculture. Government Research Institute. Formosa 59, 1-57.

Takahashi, R. (1934) A new whitefly from China (Aleyrodidae, Homoptera). Lingnan Science Journal 13, 137-141.

Takahashi, R. (1936) Some Aleyrodidae, Aphididae, Coccidae (Homoptera), and Thysanoptera from Micronesia. Tenthredo 1, 109-120.

Takahashi, R. (1938) Notes on the Aleyrodidae of Japan (Homoptera) VI. Kontyù 12, 70-74.

Takahashi, R. (1940) A new species of Aleyrodidae from Jugoslavia. Arb. morp. taxon. Ent. Berl. 7, 148-149.

Takahashi, R. (1951) Some species of Aleyrodidae (Homoptera) from from Madagascar, with a species from Mauritius. Mémoires de l'Institut Scientifique de Madagascar (A) 6, 353-385.

Takahashi, R. (1952) Aleurotuberculatus and Parabemisia of Japan (Aleyrodidae, Homoptera). Miscellaneous Reports of the Research Institute for Natural Resources. Tokyo 25, 17-24.

Takahashi, R. (1954) Key to the tribes and genera of Aleyrodidae of Japan, with descriptions of three new genera and one new species (Homoptera). Insecta Matsumurana 18, $47-53$

Trehan, K.N. (1938) Two new species of Aleurodidae found on ferns in greenhouses in Britain (Hemiptera). Proceedings of the Royal Entomological Society of London (B) 7, 182-189.

Trehan, K.N. (1939) Studies on the British Aleurodidae. Current Science 8, 266.

Trehan, K.N. (1940) Studies on the British whiteflies (Homoptera - Aleyrodidae). Transactions of the Royal Entomological Society of London 90, 575-616.

Tullgren, A. (1907) Über einige Arten der Familie Aleurodidae. Arkiv för Zoologi 3, 1-18.

Tremblay, E. \& Iaccarino, F.M. (1978) Aleurotuba jelineki (Frauen.) per Aleurotrachelus jelineki (Frauen.) (Homoptera Aleyrodidae) su viburno. Bollettino del Laboratorio de Entomologia Agraria 'Filippo Silvestri' 35, 57-66.

Ulusoy, M.R. \& Uygun, N. (1996) Doğu Akdeniz Bölgesi turunçgillerinde potansiyel iki yeni zararli: Aleurothrixus floccosus (Maskell) ve Paraleyrodes minei Iaccarino
(Homoptera, Aleyrodidae). Türk Entomologi Dergisi 20, 113-121.

Ulusoy, M.R., Uygun, N., Kersting, U., Karaca, I. \& Satar, S. (1996) Present status of citrus whiteflies (Homoptera: Aleyrodidae) in Turkey and their control. Zeitschrift für Pflanzenkrankheiten und Pflanzenschutz 103, 397-402.

Upton, M.S. (1993) Aqueous gum-chloral slide mounting media: an historical review. Bulletin of Entomological Research 83, 267-274.

Uygun, N. \& Elekçioğlu, I.H. (1990) Doğu Akdeniz Bölgesi beyaz sinek (Homoptera, Aleyrodidae) türlerinin saptanmasi. Türk Entomologi Dergisi 14, 85-96.

Uygun, N., Elekçioğlu, I.H. \& Ulusoy, M.R. (1996) Doğu Akdeniz Bölgesi'nde saptanan yeni Beyazsinek (Homoptera, Aleyrodidae türleri. Türk Entomologi Dergisi 20, 105-111.

Visnya, A. (1936) További molytetvek köszegröl és vidékeröl. Weitere Mottenläuse aus der Umgebung von Köszeg. Folia sabariensis vasi Szle 3, 116-117.

Visnya, A. (1941a) A gigantic species of Aleurodidae (Homoptera) from greenhouse-Orchideas. Folia Entomologica Hungarica 6, 4-15.

Visnya, A. (1941b) Vorarbeiten zur Kenntnis der Aleurodidenfauna von Ungarn, nebst systematischen Bemerkungen über die Gattungen Aleurochiton, Pealius und Bemisia (Homoptera). Fragmenta Faunistica Hungarica 4 (Supplement), $19 \mathrm{pp}$.

Walker, F. (1852) List of specimens of homopterous insects in the collection of the British Museum 4, 909-1188. London.

Westwood, J.O. (1856) The new Aleyrodes of the greenhouse. Gardeners' Chronicle 1856, 852.

Wünn, H. (1926) in Elass - Lothringen vorkommende Schildlausarten. Zeitschrift für Wissenschaftliche Insektbiologie. Berlin 21, 22-28.

Zahradnik, J. (1961) Nouvelles connaissances faunistiques et taxonomiques sur les aleyrodides de la Tchécoslovaquie (Homoptera, Aleyrodinea). Acta Faunistica Entomologica Musei Nationalis Pragae 7, 61-80.

Zahradnik, J. (1962) Données taxonomiques et faunistiques sur Japaneyrodes nov. gen. similis europaeus n. ssp. (Homoptera, Aleyrodinea). Acta Faunistica Entomologica Musei Nationalis Pragae 8, 13-19.

Zahradnik, J. (1963) Aleyrodina. in Die Tierwelt Mitteleuropas (N.S.) 4, 1-19.

Zahradnik, J. (1985) La révision des aleurodes des pays Tchêques (Sternorrhyncha: Aleyrodinea) I. Věstnik Československé Společnosti Zoologické 49, 301-320.

Zahradnik, J. (1987a) Asterobemisia nigrini sp. n., un aleurode nouveau de la Tchécoslovaquie (Sternorrhyncha, Aleyrodinea). Acta Entomologica Bohemoslovaca 84, 350-352.

Zahradnik, J. (1987b) La révision des aleurodes des pays Tchêques (Sternorrhyncha: Aleyrodinea) II. Věstnik Československé Společnosti Zoologické 51, 60-80.

Zahradnik, J. (1989a) Neue funde von mottenläusen in der Schweitz (Sternorrhyncha: Aleyrodinea) III. Acta Universitatis Carolinae. Biologica 31, 355-358.

Zahradnik, J. (1989b) La révision des aleurodes des pays Tchêques (Sternorrhyncha: Aleyrodinea) III. Acta Universitatis Carolinae. Biologica 31, 407-443.

Zahradnik, J. (1991) Taxonomisches und Faunistisches über europäische Mottenläuse (Aleyrodinea). Acta Universitatis Carolinae 35, 111-118. 


\section{Appendix 1}

Check-list of whiteflies of the Macaronesian islands.

Abbreviations following each species name: A, Azores; C, Canaries; M, Madeira.

Aleyrodinae

Acaudaleyrodes rachipora (Singh)

Aleuroplatus perseaphagus Martin, Aguiar \& Pita

Aleurothrixus floccosus (Maskell)

Aleurotrachelus atratus Hempel

Aleurotrachelus rhamnicola (Goux)

Aleurotulus nephrolepidis (Quaintance)

Aleyrodes proletella (Linnaeus)

Aleyrodes singularis Danzig

Aleyrodes sp.

Bemisia afer species-group (several morphological forms)

Bemisia lauracea Martin, Aguiar \& Pita

Bemisia medinae Gomez-Menor (member of afer-group)

Bemisia tabaci (Gennadius)

Dialeurodes citrifolii (Ashmead)

Parabemisia myricae (Kuwana)

Pealius azaleae (Baker \& Moles)

Pealius madeirensis Martin, Aguiar \& Pita

Siphoninus sp./spp.

Trialeurodes ricini (Misra)

Trialeurodes vaporariorum (Westwood)

uncertain genus

uncertain genus

C

$\mathrm{M}, \mathrm{M}$

$\mathrm{M}$

$\mathrm{A}, \mathrm{C}$

$\mathrm{A}, \mathrm{C}, \mathrm{M}$

C

$\mathrm{A}, \mathrm{C}, \mathrm{M}$

$\mathrm{M}$

C

$\mathrm{M}$

$\mathrm{M}$

$\mathrm{M}$

$\mathrm{A}, \mathrm{C}$

C

C

$\mathrm{M}$

Aleurodicus dispersus Russell

Lecanoideus floccissimus Martin, Hernández-Suárez \& Carnero

$\mathrm{C}, \mathrm{M}$

Paraleyrodes bondari Peracchi

$\mathrm{C}$

Paraleyrodes citricolus Costa Lima

(Accepted 21 June 2000)

(c) The Natural History Museum, 2000 